
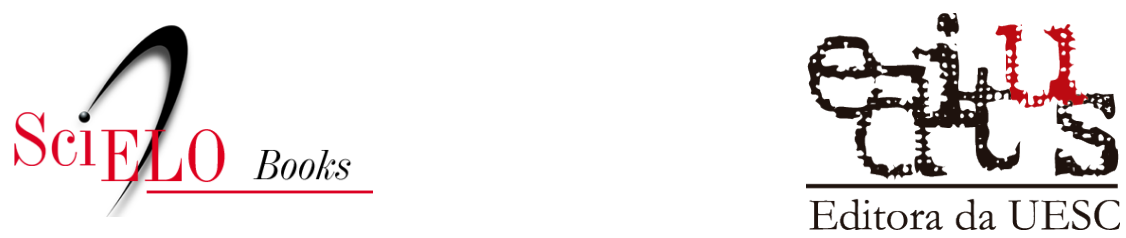

\title{
Volta miúda quilombo, memória e emancipação
}

\author{
Raíssa Félix
}

\section{SciELO Books / SciELO Livros / SciELO Libros}

FÉLIX, R. Volta miúda: quilombo, memória e emancipação [online]. Ilhéus, BA: EDITUS, 2020, 223 p. Transfluência series. ISBN: 978-65-86213-14-0. https://doi.org/10.7476/9786586213317.

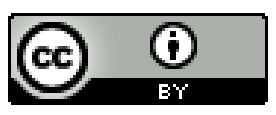

All the contents of this work, except where otherwise noted, is licensed under a Creative Commons Attribution 4.0 International license.

Todo o conteúdo deste trabalho, exceto quando houver ressalva, é publicado sob a licença Creative Commons Atribição 4.0.

Todo el contenido de esta obra, excepto donde se indique lo contrario, está bajo licencia de la licencia Creative Commons Reconocimento 4.0. 


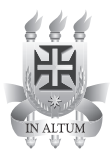

\section{Universidade Estadual de Santa Cruz}

DIRETORA DA EDITUS

Rita Virginia Alves Santos Argollo

\section{Conselho Editorial:}

Rita Virginia Alves Santos Argollo - Presidente Alexandra Marselha Siqueira Pitolli Andréa de Azevedo Morégula Carlos Pereira Neto

Dejeane de Oliveira Silva Iracildo Silva Santos

Helga Dulce Bispo Passos Luciana Sedano de Souza Lurdes Bertol Rocha Maria Cristina Rangel Maria Luiza Silva Santos Maurício Santana Moreau Raquel da Silva Ortega Sabrina Nascimento

\section{GOVERNO DO ESTADO DA BAHIA}

Rui Costa - Governador

\section{SECRETARIA DE EDUCAÇÃO}

Jerônimo Rodrigues - Secretário

UNIVERSIDADE ESTADUAL DE SANTA CRUZ

Alessandro Fernandes de Santana - Reitor Maurício Santana Moreau - Vice-Reitor

\section{Universidade Federal do Sul da Bahia - UFSB}

Reitora Joana Angélica Guimarães da Luz Vice-Reitor Francisco José Gomes Mesquita Pró-Reitor de Pesquisa e Pós-Graduação Rogério Hermida Quintella Diretor de Pós-Graduação Nadson Ressye Simões da Silva

Programa de Pós-Graduação em Ensino e Relações Étnico-Raciais - PPGER

Coordenação Geral PPGER Cynthia de Cássia Santos Barra Coordenação PPGER, campus Sosígenes Costa Eliana Póvoas Pereira Estrela Brito Coordenação PPGER, campus Paulo Freire Gilson Brandão de Oliveira Júnior

Projeto Transfluência: Ensino, Gênero, Relações Étnico-Raciais

Coordenação Editorial

Cynthia de Cássia Santos Barra Laura Castro de Araújo

\section{Comissão de Seleção de Obras - PPGER/UFSB} Apoena Dandara Silva Santos Cynthia de Cássia Santos Barra Francisco A. Nascimento Junior Francisco Antônio Nunes Neto Hamilton Richard A. F. Santos Laura Castro de Araújo Paulo César Pereira de Jesus Rebeca Valadão Bussinger Yuri Miguel Macedo 


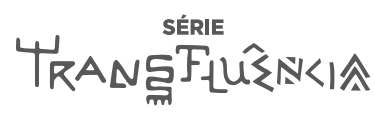

\section{VOLTA MIÚDA: QUILOMBO, MEMÓRIA E EMANCIPAÇÃO}

RAÍSSA FÉLIX

Ilhéus - Bahia 2020
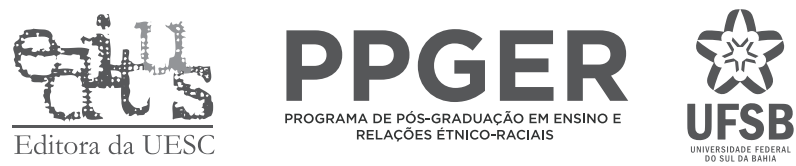
Copyright (C) 2020 by Raíssa FÉLIx Almeida BitTenCourT

Direitos desta edição reservados à

EDITUS - EDITORA DA UESC

PPGER/UFSB

A reprodução não autorizada desta publicação, por qualquer meio, seja total ou parcial, constitui violação da Lei n ${ }^{\circ}$ 9.610/98.

Depósito legal na Biblioteca Nacional,

conforme Lei no ${ }^{0}$ 10.994, de 14 de dezembro de 2004.

GERÊNCIA DE PRODUÇÃO

Sabrina Nascimento

PROJETO GRÁFICO

Lia Cunha

Tiago Ribeiro

FOTOGRAFIAS

Arquivo pessoal da pesquisadora

FINALIZAÇÃO

Deise Francis Krause

REVISÃO

Pedro de Carvalho Neto

Tess Chamusca Pirajá

Dados Internacionais de Catalogação na Publicação (CIP)

F48 Félix, Raíssa

Volta miúda: quilombo, memória e emancipação

/ Raíssa Félix. - Ilhéus, BA: Editus, 2020.

223 p.: il. - (Transfluência)

Referências: p. 197-206.

ISBN: 978-65-86213-14-0

1. Quilombos. 2. Quilombos - Bahia. 3.

Quilombolas - História - Brasil. 4. Direito Aspectos sociais. I. Título.

CDD 305

Elaborado por Quele Pinheiro Valença CRB 5/1533

EDITUS - EDITORA DA UESC

Universidade Estadual de Santa Cruz

Rodovia Jorge Amado, km 16 - 45662-90o - Ilhéus, Bahia, Brasil

Tel.: (73) 3680-5028

www.uesc.br/editora

editus@uesc.br

EDITORA FILIADA À

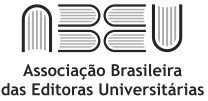




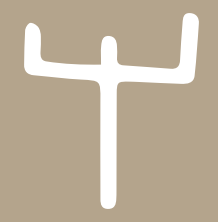




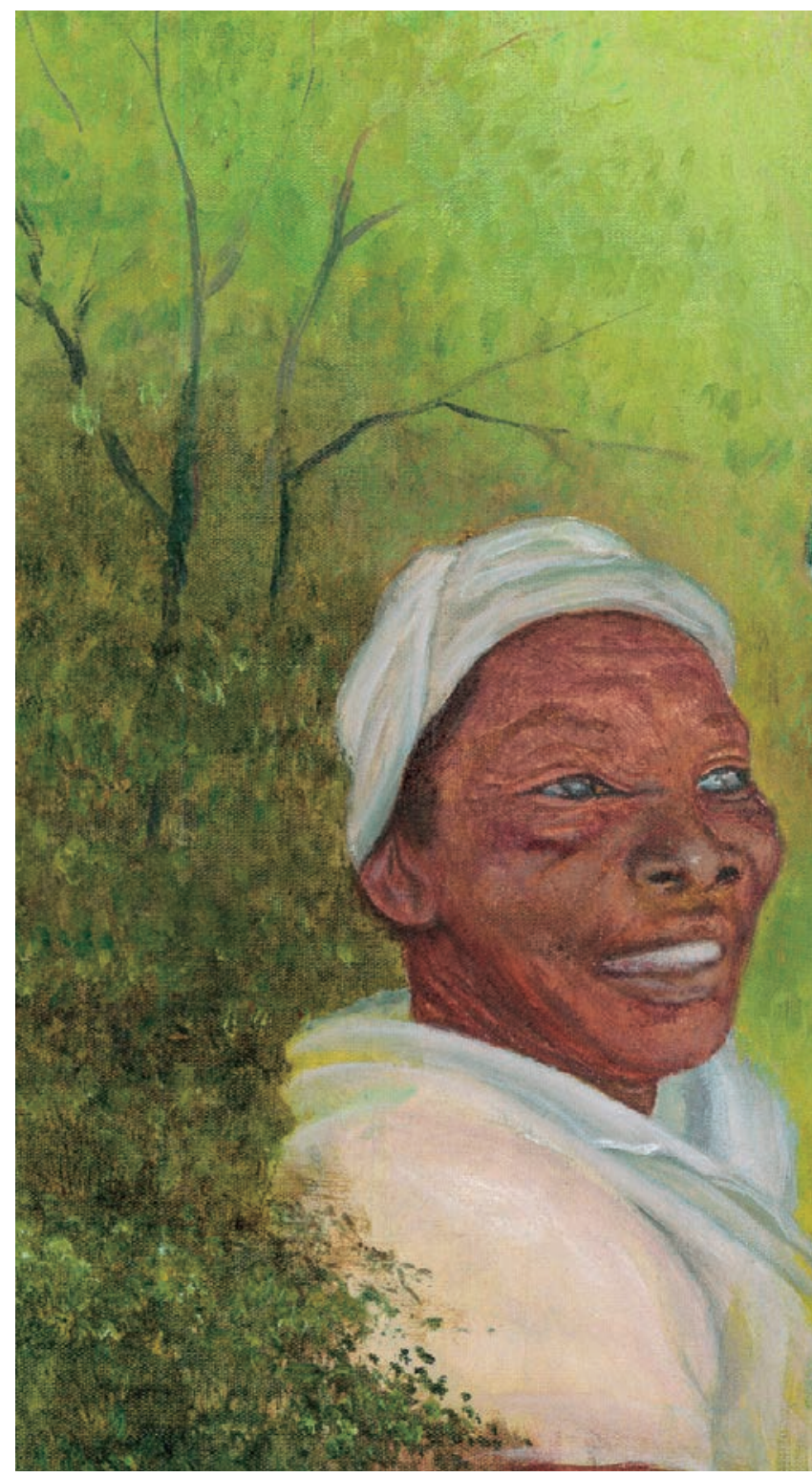




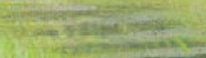

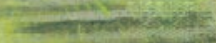

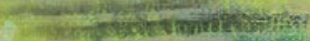

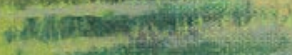

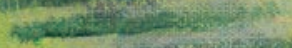

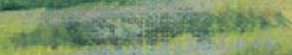

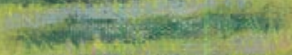

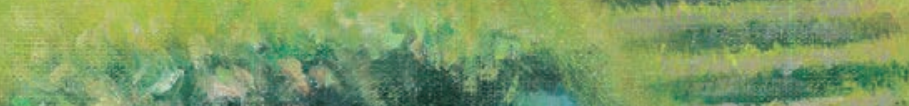

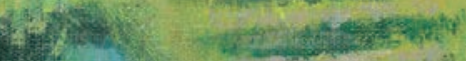

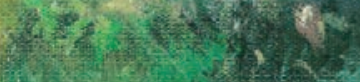
His (20.5)

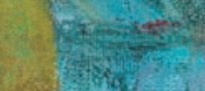
ing 4 ind git we

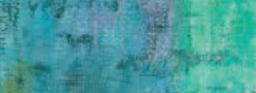

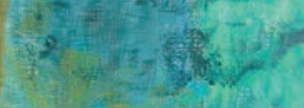

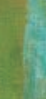
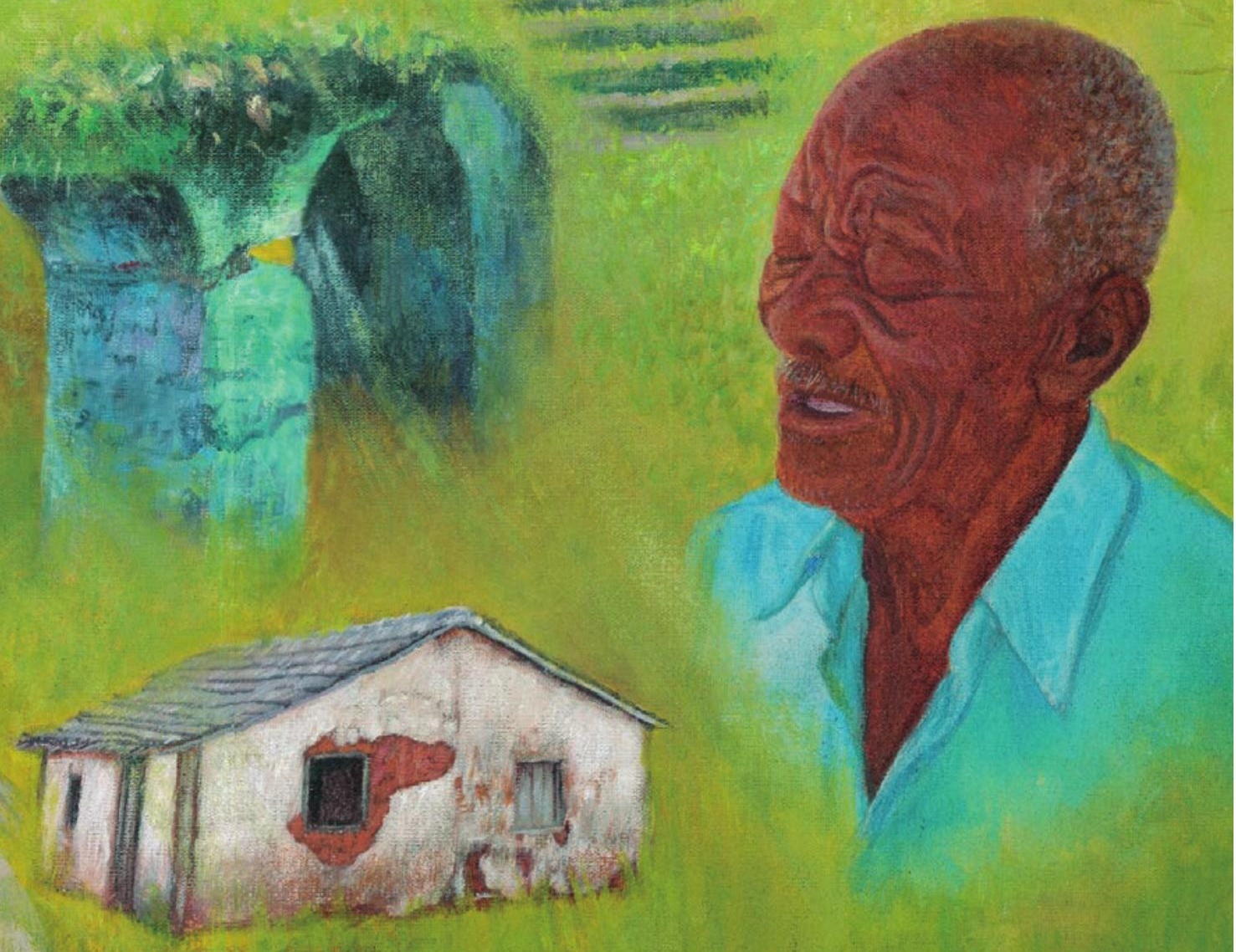

fragmento da obra de Irley de Jesus 



\section{agradecimentos}

Ao longo de muitas noites imaginei o que escreveria nesta seção, noites em que pensei se alcançaria uma boa nota no Enem, se conseguiria a única bolsa integral disponibilizada pelo ProUni para o curso de Direito, se daria conta de passar na OAB antes do término da faculdade, se conseguiria conciliar estudo e trabalho - que me ocupava sete dias por semana, desde os 17 anos -, como passaria no teste de proficiência, diante do inglês precário da escola pública, o que faria para conseguir me especializar... Vivia à caça de cursos gratuitos: fiz Libras, literatura regional, música, informática básica, italiano, participei do pré-vestibular "Alargando o funil" e do "Universidade Para Todos - UPT", na Universidade do Estado da Bahia (UNEB-Campus X). Por muitas noites repeti nomes para me lembrar de agradecer quando este momento chegasse, a finalização do mestrado e a publicação dos resultados da minha pesquisa, que marca a superação de mais um "se" e a renovação de tantos outros. Em todos esses momentos, tive sorrisos e afagos amigos.

À Comunidade Quilombola de Volta Miúda, serei para sempre grata pela acolhida, por me ensinarem a cada olhar, gesto e conversa, por me tocarem de maneiras impronunciáveis. Agradeço a acoIhida, confiança, sensibilidade e por me inspirarem e, ainda que não saibam, fortalecerem meu ânimo e fôlego para continuar lutando por justiça social. 
Mamãe, Papai e Pri e, mais recentemente, a minha maravilhosa sobrinha Raíssa - obrigada por sempre estarem ao meu lado, vocês são as razões do meu viver e a vocês devo toda e cada conquista, afinal, em nossa vida só existe "nós". É muito pouco o que poderia expressar nestas linhas, e por isso vivo em declaração constante de amor e gratidão. Tenho certeza que vocês sabem que faria tudo e qualquer coisa para vê-los felizes. Mamãezinha, obrigada por cada madrugada em que se levantava (e se levanta) para fazer café, a fim de que eu vença o cansaço e continue estudando - por estudar comigo desde pequenininha até hoje -, pelos dias lindos que vivemos em Volta Miúda, e por ser a minha assistente de pesquisa; Papaizinho, obrigada por estudar italiano comigo, todas as sextas-feiras depois do trabalho, de bicicleta ou esperando o ônibus por pelo menos duas horas para voltarmos para casa, por quase cinco anos; Pri, na verdade, eu sou a segunda melhor irmã do mundo, você é a primeira e não tem discussão, obrigada por desde sempre me defender - mesmo quando eu mesma toleraria a ofensa -, você sempre foi e é o meu exemplo, ainda quero, um dia, ser como você. Ao amor da minha vida, Dr. João Bosco Félix Bittencourt, agradeço por me apresentar há cerca de quatro anos uma dimensão inimaginável do que é ser feliz, do que é viver em paz e em cumplicidade, obrigada pelo abraço que me refugia e me fortalece, "obrigada por me amar" e por também viver os meus sonhos.

Agradeço a toda a minha família materna, tias e tios, primas e primos, por sempre estarem ao meu lado e, mesmo distantes, compartilharem cada passo e vibrarem a cada conquista que, nesta relação, se faz nossa. Declaro meu amor a vocês através de Titio Isac, irmão de papai, por compartilhar das dificuldades e promover grandes aventuras a bordo da bicicleta nas idas e vindas da escola, às sextas-feiras quando sempre havia "farrinha" na venda de doces, por se preocupar e cuidar de nós com sentimento paternal. À vovó 
Rute, declaro o meu amor e, in memoriam, registro meu amor e gratidão à Vovó Maria, que é o meu maior exemplo de sabedoria, sensatez, força e justiça - e agradeço por nos ensinar que somos mulheres para conquistar o mundo. -; a Vovô Zezinho, o meu maior exemplo de afeto e sensibilidade, e Vovô João, que ainda hoje me toca por sua fé, carinho e paciência... Obrigada.

Agradeço profundamente às amigas e amigos que compreendem a rotina complicada de quem advoga, faz mestrado, especialização e graduação ao mesmo tempo. Agradeço pelos encontros que me reoxigenam. A Aklabian Braga, meu melhor amigo desde sempre, pelas conversas e encontros em e-mails, calçadas, bancos de praça e na beira da praia, por sonharmos juntos e, juntos, participarmos da construção e vibração pela conquista de cada uma das nossas "utopias". À Manuzinha, minha pessoa, que está sempre aqui, de maneira delicada e sincera - nunca vou me esquecer daqueles lanchinhos para o intervalo dos eventos, por me mandar dormir porque estava tarde e por transgredir comigo vendo mais episódios de Grey's Anatomy do que podíamos. Agradeço muitíssimo à Amanda e Anna Luísa, sua compreensão e amizade me salvam a vida, sobretudo naqueles dias em que o cansaço bate e posso ser "apenas eu" com vocês. Eu agradeço aos amigos que estiveram presentes em cada período da minha vida, guardo-os todos numa galeria que me reflete o quão feliz fui e sou. Ao meu brother Edmilson Navarro, muito obrigada pela parceria e auxílio em todas as horas. Agradeço a Ualdo Dutra e Morau por suas contribuições a este projeto.

Agradeço também a todas as professoras e aos professores, através da minha professora da primeira série, tia Bricia Rebouças, cujo afeto tornou aquele ano tão especial, e que ainda preservo em meu coração; à Ivana Teixeira Gund, minha professora de Literatura durante o ensino médio, no Colégio da Polícia Militar - Anísio 
Teixeira, a mestre que acalentou e incentivou meus primeiros passos na escrita literária, que contribuiu de maneira muito especial e decisiva nesta caminhada, recebendo-me e guiando-me com afeto; à professora Lilian Reichert Coelho, que conheci como aluna especial na Universidade Federal do Sul da Bahia (UFSB - campus Paulo Freire), de quem compartilhei a paixão por perfis biográficos e leituras essenciais à consecução deste trabalho; à professora Maria Victoria Espiñeira que, humilde e afetuosa, me recebeu no Programa de Pós-Graduação em Ciências Sociais da Universidade Federal da Bahia (PPGCS/UFBA) e, no caminho enquanto buscávamos um cafezinho, ensinou-me a acreditar e seguir, enquanto pesquisadora, as minhas percepções e sentimentos. Agradeço à minha orientadora, Profa. Dra. Joceneide Cunha, pela confiança e liberdade, permitindo-me trajetórias ricas e inspiradoras. Agradeço a compreensão das angústias presentes no início da pesquisa, pelo empenho e confiança a fim de que o término desta pesquisa fosse possível meses antes do programado, pelos dias doados à leitura, correção e orientação entre idas e vindas entre Eunápolis e Teixeira de Freitas e apesar do cansaço da rotina. Sua orientação me garantiu um longo caminho de aprendizagens, e sou feliz por ter sido orientada por alguém que caminha em prol da justiça social e cognitiva e em defesa de um país democrático de direito.

À Universidade Federal do Sul da Bahia, campus Paulo Freire e campus Sosígenes Costa, coordenação e corpo docente e administrativo, agradeço por todo apoio nestes anos de caminhada. Agradeço aos que fazem parte do Programa de Pós-Graduação em Ensino e Relações Étnico-Raciais (PPGER/UFSB), por me proporcionarem experiências tão edificantes e oportunizarem a convivência com pessoas admiráveis e inspiradoras como o são minhas amigas e amigos colegas de curso, especialmente aos que tive mais contato, de Porto Seguro e Teixeira de Freitas. Através de Ananda 
Luz, Cristiane Meireles e Hiram Campos, pessoas doces e amigas, agradeço a todas e todos com muito carinho. Agradeço aos professores Ronie Alexsandro Teles e Fabia Barbosa Ribeiro, Geovani de Jesus e, em especial, a Gean Paulo G. Santana e Valdir Nunes pelos horizontes abertos por vossa sabedoria e conhecimento. Professor Gean, que gratidão tê-lo conhecido por intermédio das palavras, ainda nas leituras preliminares para composição deste projeto, e ter a oportunidade de fechar este ciclo com o seu olhar e afeto tão próximos e cheios de carinho.

Por fim, agradeço, a todas e todos aqueles que, antes de mim, lutaram e lutam por inclusão social, pela democratização da educação, pois eu sou fruto da força de cada um/a de vocês. E, de mãos dadas, doo-me em letras, voz e ação, para que continuemos a sonhar com uma sociedade mais justa. 

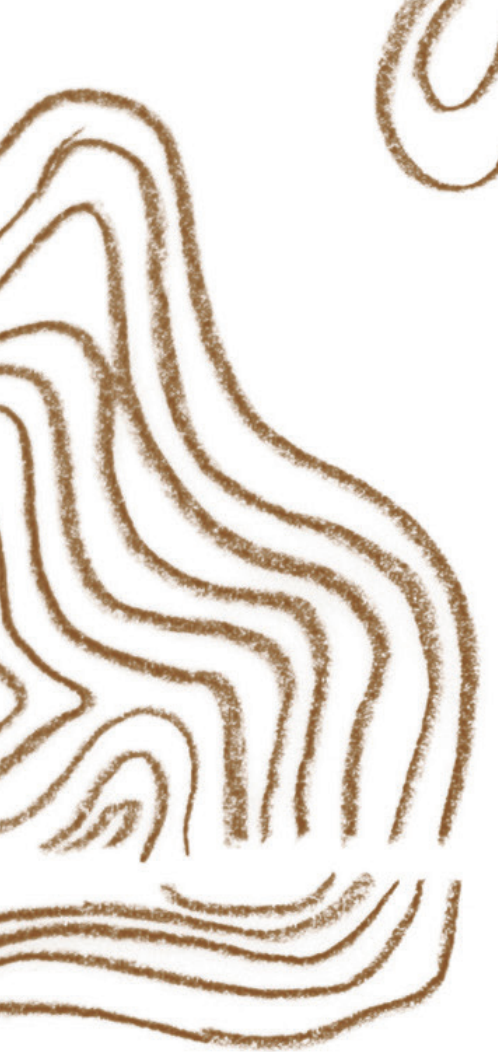


\section{sumário}

19 apresentação|Kabengele Munanga

25 Introdução

35 Perfilando a comunidade quilombola de Volta Miúda

49 Da colonialidade à emancipação: uma história possível

69 Os caminhos trilhados para a concretização do direito à memória quilombola

83 As/os quilombolas de Volta Miúda em perfil

83 Brasília Firmina

88 Manoel de Delfina

96 Domingos Serafim

101 Berta D’Ajuda

106 Santinho Brasílio

115 Miúda

119 Zelita 


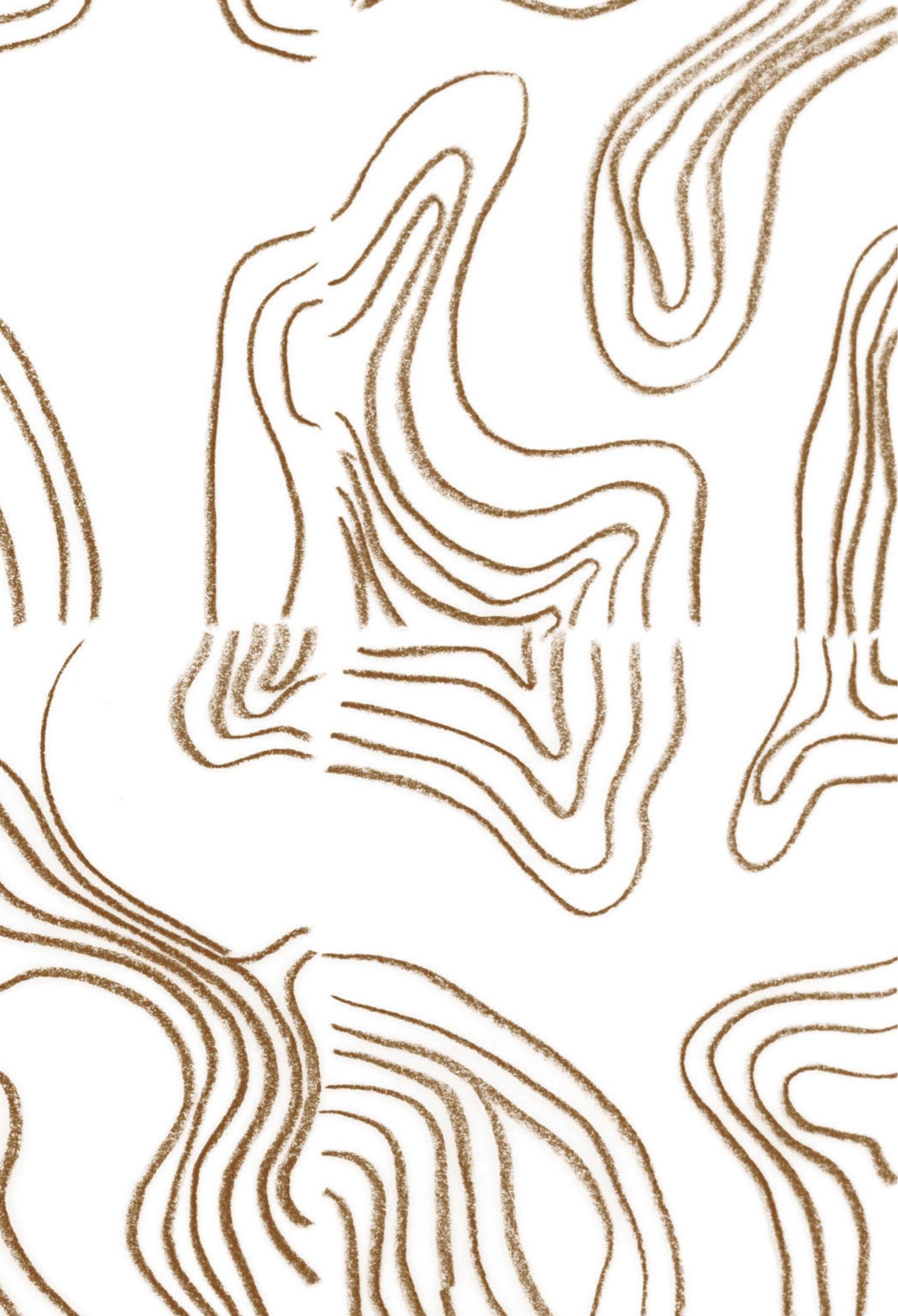


133 Domingo Antônio

137 Maria dos Reis

140 Nida

147 Da voz à letra: oralidade, ancestralidade e resistência

165 A dignificação da identidade quilombola a partir das memórias

181 Reflexões finais

191 Dicas de leitura

197 referências

209 posfácio|Cynthia Cy Barra e Laura Castro

223 sobre a autora 


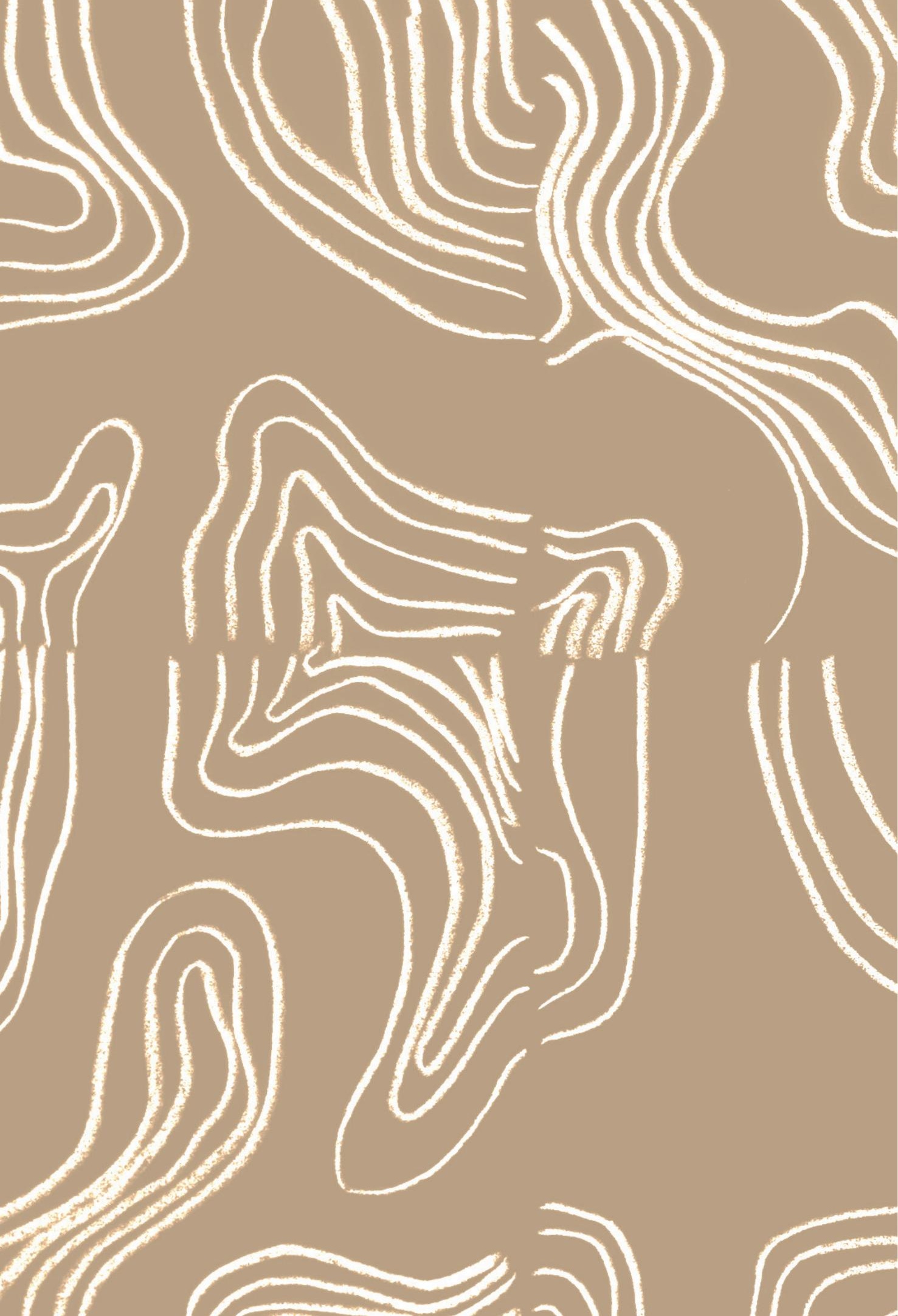




\section{apresentação}

São centenas de comunidades remanescentes de quilombos, genericamente chamadas de quilombos ou comunidades quilombolas, que pululam o Brasil do Leste ao Oeste e do Sul ao Norte. Mas de onde veio a palavra quilombo e por que as pessoas que vivem e pertencem a essas comunidades, no exemplo de Volta Miúda, são chamadas quilombolas no Brasil do século XXI? Dizer quilombo ou comunidade quilombola remete à uma identidade coletiva atribuída a essas comunidades e seus membros.

Substantiva e adjetivalmente, as comunidades e as pessoas que carregam em sua identidade as palavras quilombo e quilombola são consequentes de uma longa história de resistência cultural contra o escravismo, em defesa de sua liberdade e dignidade humana. Ou seja, a palavra quilombo é uma denominação que devemos considerar como uma identidade coletiva de todos os escravizados que fugiram das senzalas para construir novas comunidades onde poderiam viver em liberdade.

Parece-nos uma identidade atribuída pelo próprio sistema escravista. Mas, na realidade, a palavra quilombo, que é uma transformação portuguesa da palavra kilombo, certamente é de origem das línguas bantu, precisamente da língua Quimbundo 
de Angola. Ela não poderia originalmente ser atribuída pelos portugueses aos escravizados fugitivos, a não ser por eles mesmos que sabiam o que significava. Nessa língua, quilombo não significava habitação dos negros fugitivos das senzalas, mas sim uma sociedade ou organização de guerreiros.

O Brasil aboliu a escravidão em 1888, 40 anos depois da França e 24 anos depois dos Estados Unidos. Com tamanho atraso, teria sido uma abolição mais amadurecida que, infelizmente, não se concretizou, porque não houve ruptura pela incapacidade de eliminar as profundas desigualdades econômicas e sociais herdadas do sistema escravagista. Pelo contrário, produziu-se um modelo de racismo sui generis para manter o status quo. Nessa manutenção, a relação entre senhores e escravizados de ontem foi transformada na relação entre brancos e negros de hoje, uns e outros hierarquizados em superiores e inferiores.

É por isso que se costuma dizer que, depois de 132 anos da abolição da escravatura no Brasil, a Casa Grande e a Senzala ainda permanecem, mas sob nova roupagem. Os negros ainda continuam na Senzala com alguns brancos pobres da mesma maneira que, na República de Palmares, negros conviveram com alguns brancos pobres e indígenas. Eles não fazem parte da classe dominante, seja à direita ou à esquerda. Eles não se encontram no escalão superior dos empreendedores brasileiros. Não os vemos circulando representativamente nos bairros habitados pela burguesia e alta classe média brasileira. Faz apenas 20 anos que os vemos circular, embora sub-representados, nos corredores das faculdades das universidades públicas brasileiras. 
Qual é a situação dos descendentes de escravizados que viviam nos quilombos espalhados por todo o Brasil? Nem todos foram para cidades e suas periferias, pois muitos continuam a viver nos territórios e terras que foram ocupados por seus ancestrais. Territórios e terras denominados quilombos, como já foi dito. Pesquisa recente realizada pelo Centro de Cartografia da Universidade de Brasília informa que suas localizações chegam a cinco mil. Essas comunidades são diferentes umas das outras em termos de história, cultura e religião, mas todas têm problemas e dificuldades em comum: não possuem documentos de propriedade da terra de seus ancestrais que viviam da tradição oral. Para eles, não havia necessidade de provas escritas para provar que essas terras pertenciam a seus ancestrais que por elas lutaram. Até hoje eles vivem em ameaça permanente e muitos já perderam suas terras e territórios por falta de documentos escritos. Muitas entre elas não têm escolas em suas comunidades; não têm postos de saúde pública; não possuem estradas e transportes públicos que possam facilitar seus deslocamentos e contatos com a sociedade global e a evacuação do excedente de seus produtos agrícolas para os mercados locais.

É por isso que, no Brasil de hoje, todas as tendências do movimento negro defendem a ideia de uma nova abolição que viria através de políticas públicas afirmativas direcionadas, como foi o caso das cotas que facilitaram o acesso de estudantes negros e negras nas universidades públicas. A quilombagem brasileira havia conseguido minar o sistema escravista, forçando-o a fechar as portas, mas o negro continua sendo marginalizado. Isso prova que a emancipação 
pela qual ele lutou é uma realidade inacabada. Daí o sentido de ser do slogan "Aquilombar-se", que traduz a ideia da resistência permanente sem abrir mão da luta, apesar de alguns resultados obtidos com a política de cotas ou ações afirmativas.

Cada Comunidade Quilombola tem sua história diferente das outras, apesar das características históricas comuns que tentei sintetizar nesta apresentação. Sobre algumas encontram-se relatos escritos muitas vezes contados do ponto de vista do "outro", em vez de partir das narrativas dos membros vivos dessas comunidades. Narrativas construídas a partir de suas experiências de vida e da memória coletiva herdada de seus ancestrais fundadores na perspectiva de uma escrevivência, emprestando o rico conceito cunhado pela grande escritora negra Conceição Evaristo.

Como disse o sábio de Mali, Hampâté Bâ, cada ancião/ anciã que morre é como uma biblioteca viva que desaparece. Consciente dessa ameaça, Raissa Félix tenta escrever a História de Volta Miúda a partir de ricas entrevistas feitas in locu com cinco anciãs e quatro anciãos, num total de nove entrevistadas(os). Da narrativa construída a partir dessas entrevistas resulta uma hermenêutica polifônica que traz toda a história de resistência cultural da comunidade, sua visão do mundo, da humanidade e do Brasil e seus problemas e dificuldades num universo racista e capitalista brasileiro, onde suas vozes não são escutadas e suas dificuldades e problemas não são contemplados, deixando claro que eles continuem, apesar da abolição formal, a aquilombar-se. 
O desenvolvimento de sua economia de subsistência, numa terra coletiva e não uma propriedade individual, terra sempre cobiçada pelos interesses alheios, não pode ser um projeto enlatado provindo dos órgãos públicos ou pensado numa visão paternalista sem respeitar suas próprias vozes, suas experiências e suas necessidades. Todas essas questões que o artigo 68 da Constituição de 1988, que garante aos remanescentes das comunidades dos quilombos o direito à propriedade de suas terras, não resolve efetivamente, correm em filigrana, não apenas em termos descritivos, mas também nas ricas especulações tanto filosóficas quanto político-ideológicas de Raissa Félix. As dezenas de ricas ilustrações, em termos de fotografias e outras imagens que compõem o livro, oferecem uma outra leitura e uma prova testemunhal de sua penetração no universo da pesquisa. Como diz um ditado africano, "enquanto os leões não tiverem seus historiadores, a história da caça continuará a ser contada pelos caçadores que sempre se vangloriarão". Esta preocupação permeia todas as páginas deste livro que Raíssa Félix oferece afetuosamente a seus leitores, entre os quais me inclui.

\section{Kabengele Munanga}

Setembro de 2020 



\section{1}

\section{introdução}

A palavra escrita é esta ferramenta que nos permite trazer pensamentos ao mundo, sempre incompleta, hábil a correções e dotada de intencionalidades. Esta é uma parte minha que vem se construindo há muito tempo, pelos caminhos trilhados por aquela/es que me compartilharam a vida e por tanta/os outra/os com quem irmana a minha existência, sempre ávida por entender o mundo, sensível e ainda mais.

Decerto que o caminho se faz sempre, ainda que não se esteja atenta/o para percebê-lo. E, ao fazer um exercício retrospectivo, percebo que a lembrança sempre foi, para mim, um aspecto essencial para que me sentisse "gente". Das caixas com itens da infância, cartas e fotografias dos meus pais e avós, erigi. Percebendo ausências de uma história que excede a minha trajetória individual, reverti os sentimentos de espanto e tristeza na busca por uma consecução memorial hábil a construir-me a dignidade - a mim, que não me via dissociada dos meus avós indígenas e violentados, dos meus avós explorados nos campos de trabalho rurais, que me encontrava neste limbo que é ser "parda". 
Este livro é uma - das muitas perspectivas possíveis de - apresentação de um ciclo de vida iniciado antes mesmo do Mestrado Profissional na Universidade Federal do Sul da Bahia (UFSB), campus Paulo Freire, período em que de fato desenvolvi esta pesquisa. Do primeiro livro que li, apresentado por meu pai, numa antiga versão, guardo o apreço com as palavras. O velejador Amyr Klink (2011, p. 9), por meio de um perfil, encantou-me com a habilidade que têm as palavras de ensinar, despertar e, como acredito veementemente, transformar-nos e transportar-nos a outros lugares de senciência. Fê-lo descrevendo-me Rosa, um caso de amor. Uma canoa.

Durante os primeiros semestres da graduação em "Direito" - termo que hoje incomoda - descobri o "direito à memória e à verdade", pois o seu reverso, defendido por alguns "doutrinadores" - outro termo incômodo - nunca me fez sentido, o "direito ao esquecimento", que, inobstante às acepções em outras áreas do conhecimento, como a História e a Psicologia, sugere, no âmbito jurídico, a legitimação ao silenciamento. Que é esquecer, senão apagar a identidade por essência?

A trajetória nos bancos de uma faculdade branca e elitizada, mantida por uma irmandade católica, deu-me a técnica e a capacidade para entender e explicitar que inexistem direitos individuais, sociais, civis ou políticos sem a tutela primeira à história dos sujeitos. Eu, egressa da escola pública e bolsista integral pelo Programa Universidade Para Todos (ProUni), que assistia ao discurso incoerente sobre a dignidade humana, tornei-me advogada, graduei-me, então, vocacionada a evidenciar as fraturas de um sistema 
que, de inúmeras maneiras, reprime, aprisiona e mata. Desde cedo entendi que a deturpação histórica é também uma forma de matar, como diria o mestre Abdias Nascimento (2019, p. 187).

O direito à memória levou à leitura de Jacques Le Goff (2003), o qual ensina que o silenciamento histórico - ou seja, quando a oportunidade de conhecer a história é tolhida, seja ela individual e/ou coletiva - faz-se uma ferramenta eficaz para o controle e alienação identitária. Em outras palavras, esse silenciamento forçado que distancia os indivíduos das suas origens perpetua o processo de dominação. Afinal, que era eu, não branca e não preta, autodenominada parda, e de que dignidade dispunha se me faltava conhecimento sobre as minhas origens, étnicas e territoriais? Percebi-me, em grande parte, uma lacuna.

De interrogação em interrogação, senti-me responsável pelo desconhecimento sobre a minha história, senti-me responsável por, durante a maior parte da minha breve existência, ignorar a riqueza histórico-étnico-cultural do meu lugar - incomodei-me com o silenciamento e fui à procura de respostas capazes de preencher de sentido o gentílico que me acompanha. Teixeira de Freitas é uma cidade localizada no Extremo Sul do Estado da Bahia, foi criada por meio da Lei $n^{\circ}$ 4.452, de 9 de maio de 1985 (BAHIA, 1985), a partir do desmembramento dos municípios de Alcobaça e Caravelas, de forma que, apesar das terras contíguas, somos distanciados por uma limitação territorial que parece dissociar a nossa origem - tão entrelaçada. Sentia-me, também, parte daquelas histórias. 
1. A Fundação

Cultural Palmares

(2020) já certificou como remanescentes quilombolas as seguintes comunidades na região extremo sul da Bahia: Volta Miúda,

Naiá e Mutum, do município de Caravelas, por meio da Portaria n. ${ }^{\circ} 26 / 2005$; Helvécia (Portaria n. ${ }^{\circ} 7 / 2005$ ) e Rio do Sul e Cândido Mariano, no município de Nova Viçosa, por meio da Portaria n. ${ }^{\circ}$

26/2005; e Vila Juazeiro no município de lbirapuã, por meio da Portaria n. ${ }^{\circ}$ 185/2009.
Lendo minha trajetória a partir de outro ângulo, aos 17 anos, quando comecei a trabalhar como revisora e repórter em um jornal local, tive meus primeiros contatos e ciência sobre a existência de comunidades remanescentes quilombolas na região do extremo sul da Bahia ${ }^{1}$. Helvécia era uma incógnita que testificava a minha ignorância, e esta ignorância era uma agressão a mim, às crianças que via crescer, como eu, educadas em instituições escolares públicas incompetentes ao exercício libertário que, penso, deveria ser o processo de ensino-aprendizagem. Como assevera Kabengele Munanga (2015, p. 22), "o reconhecimento das identidades particulares no contexto nacional se configura como uma questão de justiça social e de direitos coletivos", é a pedra angular da dignidade humana. Portanto, ignorar, consentir com a parcialidade da História, é agredir àqueles cujo sangue corre em nossas veias ou em nossas mãos, pois não há neutralidade possível ante a barbárie.

Das notícias e entrevistas à leitura de trabalhos de professoras e professores da Universidade do Estado da Bahia - Campus X me propus a pesquisar a comunidade de Helvécia. Iniciei a trajetória conversando e aprendendo com esses mestres, estive com o professor doutor Valdir Nunes dos Santos numa oportunidade em que realizou uma oficina de literatura na Escola Municipal João Martins Peixoto, em Helvécia, que me alertou sobre a responsabilidade da tarefa a que me propunha, sobre os vínculos que ensejaria e os sentimentos que me cativariam.

Ao professor doutor Gean Paulo Gonçalves Santana, agradeço por ter me despertado a olhar além. Foi seguindo a sua sugestão que, já depois da aprovação na seleção do 
Mestrado, realizei incursões em Helvécia e em outras comunidades quilombolas da região, que me levaram a desbravar e fixar o âmbito da pesquisa na Comunidade Quilombola de Volta Miúda, município de Caravelas-BA. E isto se deu num processo de identificação com os moradores locais, pela proximidade territorial que me informa um vínculo pretérito com as mesmas terras onde nasci e habito, e em função da necessidade de contribuir com a produção científica com aquela comunidade.

Ingressar no mestrado foi a oportunidade para a minha busca em fomentar a comunicação e emancipação de conjuntos culturais menosprezados (MUNANGA, 2015), numa perspectiva multicultural, em colocar-me à disposição da resistência e da preservação da(s) história(s). A limitação da educação escolar e o alijamento da participação e vivência coletivas vitimam individualidades cujas identidades são subalternizadas em função de padrões que representam estereótipos de dominação, que Ihes imputam subserviência e inaptidão a ocupar este mesmo lugar referencial. Aqui, falo da violência estrutural e sistêmica que, secularmente, mitiga a dignidade e liberdade das negras e negros e seus descendentes. Da colonialidade que escarifica o sujeito: arranca- Ihe sua história, sua religiosidade, sua sensibilidade, tenta apaziguá-lo desumanizando-o. É sob a sede deste renascimento que se concebe o presente livro, um instrumento, ferramenta que se utiliza da voz para fazer ciência, da experiência para sensibilizar, da memória para alimentar a compreensão de uma alternativa decolonial para a vida.

Chico César, numa de suas canções, poetiza: “caminho se conhece andando, então vez em quando é bom se 
perder... Perdido fica perguntando, vai só procurando e acha sem saber" (CÉSAR, 2008). Esta letra cai bem à leitura deste livro. Dirigi até Volta Miúda, apresentei-me e a meus objetivos, por aquelas pessoas fui recebida com abraço. Tive longas e adoráveis conversas com amigas e amigos, e o que trago aqui são traços de personalidades riquíssimas, inteligentes, sensíveis e perspicazes - quilombolas que existem e resistem. Os perfis biográficos que aqui trago são retratos escritos por mim a partir das prioridades e autorretrato que cada uma das entrevistadas e entrevistados me apresentaram. Ouso dizer que este livro não é meu, mas nosso. Ao delinear identidades, saberes e memórias das anciãs e anciãos de Volta Miúda, falo sobre afrodescendência, sobre seres quilombolas e liberdade, e, nestas linhas também gravei parte de mim, que serei, para sempre, grata por este encontro - com eles e comigo mesma.

Um percurso de apenas cerca de 40 minutos a partir da minha casa e que me levaria a um universo inimaginável. Volta Miúda me fez revolucionária, porque me fez sentir. Relatar esta caminhada nada mais é do que explicitá-la a partir de um ponto de vista possível. E há muitos. Conceber e internalizar a ideia desta multiplicidade, em contraponto ao vício da dicotomia excludente, já é, em si, um resultado deste percurso. Assim como elucidar o não contado, abstrair, com a permissão dos sujeitos daquela comunidade, e a partir da ausculta das suas vozes, aspectos históricos e culturais dissonantes da linguagem moderna-colonial-capitalista.

Busca, afeto, encontros, descobertas, reflexões e desconstruções, ingredientes desta aventura que é construída com anciãs e anciãos da Comunidade Quilombola de 
Volta Miúda, localizada no Extremo Sul da Bahia (Caravelas/ BA). Com a sua licença, imergi nas suas histórias, condensando-as no formato de perfis biográficos, inspirados no jornalismo literário, com textos breves, mas com vocação à profundidade. As preciosidades de longas e admiráveis horas de diálogo que, agora, rompem os limites de Volta Miúda, em prece.

Conceber é esta palavra que aduz criação, compreensão, que remete à geração humana. A concepção deste trabalho alude à sede de renascer que o motivou. Pois é precedido de inconformidade, irresignação, busca, trata-se do reflexo do não lugar que indeterminava a identidade da autora. Se cores não cabem ao seu fenótipo, o ser não branca e não preta determinava-Ihe o limbo. As respostas prontas, mitos, eram ineptas a explicar à mestiça a composição cênica da sua liberdade. E, assim, o exercício do sentir se fez prática decolonial ${ }^{2}$ e a escuta dos mais velhos um instrumento guia para o encontro do próprio ser. Este ser dissonante da coisificação e mercantilização da vida e relações humanas, que advoga por uma liberdade - esta utopia que está lá no horizonte - de formar-se, comportar-se, de sentir. Sob o lume das memórias busquei fazer-me gente.

Ao ser apresentado como uma proposta de humanização, este livro deve ser lido como um instrumento que convida à decolonização da vida. A autoria se constrói de forma implicada aos sujeitos de pesquisa, ao passo em que é um questionamento à mácula da colonialidade presente na formação e no Estado brasileiro, no sistema formal de Educação, nos instrumentos de produção da Ciência... Esta é uma narrativa construída sobre e a partir de histórias individu-
2. A decolonização aspira romper com a lógica monológica da modernidade, e se estabelece como um campo dialógico, voltado a pensar a modernidade/ colonialidade de forma crítica, desde posições e de acordo com as múltiplas experiências de sujeitos que sofrem de distintas formas a colonialidade do poder, do saber e do ser (MALDONADOTORRES, 2007, p. 162). 
ais que se interconectam, que desafiam a modernidade e os seus influxos tão diversamente opressores.

Assim, no Capítulo 2, leitoras, leitores e leitorxs serão apresentadas/os/xs à Comunidade Quilombola de Volta Miúda. O capítulo seguinte conduzirá à reflexão sobre o estado de colonialidade da nação brasileira e o papel do direito e do conhecimento no processo assimilacionista e negacionista das plúrimas identidades que conformam o povo. No Capítulo 4, participo os caminhos metodológicos utilizados com vistas à concretização do direito à memória coletiva dos quilombolas de Volta Miúda, passando, no Capítulo 5, à exposição das vozes alinhavadas em perfis biográficos. Nos Capítulos seguintes, 6 e 7, analisaremos a retomada da oralidade, seu caráter ancestral e a sua pujante resistência, e a dignificação da identidade quilombola a partir das memórias de Volta Miúda.

Grata aos que me antecederam e aos que virão, desejo a todas, todos e todxs uma feliz leitura. 
豆 



\section{Perfilando a comuni- dade quilombola de Volta Miúda}

A Comunidade Quilombola de Volta Miúda está localizada no Extremo Sul da Bahia, no município de Caravelas, que possui população estimada em 22.093 (vinte e duas mil e noventa e três) pessoas, conforme dados do Instituto Brasileiro de Geografia e Estatística (IBGE), ano de referência 2020 (BRASIL, 2020a). Além de Volta Miúda, o município possui outras duas comunidades reconhecidas como "remanescentes quilombolas", pela Fundação Cultural Palmares, Naiá e Mutum. Conforme o censo de 2010, a população negra é marcante no município, os negros (pretos e pardos) estão em maioridade numérica, aproximadamente $84 \%$ (oitenta e quatro por cento) da população do município (BRA$\mathrm{SIL}, 2010$ ), sendo que, atualmente, $47,2 \%$ (quarenta e sete vírgula dois por cento) da população total reside na zona rural (BRASIL, 2020a).

Os indicadores demográficos são explicados pela origem histórica da região. Em 25 de novembro de 1808, Dom 
João VI publicou Decreto permitindo a concessão de terras aos estrangeiros residentes no Brasil, como estratégia de povoamento e defesa, por meio da formação de colônias agrícolas, com incentivos à imigração. A Colônia Leopoldina foi a primeira a ser fundada na Bahia, em 1818, em Villa Viçosa, por colonos alemães e suíços.

A Colônia Leopoldina ficava situada no município de Vila Viçosa, atual Nova Viçosa, pertencente à comarca de Caravelas, no Extremo Sul da Bahia. A freguesia de Nova Viçosa foi criada em 1720, na foz do rio Peruípe, com o nome de Arraial de Campinho do Peruípe, para abrigar portugueses e índios catequizados. Foi elevada à categoria de Vila em 1768, com o nome de Vila Viçosa, e mais tarde, em 1775, ao nível de município, em território desmembrado de Caravelas. (CARMO, 2010, p. 15).

O regime escravista estava presente em toda a Colônia Leopoldina, cujas fazendas utilizavam a mão de obra escravizada africana e seus descendentes para o cultivo das terras, especialmente o café, à margem do Rio Peruípe, chegando à seguinte proporção:

Apenas uma propriedade familiar possuía mais de cem escravos em 1840: os irmãos Ernesto e Francisco Krull. Além dos irmãos Krull, os maiores proprietários de escravos na época eram João Martinho Flach, com 96 cativos, e Augusto de Coffrane, com 70. Grande parte deles (19 proprietários), apesar de não contar com um vasto número de trabalhadores à sua disposição, tinha uma posse considerada grande, acima de 20 escravos; 15 lavradores tinham uma posse média, entre 5 e 19 escravos. A média de escravos por lavrador era alta: 18,5, mas certamente não representava a realidade de todos os proprietários. (CARMO, 2010, p. 41). 
A proibição do tráfico de africanos escravizados deu-se em 1850, por meio da Lei $n .^{\circ} 581$, e contribuiu a que a procriação e, até, formação de famílias entre escravos fosse incentivada (CARMO, 2010, p. 31) pelos colonos. Volta Miúda possui uma relação íntima com outras comunidades além das citadas, como os quilombos de Helvécia, Rio do Sul e Cândido Mariano, pertencentes ao município de Nova Viçosa, presentes nas narrativas em que se estendem as relações sociais e familiares.

Volta Miúda era o nome dado a uma das fazendas da Colônia Leopoldina, de propriedade de Luiz de Jouffroy, já em funcionamento em 1840 e que, entre 1860 e 1888, contava com quarenta e nove escravos (CARMO, 2010, p. 104128). Declarada a abolição, ante a falta de perspectivas dos libertos, alguns permaneceram na região da ex-colônia Leopoldina, outros, foram alforriados no período de iminência da abolição, e, excepcionalmente, contaram com o auxílio dos senhores para a vida em liberdade. Como foi o caso de pessoas citadas por Carmo:

\footnotetext{
Floriano, Cecília, Paolo, Luis Pombal, Aninha, Benedito Pombal, Theodoro, Delfina, Alexandro, Conrado, Mariana, Serafim, Roza, Aleixo, Ermelinda, Bibiana e seus três ingênuos, Alexandrina e seus dois ingênuos, e Sophia com seu filho recém nascido. Todos eles foram libertos por Augusto Beguim em 1881, e após o fim do inventário deste senhor em 1888 , cada um recebeu $176 \$ 444$ mil reis. (CARMO, 2010, p. 81).
}

Manoel, Joaquina, Josefa são outros nomes de escravizados que aparecem nos registros do Arquivo Público do Estado da Bahia (APEB), na seção Judiciária, nos Inventários 
3. Em dissertação apresentada ao curso de mestrado em História Social, da Faculdade de Filosofia e Ciências Humanas, da Universidade Federal da Bahia, intitulada

“Colonização e escravidão na Bahia: a Colônia Leopoldina (1850-1888)", no ano de 2010.

das posses e propriedades dos colonizadores e Processos crime, analisados por Alane Fraga Carmo ${ }^{3}$ (2010). Nomes que se repetem nos diálogos com negras e negros, anciãs e anciãos, do quilombo de Volta Miúda, e que também se chamam Manoel, Joaquina, Josefa, Cecília, Benedito, Delfina, Serafim e Aleixo, uma possível referência aos ancestrais que ali viveram.

As vivências de/em Volta Miúda evocam sentidos particulares de vida, que dissonam dos princípios da política colonial-moderno-capitalista que engendram os caminhos da mercadoria. Compartilhar as experiências é participar e, ao mesmo tempo, promover a humanização dos sujeitos imbricados na relação dialógica. Domingos Serafim fala sobre esta dimensão da oralidade informando também que a preservação particular do seu bom humor é um dos aspectos que lhe garantem a vida: "Tenho meu respeito com quarquer um, mas também se a gente não fizer graças morre à toa, viu?" (9 de junho de 2018). A escuta edificante necessita do desprendimento de conceitos prévios, não apenas em relação aos sujeitos em questão, mas às pré-concepções sobre os significados da vida.

\footnotetext{
A tradição oral é a grande escala da vida, e dela recupera e relaciona todos os aspectos. Pode parecer caótica àqueles que não lhe descortinam o segredo e desconcertar a mentalidade cartesiana acostumada a separar tudo em categorias bem definidas. Dentro da tradição oral, na verdade, 0 espiritual e o material não estão dissociados. Ao passar do esotérico para o exotérico, a tradição oral consegue colocar-se ao alcance dos homens, falar-lhes de acordo com o entendimento humano, revelar-se de acordo com as aptidões humanas. Ela é ao mesmo tempo religião, conhecimento, ciência natural, inicia-
} 
ção à arte, história, divertimento e recreação, uma vez que todo pormenor sempre nos permite remontar à Unidade primordial. (HAMPÂTÉ BÂ, 2010, p. 169, grifos meus).

Memória e presente, lembrança e vida são indissociáveis. Integrar-se à Volta Miúda exige um processo de desconstrução do ouvinte/leitor e da sua abertura à compreensão de mundo pautada em princípios que desprivilegiam - capital, o acúmulo de riquezas, a produtividade do ser, a velocidade, a privacidade como dogma absoluto, os critérios hierárquicos da sociedade moderna. Ao finalizar suas ponderações acerca da tradição viva, Hampâté Bâ cita Tiemo Bokar, o sábio Bandiagara, "a África dos velhos iniciados avisa ao jovem pesquisador: 'Se queres saber quem sou, / Se queres que te ensine o que sei, / Deixa um pouco de ser o que tu és/ E esquece o que sabes'" (HAMPÂTÉ BÂ. 2010, p. 214). Acessar as memórias, experiências e histórias da comunidade exige a criação de pontes para que este encontro seja possível, sendo a principal manter-se sensível, a fim de que, no processo de desfazimento do ser que escuta, perceba-se a amálgama que conforma o ser e o mundo, o sentimento e a vida, o indivíduo e a comunidade, passado e presente como intercâmbio contínuo e indissociável da substância humana.

Este exercício se coaduna com o alerta enunciado no âmbito das discussões teóricas sobre a colonialidade enquanto violência epistêmica. Conceber ciência a partir da oralidade, ou melhor, compreender que a oralidade é ciência, fá-la instrumento de combate às opressões e desigualdades - interpretadas pela lógica colonialista como sinônimos de desenvolvimento. As subalternidades, individualidades que, 
pelo modo particular de sentir e viver, têm sua humanidade negligenciada pelo poder estabelecido, são escarificadas quando lhe vetam a continuidade e o exercício de suas idiossincrasias. A colonialidade é um sistema de práticas e princípios que, na manifestação da inépcia do sistema político que a sustém, reduz experiências externas ao limite da sua própria estupidez, por, pelo menos dois motivos possíveis, não as compreender ou por reconhecer o potencial político libertário da sua razão coexistencial.

O fazer científico que não se coloca à disposição das sociedades democráticas, cooperativas e fraternais com economias naturais, harmoniosas e viáveis, é vassalo das "sociedades esvaziadas de si próprias, de culturas espezinhadas, de instituições minadas, de terras confiscadas, de religiões assassinadas, de magnificências artísticas aniquiladas, de extraordinárias possibilidades suprimidas" (CÉSAIRE, 1978, p. 25). Colocar-se à disposição daquelas sociedades, descoIonizar, de acordo com Maria Paula Meneses, implica

abrir espacio a otros saberes secuestrados, condición para ampliar el rescate de la historia, democratizándola (Meneses, 2014). Los abordajes contextuales, los saberes em red, confluyen para ampliar el saber acerca del mundo a partir de las comunidades y para las comunidades, superando la objetificación y subalternización del otro/de la otra. Estas experiencias que se distancian de la construcción objetificada del saber (la colonialidade del saber, de la que habla Quijano, 2000), acentúan la importancia de la producción de saberes de forma dialógica y autorreflexiva, basadas en prácticas concretas. (MENESES, 2016, p. 17). 
O sociólogo Boaventura de Sousa Santos (2009, p. 30-31) prolatou o conceito de linhas abissais como marcos invisíveis que condicionam individualidades não hegemônicas a um limbo existencial, capitaneado pelo direito e conhecimento modernos, que só pode ser rompido com o processo de crítica e desconstrução dos parâmetros sociais naturalizados. Importante observar que a linha impõe a naturalização das práticas sociais e, mesmo no curso de conquistas, quando o processo impactante é ignorado, projeta-se o estado atual como inicial de forma a incorporar-se à conquista, desmobilizando a memória das lutas. Prejudica-se o processo de reconhecimento no (e do) percurso à conquista.

Ultrapassar o ponto abismal significa, portanto, refletir sobre a razão e estado a quo, compreendendo-o numa perspectiva cosmológica, assim como o processo de descoIonização e emancipação, como um todo indissociável social e historicamente. A resiliência das subalternidades se dá pela consciência viva da sua ancestralidade coexistente ao fecundo processo de transformação, que absorve os influxos do meio, sem modificar sua essência, na verdade, reconfigurando-se para possibilitar a continuidade - processo de ressignificação que Antônio Bispo (2015, p. 95) refere-se na sua análise sobre as denominações dos povos contra colonizadores. Para ir além dos estigmas, o caminho metodológico da história oral adequou-se à busca de conhecer quem são os sujeitos de Volta Miúda, os traços culturais afrodescendentes que os conformam, assim como os marcos que são, para eles, significativos para a compreensão de si mesmos e da história da comunidade. 
No mês de março de 2018, encontrei-me, em Teixeira de Freitas, com o presidente da Associação de Produtores Remanescentes Quilombolas de Volta Miúda - Caravelas/BA (APRVM), Fábio Pinheiro Leocádio, que me orientou o caminho até a comunidade: "Vai direto em Maria Mil Réis, lá na frente é só virar à esquerda". E fui. Acompanhada por minha mãe, uma Maria que se chama "Cal", minha genitora que, quando pequena, me ensinou (e ensina) o que há de mais precioso no mundo: sentir.

A primeira impressão sobre a comunidade - composta por cerca de 120 famílias, como me informara o presidente da Associação - ratificava o que ouvira em manifestações nas ruas, nas conversas entre a militância, a Volta Miúda estava escondida num caminho que se alongava, tristemente, pela paisagem: campos cobertos de eucalipto, onde se variava apenas a etapa do plantio.

Lá na frente, após algumas curvas e duas ladeiras em estrada de chão, encontramos casas e a Escola Municipal Dr. Sócrates Ramos. Minha primeira parada. Chegar, me apresentar, falar sobre a motivação da visita, explicar os objetivos: esses foram os passos iniciais que tomei para estabelecer contatos em Volta Miúda. No primeiro dia, cheguei pouco antes do término da aula, a professora B. (E. M. do V.) terminava de aplicar a lição a uma das duas turmas multisseriadas da escola e após, recebeu-me amistosamente. Ela era responsável por ensinar os 15 estudantes do primeiro e segundo anos, - visto que não havia estudantes matriculados no terceiro ano -, e o professor J. F. F, na outra sala, aos 13 estudantes do quarto e quinto anos - perfazendo um total de 28 crianças, com faixa etária dos 4 aos 13 anos - esta turma passou a ser acompanhada pela professora L. R. P. 


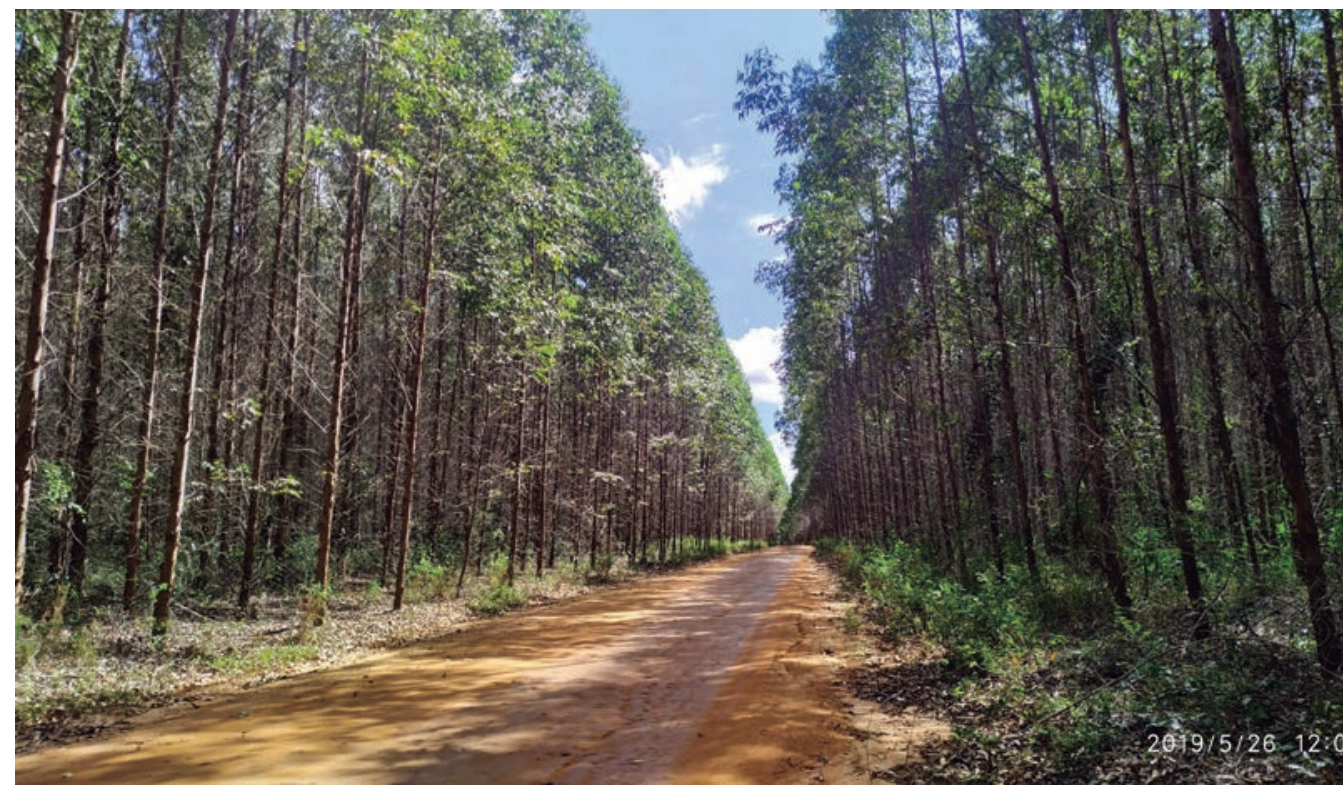

1 - Estrada que

leva à Comunidade

Quilombola de Volta Miúda (2019).

A escola está vinculada à Escola Municipal Princesa Izabel - título, no mínimo controverso -, que funciona no distrito de Juerana, aproveitando-Ihe toda a estrutura administrativa, inclusive Plano Político Pedagógico, de forma que inexiste uma educação escolar quilombola ${ }^{4}$. Além dos dois professores, a unidade contava com uma auxiliar de serviços gerais, A. P. A. S, que é da comunidade e reclamou sobre a falta de emprego, que acaba expulsando os moradores da localidade cercada por plantios de Eucalipto.

4. Também realizei um estudo sobre os livros paradidáticos de História utilizados na Escola de Volta Miúda formatado no trabalho intitulado "Livro didático e o ensino de história: perspectivas de (des)colonização na comunidade quilombola de Volta Miúda",

apresentado no Encontro Estadual de História da Associação Nacional de História Seção Bahia (ANPUHBA), em 2018 (FÉLIX, 2018). 
A professora B. me apresentou àquele que viria a ser o meu primeiro entrevistado, Manoel Reis, e citou outros moradores com quem também poderia conversar. $O$ encontramos em casa, mão na cintura, voz macia e firme, um homem de 71 anos que se apresenta como "Manoel de Delfina", esta, sua mãe. Ao Ihe explicar o que fazia ali, Seu Manoel me disse instantaneamente: "Minha bisavó era dos escravos; minha mãe nasceu da minha avó Joaquina no dia em que libertaram os escravos".

Após visitas à escola, conversas com funcionários e estudantes, segui até Volta Miúda no dia 12 de abril de 2018, com a missão de reencontrar com Seu Manoel e estabelecer novos contatos. E, assim, depois de conhecer Zelita, sua esposa, fui batendo à porta de Berta e Cassemiro, Domingos Serafim, Miúda, Santinho... Nesses encontros, chamou-me atenção o diálogo inicial com as mulheres que foi, geralmente, precedido de falas como "eu não sei falar", "eu não sou boa nisso", "meu marido [ou irmão ou cunhado] é melhor para falar com você". À primeira vista, o conjunto de falas e comportamentos me pareceu timidez, baixa autoestima e/ ou resultantes de uma cultura/organização patriarcal - talvez não haja resposta, ou talvez a resposta não seja apenas uma. Aos poucos, procurei destituir a imagem de forasteira (que temia ser lida com autoridade) e, sentada no terreiro, bebendo café, ralando coco ou participando do fazimento da farinha, fui apresentada a personalidades fortes. Como me diria Dona Berta (77 anos) horas de conversa depois desse primeiro encontro, "ai dos homi se não fosse as muié".

Dona Brasília (85 anos), excepcionalmente, mostrou-se desde o início aberta ao diálogo e compartilhamento das 
suas memórias, um misto de jovialidade e sensibilidade política que me alerta: "a gente pensa que não acaba, mas acaba sim", disse ela depois de compreender o objetivo e atribuir importância ao meu trabalho de ausculta e produção de um livro com seu perfil. Aos poucos, Dona Brasília vai reproduzindo danças e cantos, desprendida da minha presença. Se inicialmente cheguei à Volta Miúda para aprender sobre história, cultura ou qualquer outro fato/ciência, a trajetória se desenvolveu, sobretudo, num exercício regressivo e aprendo sobre sentimento e percepção. Conhecer essas pessoas humaniza... "O importante é ser feliz, né?", sigo o caminho refletindo e Dona Zelita, mesmo sem saber, faz-me agradecer, silenciosamente.

Ao ver a mim como sintomática do mundo, num processo libertário - não introspectivo ou egoísta - me encontrei, calei a voz latente de um domínio simbólico que se protrai na destituição da independência, autonomia e autoconfiança dos sujeitos. Não se tratava de uma aventura ou desafio, mas da responsabilidade de contribuir, na prática, para a realização de uma dignidade que o meu discurso emanava. Fui aprendendo que a soma dos afetos que estabeleci com as pessoas que conheci, daqueles que eles conheceram e dos seus conhecidos, e dos descendentes que ainda virão, era o que dotava a alma deste livro de uma singularidade intocável. Fiz-me, então, um elo. 
豆 



\section{Da colonialidade à emancipação: uma história possível}

A história do território político soberano a que hoje se denomina República Federativa do Brasil inicia no contexto da política de expansão mercantilista europeia datada de meados do século XVI. O aprimoramento da tecnologia de navegação oceânica possibilitou o contato e relacionamento entre diferentes e distantes sociedades, e da mesma forma abriu caminhos para a sua conquista e subsunção a novas estruturas de poder. Alguns teóricos, a exemplo de Norberto Bobbio, Nicola Matteucci e Gianfranco Pasquino (1998) e Isabel de Castro Henriques (2014), segmentam o fenômeno da colonização ao destacar as características mais evidentes em determinados períodos. Importa trazer à baila que, se inicialmente a conquista de territórios para fins econômicos respondia à necessidade de as Nações se afirmarem diante das outras potências, por meio da conquista e garantia de fontes para exploração de riquezas materiais ou humana, por meio da escravidão -, o caráter político-ideológico da colonização se fortaleceu a ponto 
tal que a política internacional passou a ser remodelada pela capacidade de controle e ingerência política, econômica e cultural sobre outros povos.

Se, numa linguagem simplista, considerarmos que 0 desenvolvimento industrial adicionou à equação da acumulação de riqueza bruta e poder a necessidade de existência de mercado consumidor para as riquezas beneficiadas, a coIonização, sistematicamente implementada para fins de controle para exploração de riquezas, personifica-se no projeto político do colonialismo. O termo distancia a compreensão do colono como participante do processo de povoamento de novos territórios, aduzindo que a descontinuidade territorial e cultural apurada atende a fins mais amplos do que a mera exploração de riquezas. "O Colonialismo transforma-se num método de organização da produção baseado na exploração de uma força de trabalho privada de direitos políticos e sociais no âmbito do Estado colonial" (BOBBIO; MATTEUCCl; PASQUINO, 1998, p. 183), o que se destaca é o caráter deliberado da política colonialista para a dominação e repressão dos povos colonizados, protraindo os efeitos deste controle por meio da subalternização de grupos igualmente privados dos seus direitos, ainda que formalmente "descolonizados".

Quijano chama atenção ao fato de que com os movimentos de independência dos territórios conquistados e mesmo depois de eliminado o controle político direto dos colonizadores em relação às suas colônias - como no caso brasileiro, em 1822, quando fora declarada a independência em relação ao Reino Português -, "la relación entre la cultura europea, también 'occidental', y las otras sigue sendo una relación de dominación colonial" (QUIJANO, 1992, p. 12). A 
poética da sua escrita não afasta a nocividade do processo, que ultrapassa a dominação cultural, atuando diretamente no imaginário das sociedades, de forma a tornar-se, em certa medida, componente das individualidades. A descontinuidade identitária alcança a própria humanidade dos corpos, por reprimir sistematicamente as suas crenças, ideias, símbolos e conhecimentos.

Fazendo referência às práticas do colonialismo, mas num contexto pós-colonial, o imperialismo é enunciativo da hegemonia de um Estado em detrimento de outro, sobre o qual aquele exerce o controle econômico, subsumindo-o, inclusive, ideologicamente. Neste contexto é que se configura a transmutação das formas de dominação. Se outrora a dicotomia colonizadores e colonizados estabelecia o lugar social e jurídico do indivíduo, a proclamação de "independência" descaracterizou o status de colônia, implicando a remodelação das nomenclaturas de poder sem que houvessem mudanças estruturais. Neste âmbito, a subalternização de grupos atende de forma sistemática e estratégica aos interesses imperialistas e a divisão étnico-racial assume o papel de instrumento para depreciação da história e memória dos povos que deram origem à nação. Enquanto os brancos, outrora colonizadores, mantêm a sua soberania, a categoria dos colonizados é substituída pela dos negros - a cor da escravidão -, e mestiços, frutos da mistura inconcebível ${ }^{5}$ entre os grupos sucedidos.

É na deturpação da representação social conforme os interesses da cultura lato sensu hegemônica imposta que a lógica imperialista legitima a relação de dominação,
5. "Os mestiços eram de tal forma depreciados, e animalizados, que os naturalistas chegaram a temer que fossem estéreis, denominandoos 'mulatos', em associação às mulas". (SILVA, 2011, p. 162) 
[...] na medida em que as relações sociais que se estavam configurando eram relações de dominação, tais identidades foram associadas às hierarquias, lugares e papéis sociais correspondentes, como constitutivas delas, e, consequentemente, ao padrão de dominação que se impunha. Em outras palavras, raça e identidade racial foram estabelecidas como instrumentos de classificação social básica da população. (QUIJANO, 2005, p. 107).

O sociólogo peruano argumenta que a relação de dominação direta, política, social e cultural dos europeus introduziu uma estrutura colonial de discriminações. O raciocínio que se constrói é quanto à subsunção da lógica local para consolidação da identidade e estabilidade da nação brasileira, mas forjada sob os paradigmas que favorecem e são concebidos à perspectiva do colonizador. Se outrora os negros tinham sido descritos como decrépitos de espírito e disformes no corpo e, portanto, desinteressantes para a formação da sociedade brasileira - o que garantia a preponderância do europeu -, em dado percurso histórico se fez politicamente necessário que uma identidade própria fosse criada para consolidação da nação independente, e abriu-se concessão à miscigenação (SILVA, 2011). Destaca-se que, mesmo neste último cenário, permanece imaculada a hegemonia colonizadora, uma vez que, se na teoria fora criado um laço entre brancos e negros, a prática reservou-lhes a exclusão social. Complementando este raciocínio, Silvane Silva (2005) rememora Kabengele Munanga, o qual percebe que do fenômeno da miscigenação - enquanto fenômeno biológico - resulta um fato social, psicológico, econômico, político-ideológico, corroborando a ideia de que a política racial se estabeleceu no Brasil para atender aos interesses da elite branca/colonizadora. 
Considerando que "a representação do social se relaciona com a memória e a experiência, além da reflexividade, enquanto enunciado da modernidade, e tem implicação nas formas de reconhecimento nos planos social, cultural e político" (SCHERER-WARREN, 2010, p. 22), a subalternidade assimilada aos negros pode-se dizer fruto de um processo histórico de violência real, materializado na escravidão, e simbólica - aparentemente silente e indolor, mas altamente deletéria (BOURDIEU, 1989, p. 10) -, que culminou no alijamento da sua cidadania.

Decerto, esse processo de depreciação social, identitária e histórica voltada à marginalização da população negra se sustentou graças à manutenção institucionalizada da política colonialista, que fundamenta o Estado brasileiro. Abdias Nascimento alerta:

Seja dito desde o início os afro-brasileiros formam uma etnia encurralada pelo cerco de um sistema de pressões que vão desde o preconceito e a discriminação veladas, até as agressões culturais e/ou psicológicas, assim como se radicalizam em violências abertas de sentido econômico e de cunho policial ou institucional. [...] - está condenado ao desaparecimento ditado pela sociedade dominante, pois assim está determinado pela lógica da política racial vigente no país. (NASCIMENTO, 2019, p. 186).

A hegemonia das potências imperialistas prescinde da fragmentação nacional e hierarquização das relações de poder, fomentadas pela subalternização de determinadas categorias sociais e o seu afastamento aos direitos e garantias de desenvolvimento, pois, ao passo em que o negro é desconsiderado em sua humanidade, o mecanismo ideológico 
escuda esse próprio grupo hegemônico da responsabilidade social para com o futuro desses ex-escravizados e seus descendentes.

Neste contexto se elucida o porquê da representação social pejorativa atribuída à população negra, de forma animalizada, construída de forma apartada da dimensão humana da existência intelectual, sensitiva, cultural e emocional, haja vista que, um dos paradoxos da situação colonial (BALANDIER, 2014, p. 46-47) instaurada é a preponderância da influência sociológica, ainda que por um grupo numericamente inferior. $O$ que realmente importa/define $\mathrm{n} /$ esta relação e seus desdobramentos é a manutenção do lugar do dominador e do dominado.

É consentâneo pensar que, tendo sido as relações étnico-raciais estabelecidas no Brasil sob o critério da colonialidade, o processo de exclusão social e usurpação da cidadania tem na educação - sem o prejuízo de outros espaços - terreno fértil à contínua subalternização da população negra e seus descendentes. E isto se afirma por dois vieses: em primeiro plano, destaca-se a apatia constitucional voltada à inserção da população negra na escola, e em segundo plano a desvalorização dos saberes, métodos e instrumentos formativos deslocados do modelo eurocêntrico, mas inerentes à cultura negra e de riqueza historicamente ignorada.

Boaventura de Sousa Santos (2009) denomina conhecimento o que aqui se refere, de forma institucionalizada, como educação. Trata-se de linguagem política responsável por traduzir a práxis social, de forma inteligível, trazendo-a ao plano da existência. Esta compreensão denota que a concepção moderna do conhecimento é dotada de 
intencionalidade nociva à coexistência de saberes, partindo-se do pressuposto de que a imposição de uma forma de saber é uma manifestação de controle político. Desta maneira, a colonização dos saberes não implica apenas a subalternização de outros saberes ou o impedimento de que grupos não hegemônicos os apreendam, mas implica também a alienação do fazer histórico e cultural de uma dada comunidade, levando-a a ignorar os percursos formativos que ultrapassem a normalidade concebida, ainda que lhes sejam natos.

Neste ponto, educação e direito se intersectam. Se por um lado, a ciência moderna monopoliza o certo e o errado, o verdadeiro e o falso, o direito moderno estatui o legal e o ilegal, fazendo erigir a legitimidade unidirecional do Estado tal como se postulasse o direito das gentes. Por intermédio de tais instrumentos se consolidou a hegemonia eurocentrada, ignorando-se as vidas e vivências concebidas além dos seus conceitos. Santos (2009, p. 26) elucida que, "em cada um dos dois grandes domínios - a ciência e o direito - as divisões levadas a cabo pelas linhas globais são abissais no sentido em que eliminam definitivamente quaisquer realidades que se encontrem do outro lado da linha", universo de experiências desperdiçadas e invisibilizadas, tal qual os seus autores.

A racialização das relações sociais e o alijamento da população negra do processo educacional formativo - ainda que em termos eurocentrados - instauram a orfandade cultural, uma vez que suas práticas e saberes não são sequer reconhecidos, e mutilam as possibilidades de participação desta parcela da população no processo/modelo político instaurado. Se, por um lado, a ampliação do acesso 
à educação é crucial à elementar dignidade, a representatividade dos conteúdos e práticas pedagógicas é igualmente sensível e necessária à democratização de saberes. Nesse sentido é que se perquire o reconhecimento do negro enquanto cidadão, a partir do desenvolvimento de um direito à educação hábil a percebê-lo em sua humanidade, ratificando que, como assevera Santos (2009, p. 32), a injustiça social está intimamente ligada à injustiça cognitiva global.

Considerando-se, pois, que a evolução da política educacional dialogue com o seu afastamento da lógica coIonialista, o reconhecimento das relações étnico-raciais se instala como necessário à realização daquele princípio, assim como vai de encontro às hierarquizações sociais concebidas para a manutenção das relações de poder advindas da colonização. Nesse ínterim é que se torna pertinente o questionamento sobre desde quando as portas das escolas brasileiras estão de fato abertas à população pluriétnica e pluricultural que conforma esta sociedade.

Tendo a dignidade da pessoa humana por fundamento (BRASIL, 1988, Art. $1^{\circ}$ ), enquanto Estado Democrático de Direito, a República pós-ditadura nasce com o objetivo de erradicar a pobreza, reduzir as desigualdades sociais e regionais e promover o bem de todos sem prejuízo de origem, raça, sexo, cor, idade e quaisquer outras formas de discriminação (BRASIL, 1988, Art. $3^{\circ}$ ). Conquanto termos similares já tivessem sido cunhados noutros textos constitucionais, a diferenciação está na busca da realização desses objetivos em função de um patamar de dignidade humana, com vistas ao alcance de uma igualdade substantiva, material. Em consonância, se outrora houvera disposições esparsas, 
a Constituição analítica estatui explicitamente a educação como direito social. Sobre a imperatividade dos direitos sociais, econômicos e culturais, Flávia Piovesan (2014, p. 173) concorda que a "ideia da não acionabilidade dos direitos sociais é meramente ideológica e não científica", sendo, irrefutavelmente, exigíveis, o que também reforça a pauta dos movimentos sociais.

Abramovich e Courtis (1997, p. 337) reiteram, sobre a previsão dos direitos sociais, que “Lo que calificará la existência de um derecho social como derecho pleno no es simplemente la conducta cumplida por el Estado, sino la existencia de algún poder jurídico para actuar del titular del derecho em caso de incumplimiento de la obligación debida". Neste ponto de vista, a abertura de possibilidade para a transformação da práxis representa um avanço em contraponto à participação popular na realização da sua liberdade, até então formalmente inaudível pela figura Estatal.

O artigo 205 da Constituição de 1988 localiza a educação como direito de todos e dever do Estado e da família, a ser promovida e incentivada com a colaboração da sociedade, com os objetivos de desenvolver a pessoa, prepará-la para o exercício da cidadania e qualificá-la para o trabalho. Do emblemático artigo $5^{\circ}$ advém o imperativo que se desdobra na inderrogável tarefa de repensar a política educacional brasileira: “XLI - a lei punirá qualquer discriminação atentatória dos direitos e liberdades fundamentais; XLII - a prática do racismo constitui crime inafiançável e imprescritível, sujeito à pena de reclusão, nos termos da lei" (BRASIL, 1988, Art. $5^{\circ}$ ). Ora, se o repúdio ao terrorismo e ao racismo é princípio da República, a descolonização das práticas 
educacionais é conduta imprescindível a fim de que o passivo histórico-social não torne o Estado em verdugo à própria instituição.

Estas perspectivas favorecem a interpretação culturalista e identitária dos movimentos sociais, que, em termos de estudos pós-coloniais, argumentam ser possível a liberdade, com a desconstrução das formações discursivas e da construção de novas subjetividades dos sujeitos historicamente oprimidos e discriminados. A superação das formações discursivas é possível na deflagração da "outra face" oculta e essencial da modernidade implantada, produto do desenvolvimento e notabilidade eurocêntrica: o mundo periférico colonial (SCHERER-WARREN, 2010, p. 20-21).

Compreendendo-se, então, que a hierarquização das relações sociais adveio da imposição de uma cultura colonialista; que a manifestação sociocultural dos povos que, de fato, promoveram o povoamento e ergueram o território Brasil foi violentamente reprimida; que, por consequência, o modelo educacional estabelecido foi silente quanto à inserção desta população, por séculos alijada da alfabetização e dos mecanismos necessários à construção da sua cidadania de forma a perpetuar as condições de dominação e privilégio da elite econômica, quaisquer princípios que decorram deste sistema afrontam o estatuído princípio da dignidade humana.

Ao discorrer sobre princípios para a investigação e análise de práticas dialógicas entre estudos pós-coloniais e movimentos sociais latino-americanos, Scherer-Warren (2010, p. 21-26) faz conclusões que facilitam a compreensão da correlação aqui estabelecida quanto à análise do 
desenvolvimento da política educacional do ponto de vista pós-colonial, com vistas à sua consecução no âmbito das relações étnico-raciais. Se, como já referenciado, o processo de representação social se relaciona com a memória e experiência, o reconhecimento social, cultural, político e epistêmico desta população subalternizada deve ser promovido com a ocupação desses lugares por atores negros e pela pluralidade étnico-cultural formadora do Brasil, em contraponto à marginalização da cultura, saberes e práticas formativas ou educacionais em relação aos centros hegemônicos de poder.

Em relatório intitulado "Faces da Desigualdade no Brasil: um olhar sobre os que ficam para trás", coordenado pela economista Tereza Campello (2017), o acesso aos espaços de formação e formulação de conhecimento por atores negros - que correspondem a mais da metade da população brasileira - é quantificado, a partir de dados do Instituto Brasileiro de Geografia e Estatística (IBGE). Nos dados analisados entre os anos de 2002 e 2015, verificou-se o aumento de $117 \%$ na taxa de jovens negros de 15 a 17 anos, cursando o Ensino Médio, enquanto a presença de jovens negros na universidade cresceu $268 \%$ no mesmo período. A publicação argumenta que tal êxito se deu em função da "ampliação do acesso na busca da universalização que permitiu a inclusão massiva nas políticas sociais, aliada ao aumento da renda do trabalho" (CAMPELLO, 2017, p. 47), com inovações legislativas significativas concernentes à temática das relações étnico-raciais.

O período assinalado foi de grande efervescência legislativa no tocante às relações étnico-raciais e teve como marco a Declaração e Programa de Ação de Durban adotados 
na III Conferência Mundial de Combate ao Racismo, Discriminação Racial, Xenofobia e Intolerância Correlata, realizada em Durban, África do Sul, em 2001. No ano seguinte, o Programa Nacional de Ações Afirmativas foi criado por meio do Decreto n. ${ }^{\circ}$ 4.228, de 13 de maio de 2002 (BRASIL, 2002), pautando reivindicações há muito ecoadas pelos movimentos sociais. Posteriormente, a Lei de Diretrizes e Bases da Educação - Lei n. ${ }^{\circ} 9.394 / 96$ (BRASIL, 1996) - passou por alterações significativas, promovidas pela Lei n. ${ }^{\circ}$ 10.639/03 (BRASIL, 2003) que, acrescendo-lhe os artigos 26-A, 79-A (posteriormente vetado), e 79-B, incluiu a temática "História e Cultura Afro-Brasileira" no currículo oficial da educação básica, e incluiu no calendário escolar a data 20 de novembro como "Dia Nacional da Consciência Negra". Estes diplomas viriam a ser novamente alterados, por meio da Lei n. ${ }^{\circ} 11.645 / 08$ (BRASIL, 2008), para incluir também como temática obrigatória a ser trabalhada em toda a educação básica, nas redes pública e privada de ensino, a história e a cultura dos povos indígenas do Brasil.

Ao regulamentar as alterações promovidas, o ConseIho Nacional de Educação, por meio da Resolução $n .^{\circ}{ }^{1}$, de 17 de junho de 2004, institui as Diretrizes Curriculares Nacionais para a Educação das Relações Étnico-Raciais, tendo por meta promover a educação de cidadãos atuantes e conscientes no seio da sociedade multicultural e pluriétnica (BRASIL, 2013) - e o faz em tom coercitivo às unidades de ensino, haja vista que a sua implementação passaria a ser considerada para avaliação das condições de funcionamento dos estabelecimentos. Ratificando os progressos alcançados no âmbito da política educacional, o Brasil ainda aprova nos anos de 2009 e 2010, respectivamente, o Plano Nacional de 
Promoção da Igualdade Racial (Decreto n. ${ }^{\circ} 6.872$ / 09 - BRA$\mathrm{SIL}, 2009$ ) e o Estatuto da Igualdade Racial (Lei n. ${ }^{\circ} 12.288$, de 20 de julho de 2010 - BRASIL, 2010).

No tocante às taxas de analfabetismo das pessoas de 15 anos ou mais de idade, a Pesquisa Nacional por Amostra de Domicílios (PNAD) promovida pelo IBGE constatou, no ano de 2002, que 7,5 \% da população brasileira declarada como branca não era alfabetizada, em contrapartida, esta porcentagem era significativamente superior em relação aos pretos (16,7\%) e pardos (17,3\%) (BRASIL, 2003). No ano de 2015, percebe-se a redução geral da taxa de analfabetismo, mas, ainda assim, o grupo de pretos ou pardos se encontra em desvantagem gritante, visto que a taxa de analfabetismo para esse grupo $(10,6 \%)$ é mais que duas vezes superior à taxa da população branca (4,9\%) não alfabetizada. Nesse mesmo ano, pretos ou pardos correspondiam a 53,9\% da população brasileira (BRASIL, 2016). Já no ano de 2019, a Síntese de Indicadores Sociais do PNAD aponta a permanência da desigualdade: a taxa de analfabetismo entre as pessoas brancas é de 3,9\% e entre os pretos e pardos é de $9,1 \%$ (IBGE, 2O2Ob). Ainda conforme o último levantamento, no tocante à situação de domicílio, $5,1 \%$ da população urbana e $17,5 \%$ da população rural são analfabetas.

Depreende-se, por meio dos dados analisados, que as políticas públicas implementadas impactaram de maneira positiva, porém incipiente, no tocante à inserção da população negra no sistema formal de ensino e na sua alfabetização - ainda, os dados demonstram que há uma superposição de opressões em relação às comunidades quilombolas que, além da negritude, carregam o caractere ruralista, em 
relação ao qual a discrepância do acesso à educação é ainda mais alarmante. Importa destacar que a descolonização do ambiente educacional implica a ocupação dos espaços por atores negros, assim como a reformulação epistêmica, a partir das suas experiências e vivências, capaz de reconhecer valores culturais historicamente negados, pois, como asseverado por Petronilha Beatriz Gonçalves e Silva no parecer relativo às Diretrizes Curriculares Nacionais para a Educação das Relações Étnico-Raciais e para o Ensino de História e Cultura Afro-Brasileira e Africana:

Reconhecimento implica justiça e iguais direitos sociais, civis, culturais e econômicos, bem como valorização da diversidade daquilo que distingue os negros dos outros grupos que compõem a população brasileira. E isto requer mudança nos discursos, raciocínios, lógicas, gestos, posturas, modo de tratar as pessoas negras. Requer também que se conheça a sua história e cultura apresentadas, explicadas, buscando-se especificamente desconstruir o mito da democracia racial na sociedade brasileira; mito este que difunde a crença de que, se os negros não atingem os mesmos patamares que os não negros, é por falta de competência ou de interesse, desconsiderando as desigualdades seculares que a estrutura social hierárquica cria com prejuízos para os negros. Reconhecimento requer a adoção de políticas educacionais e de estratégias pedagógicas de valorização da diversidade, a fim de superar a desigualdade étnico-racial presente na educação escolar brasileira, nos diferentes níveis de ensino. (BRASIL, 2013, p. 134, grifos meus).

Se por um lado, a interpretação dos direitos humanos prolatados em sede constitucional possa influenciar a universalização do ensino, a descolonização epistêmica implica 
assimilá-la numa concepção da igualdade material. Ou seja, compreendendo os sujeitos subalternizados como cidadãos de direito e, mediante as suas experiências e saberes, aplicar-se-ia os direitos humanos a partir de um universalismo capaz de considerar as diferenças. Esta reinterpretação realoca o próprio sentido do direito à educação, que, outrora concebido num status de concessão, passa a ser incorporado como prerrogativa inerente ao sujeito, percebido em sua inteireza social, cultural e histórica. O qual é, ao mesmo tempo, hábil a prolatá-lo, ainda que em termos diversos ao modelo imposto.

De grande relevância é a percepção crítica das relações étnico-raciais que Ramón Grosfoguel faz no prisma da depreciação da população e cultura negras pela imposição de uma lógica imperialista com raízes no colonialismo.

\footnotetext{
O facto de alguém se situar socialmente no lado oprimido das relações de poder não significa automaticamente que pense epistemicamente a partir de um lugar epistémico subalterno. Justamente, o êxito do sistema-mundo colonial/moderno reside em levar os sujeitos socialmente situados no lado oprimido da diferença colonial a pensar epistemicamente como aqueles que se encontram em posições dominantes. As perspectivas epistémicas subalternas são uma forma de conhecimento que, vindo de baixo, origina uma perspectiva crítica do conhecimento hegemónico nas relações de poder envolvidas. (GROSFOGUEL, 2008, p. 46, grifos meus).
}

A retomada das perspectivas ignoradas é tarefa primária para o questionamento de uma sociedade que se estabeleceu pelos valores do homem masculino, heterossexual, 
branco, patriarcal, cristão, militar, capitalista e para o amadurecimento de infindos questionamentos sobre os sujeitos, lugares, verdades e valores consolidados. Abre-se um novo e longo caminho de percepções e reformulações teóricas e práticas, que revelam a tríade basilar da representação social - posição, localização e memória - contingencialmente. A pós-colonialidade imprime um novo paradigma à coexistência de memórias, implicando a reflexão sobre onde e por que tais e tais sujeitos ocupam e habitam seus respectivos lugares sociais.

Quijano (2009, p. 74) adverte que o "eurocentrismo não é exclusivamente, portanto, a perspectiva cognitiva dos europeus, ou apenas dos dominantes do capitalismo mundial, mas também do conjunto dos educados sob a sua hegemonia". Conceber uma mudança epistêmica e, portanto, política, com vistas a uma emancipação cognitiva dos sujeitos de direito, implica perceber os negros e sua pluralidade cultural - enquanto representativos das populações subalternizadas -, como fontes de conhecimento e detentores dos espaços de aprendizagem e produção de saberes. Portanto, pensar um direito à educação no Brasil implica questionar o acesso das populações negras à escola, assim como à sua liberdade de manifestação epistêmico-cultural para além dos modelos impostos.

A colonialidade de fato alterou a conformação da sociedade brasileira, afetou a priorização política e permitiu o continuísmo de condutas arbitrárias e contrárias aos ideais da liberdade e dignidade humanas. O caminho para a transformação desta realidade implica a abertura de caminhos às culturas ignoradas, dar voz para a produção do 
conhecimento que se afaste dos modelos e paradigmas eurocêntricos. Esta crítica é feita pelo professor e historiador Francisco Antônio Nunes Neto, ao tratar sobre o avanço obtido após o advento da Constituição de 1988 no tocante à normativa que estabeleceu, no ano de 2003, por meio da Lei n. ${ }^{\circ} 10.639$, as Diretrizes Curriculares Nacionais para a Educação das Relações Étnico-Raciais e para o Ensino de História e Cultura Afro-Brasileira e Africana. O estudioso afirma que tal mudança se deu em função da

\footnotetext{
[...] constatação entre pesquisadores e estudiosos de diversas áreas do conhecimento e como uma decorrência da ação política, denunciatória e reivindicativa dos movimentos sociais de que o teor da escrita da história pátria não foi elaborada na perspectiva dos colonizados, de suas contribuições no processo de formação cultural do País, nem a partir dos seus relatos, muito menos dos seus processos civilizatórios [...]. (NUNES NETO, 2016, p. 133).
}

Uma educação para além das amarras da colonialidade prescinde de um processo intrínseco, da promoção do autoconhecimento e retorno às origens histórico-culturais que, paradoxalmente, incutiram nos negros o lugar da subalternidade. Ser livre, nesta concepção, é ter preservadoe efetivado o direito à memória. Para romper com as amarras da subsunção cognitiva e, portanto, formativa do cidadão, fundamental é a constituição de práticas pedagógicas que promovam o acesso à história e cultura afrodescendente, a fim de que os sujeitos sejam capazes de perceber o seu lugar no mundo - essência da transformação social. 
A formação da identidade brasileira se deu com a integração de pluralidades culturais, tornando-a, nas palavras de Kabengele Munanga, uma "colcha de retalhos". $O$ autor considera que essa diversidade característica faz com que a chamada cultura nacional "não impeça a produção cultural das minorias étnicas, apesar da repressão que existiu no passado, mas apenas consiga inibir a expressão política dessas enquanto oposição dentro do contexto nacional" (MUNANGA, 2009, p. 452). Considerando, pois, que "a identidade é um processo sempre negociado e renegociado, de acordo com os critérios ideológico-políticos e as relações de poder" (MUNANGA, 2009, p. 453), preservar a memória afrodescendente é ir de encontro às estratégias de homogeneização histórico-cultural que aprofundam as disparidades sociais. 
豆 



\section{4}

\section{Os caminhos trilhados}

para a concretização do direito à memória quilombola

A posição no rol dos direitos humanos evidencia que o exercício da vivificação ou preservação da memória é requisito para a concretização da humanidade do ser ou, em outros termos, da dignidade da pessoa humana - princípio estrutural do ordenamento jurídico brasileiro. O predicado "fundamental" é incorporado ao direito à memória por ser expressamente tutelado pela Constituição Federal. O conceito desse direito está sendo referido em sua acepção histórica, pois, dizer da existência de um direito à memória é abrir caminhos a que cada brasileira e brasileiro perquira sua verdadeira identidade, muito além do discurso hegemônico.

Por ser o direito à memória de caráter humano/fundamental, a correlação entre memória e identidade é inevitável, assim como a rediscussão da liberdade nos tempos em que os grilhões já não são mais visíveis e as relações 
hierarquizadas impõem uma cultura homogeneizante. Ao situar a discussão neste contexto, a memória se apresenta de forma politizada e cujas implicações ultrapassam o viés teórico-filosófico, alcançando o processo de autoafirmação dos sujeitos e o necessário repensar da liberdade.

Isto posto, ratifica-se que o resgate da origem histórico-cultural do povo brasileiro é instrumento para a consecução da sua dignidade e essencial, portanto, ao seu reconhecimento enquanto sujeito-cidadão. Por consequência, promover a ausculta e transliteração das memórias de uma comunidade remanescente quilombola localizada no extremo sul do estado da Bahia reveste-se de importância social enquanto produção de conhecimento pela, para e acerca da localidade, com vistas à documentação de fatos históricos e culturais presentes na memória dos anciãos, assim como por instrumentalizar o ensino de história na rede regular de ensino em uma perspectiva decolonial.

Ao discutir a memória como conceito jurídico, político e sociológico, o termo se preenche, assume feição imperativa sob a pena de ser o caráter humano olvidado em sua inteireza. Tal qual o direito à memória, o direito à educação também se situa no âmbito dos direitos humanos, visto, portanto, como pressuposto para a dignidade humana. Se do ponto de vista histórico-sociológico, a memória é elemento fundante da identidade e a Educação é direito social elementar, dever do Estado, a interseção desses conceitos implica refletir a formação do sujeito. E é consequente, também, a indagação sobre a sua manifesta (e precária) liberdade, tutelada pelo Estado de direito que é, ao mesmo tempo, precursor do processo educacional formativo do 
cidadão recorrentemente executado como mecanismo de alfabetização desmemoriada.

Considerando-se uma comunidade quilombola, investigar a efetivação do direito fundamental à memória gravita nos termos da sua emancipação e resistência aos ditames sociopolíticos elitizados e limitadores, advindos de uma sociedade que é concebida à margem da sua história - nisto inclui-se a marginalização da população negra - e de um Estado que atua tardiamente na equalização desse passivo. A Educação e a Memória são direitos constitucionais - e linhas globais abissais -, sua interação imprime o necessário repensar histórico e cultural apreendido e imposto pelo discurso hegemônico. Neste ponto, fundamental é a promoção de instrumentos e práticas educacionais, a fim de contribuir com a cisão da colonialidade.

A busca pela efetivação do direito à memória quilombola, numa perspectiva atinente às epistemologias do sul, demandou múltiplas ferramentas, no âmbito da pesquisa qualitativa e investigação social. Da pesquisa bibliográfica e historiográfica, estudos exploratórios, à metodologia central de produção da pesquisa a partir da história oral. A pesquisa bibliográfica ou revisão de literatura foi um recurso fundamental para a compreensão prévia do(s) campo(s) em que o tema se insere, especialmente para a realização das entrevistas - "o primeiro ponto é a preparação de informações básicas, por meio da leitura e de outras maneiras" (THOMPSON, 1992, p. 254). As informações contextuais servem à localização científica da abordagem e conhecimento, pelo pesquisador, acerca de teorias, controvérsias e lacunas a serem exploradas (FLICK, 2009, p. 62), daí a importância (e 
6. Em Memórias da Plantação - episódios de racismo quotidiano, livro oriundo da trajetória de mestrado de Grada Kilomba, a autora descreve suas escolhas metodológicas na seção "Decidindo pela pesquisa centrada em sujeitos", elucidando o seu trabalho como "um espaço para performar a subjetividade, para reconhecer mulheres negras, em particular, e pessoas negras em geral, como sujeitos desta sociedade - em

todos os sentidos reais da palavra" (KILOMBA, 2019, p. 81). À sua semelhança, compreendemos que o processo de decisão metodológica é conteúdo teórico elementar à

compreensão deste livro como instrumento decolonial. necessidade) de tomá-la à primeira mão para o desenvolvimento das etapas posteriores.

O estudo em campo foi realizado de maneira contínua, uma vez que o processo interativo entre pesquisadora e público alvo é necessário à consecução dos objetivos da pesquisa (FLICK, 2009, p. 110). Tal estudo foi fundamental à consecução do método da história oral ${ }^{6}$ que norteou a coleta de dados, propiciando desde a abordagem inicial dos sujeitos da pesquisa à viabilização das entrevistas, realizadas individualmente (MARTINS; THEÓPHILO, 2007, p. 72). Estas foram precedidas do processo de sensibilização dos participantes e coleta preliminar de dados, prévia à preparação do roteiro "mapeando o campo e colhendo ideias e informações", como ensinou Thompson (1992, p. 254).

A escuta orientada visou à compreensão da comunidade e do seu percurso histórico, visto que para Paul Thompson (1992, p. 197), “toda fonte histórica derivada da percepção humana é subjetiva, mas apenas a fonte oral permite-nos desafiar essa subjetividade: descolar as camadas de memória, cavar fundo em suas sombras, na expectativa de atingir a verdade oculta". Assim, as falas captadas e as leituras sobre/ durante o processo de entrevista gozaram de espaço e importância na constituição do trabalho e as observações foram registradas em caderno de campo (ALBERTI, 2005, p. 100), tais como: descrição das entrevistas, dificuldades e interrupções, informações obtidas e que não foram gravadas, reação dos entrevistados, como se deu a finalização da entrevista, entre outros.

Para a realização das entrevistas, utilizou-se a técnica semipadronizada, a fim de permitir o desenvolvimento 
da abordagem subjetiva e sua reflexão (FLICK, 2009, p. 148154), do tipo temática, versando prioritariamente sobre a participação do entrevistado no tema escolhido, conforme Alberti (2007, p. 175). Considerando que um questionário detalhado e preciso limitaria o desenvolvimento do discurso da testemunha, e que se "for deixada totalmente livre, há o risco de se afastar do tema tratado", Chantal de Tourtier-Bonazzi (2006, p. 237) também considera a entrevista semiestruturada mais adequada à captação da história oral, como se pleiteava.

$O$ roteiro geral de entrevistas foi elaborado com base na pesquisa exaustiva sobre o tema, com a "síntese das questões levantadas durante a pesquisa em fontes primárias e secundárias", com vistas a orientar as atividades posteriores, sobretudo a preparação dos roteiros individuais (ALBERTI, 2005, p. 83). Respeitadas as peculiaridades da trajetória e experiências de cada entrevistado, os roteiros foram elaborados sob uma base comum, permitindo que se identificasse "divergências, recorrências ou ainda concordâncias entre as diferentes versões obtidas ao logo da pesquisa, aprofundando-se as possibilidades de análise do acervo" (ALBERTI, 2005, p. 84). Então, a elaboração dos roteiros individuais se deu após a aplicação do roteiro geral, a partir do qual foram listados temas sensíveis aos sujeitos entrevistados, que fui identificando desde os primeiros diálogos.

Verena Alberti (2005, p. 18) se refere à história oral como "método-fonte-técnica" que "privilegia a realização de entrevistas com pessoas que participaram de, ou testemunharam, acontecimentos, conjunturas, visões de mundo", aspecto de relevância maior que se espera alcançar neste trabalho. Segundo ela, "trata-se de estudar acontecimentos históricos, 
instituições, grupos sociais, categorias profissionais, movimentos, conjunturas etc. à luz de depoimentos de pessoas que deles participaram ou os testemunharam" (ALBERTI, 2005, p. 18), e, por isso, a pesquisa foi desenvolvida por meio de entrevistas gravadas com anciãs/os quilombolas que guardam memórias sobre os jeitos de ser e viver dos antepassados próximos. No que tange ao fator etário, Alberti (1992, p. 85) considera preferível começar a entrevistar os mais idosos, em razão da relevância de se alcançar fatos pretéritos, cujos aspectos e sentidos estejam ocultos ou tenham sido invisibilizados, especialmente para a realização desta pesquisa.

Ao prefaciar o livro Memória e Sociedade: lembranças de velhos, escrito por Ecléa Bosi, Marilena Chauí adverte que

\begin{abstract}
a memória não é oprimida apenas porque lhe foram roubados suportes materiais, nem só porque o velho foi reduzido à monotonia da repetição, mas também porque uma outra ação, mais daninha e sinistra, sufoca a lembrança: a história oficial celebrativa cujo triunfalismo é a vitória do vencedor a pisotear a tradição dos vencidos. (CHAUí, 1994, p. 19).
\end{abstract}

E, por considerar a memória como a ponte entre presente e passado, Bosi defende a sua interferência no processo "atual" das representações, sendo responsável por deslocar percepções e ocupar o espaço da consciência, a "memória aparece como força subjetiva ao mesmo tempo profunda e ativa, latente e penetrante, oculta e invasora" (BOSI, 1994, p. 46-47) e, exatamente por isso, é elemento imprescindível à proposta de descolonização de saberes. 
A receptividade e simplicidade dos moradores de Volta Miúda tornavam incômoda a percepção do egoísmo e espírito defensivo comuns à vida urbana resultantes dos princípios da modernidade-racionalidade. Na miudeza ignorada, mundos de sentimentos afloravam em olhares, tons e ritmos sonoros, na apreensão da vida que não possui fim em si mesma, mas que se realiza em comunidade. Na Volta Miúda memorada não se percebia espaço para o individualismo, as narrativas evocavam um sentido coletivo das experiências e, mesmo quando nos verbos de ação o "eu" predominava, o sujeito não existia no mundo para si ou dissociado da sua responsabilidade para com os fazeres da comunidade - sejam eles religiosos, culturais ou quotidianos.

As/os participantes da pesquisa foram selecionados segundo os critérios: geográfico e de pertencimento, visto que se buscou moradores da Comunidade Quilombola de Volta Miúda, Caravelas/BA; etário, posto que, tendo em vista o caráter memorial da pesquisa, à guisa de alcançar informações sobre a história e cultura da comunidade, buscou-se identificar os indivíduos com idade superior a 60 anos em virtude da vivência e repertório referentes a práticas e experiências anteriores aos mais novos, cujos aspectos e sentidos estejam ocultos ou tenham sido invisibilizados; gênero, pois também objetivou-se alcançar equilíbrio entre homens e mulheres entrevistados e perfilados. O consentimento tratou-se de critério procedimental, também considerado como critério de inclusão, haja vista que a participação dos sujeitos na pesquisa implicaria a utilização/publicação das informações e imagens concedidas/ obtidas. A concordância foi dada por todas/os e, ao todo, cinco 
7. Conforme os parâmetros éticos adotados pela área das Ciências Humanas, Sociais e Sociais Aplicadas e pelo Comitê de Ética da Universidade Federal do Sul da Bahia (UFSB) mulheres e cinco homens foram perfiladas/os. As entrevistas aconteceram em locais escolhidos pelas/os próprios participantes, sendo a maioria em suas próprias casas, o que garantiu um ambiente confortável e familiar, deixando as/os entrevistadas/os mais à vontade na condução do processo.

No que tange às questões formais-legais, as entrevistadas e entrevistados assentiram formalmente em participar da pesquisa, mediante assinatura de Termo de Consentimento Livre e Esclarecido para as fontes que, além de ser produzido numa linguagem acessível ${ }^{7}$, foi por mim lido e explicado. Na qualidade de pesquisadora, fui à comunidade e abordei os sujeitos, individualmente, em suas residências e a fim de apresentar-me, como mestranda do Programa de Pós-Graduação em Ensino e Relações Étnico-Raciais da Universidade Federal do Sul da Bahia, e explicar a motivação da visita e da pesquisa, tema e objetivos, convidando-os à integração na qualidade de sujeitos participantes, entrevistada/os a serem perfilada/os.

Após a apresentação do roteiro geral das entrevistas, expliquei sobre a necessidade de consentimento expresso para a participação e cessão do direito de uso sobre o conteúdo e imagens a serem fornecidos no seu decorrer e, diante da plena compreensão por parte do/a pretenso/a entrevistado/a sobre os aspectos elementares da pesquisa e a implicação do seu consentimento e fornecê-lo de forma livre e esclarecida, as entrevistas foram acontecendo conforme a disponibilidade de cada um dos/as entrevistados/as. Todos os encontros aconteceram na própria comunidade, a grande maioria na residência dos próprios entrevistados. Os registros das entrevistas foram feitos em áudio e fotografias, a 
gravação em vídeo foi inviabilizada pela ausência de equipamentos adequados à obtenção de uma qualidade razoável.

Interessante notar as peculiaridades dos relatos, quanto às diferenças de perspectivas para análise e relembrar dos fatos, enquanto para os homens foi marcante o eixo centrado nas ocupações laborais, as mulheres expressavam apreço preponderante às relações familiares. Os procedimentos foram escolhidos a fim de possibilitar a captura destas nuanças, tal como o diálogo inicial com as mulheres, que ao ser, geralmente, precedido de falas como "eu não sei falar", "eu não sou boa nisso", "meu marido [ou irmão ou cunhado] é melhor para falar com você", faz denotar uma autoestima minorada ante a cultura/organização sexista ${ }^{8}$.

Nos dizeres de Ana Lugão Rios e Hebe Mattos (2005, p. 29), as memórias forjadas no âmbito do cativeiro, ou a partir dele, têm o condão de recuperar a historicidade dos diferentes processos de desestruturação da ordem escravista e de "desnaturalizar a noção de raça, percebendo as categorias e identidades raciais como construções sociais historicamente determinadas". Carlos Vogt e Peter Fry (1996, p. 25) criticam a tergiversação sobre o fenômeno da "resistência cultural", alegando que a resistência dos traços culturais afrodescendentes "não é um processo simples que se dá no confronto entre duas culturas imutáveis no tempo", pois, ao conceber a resistência como "sintoma de certa pujança metafísica das culturas africanas", pretere-se a consciência quanto aos enfrentamentos entre grupos, categorias e indivíduos, "para quem a cultura orienta a ação política e é ao mesmo tempo uma arma usada para empreendê-la".
8. Isto se afirma sem olvidar a força e presença dessas mulheres dentro da própria comunidade - paradoxo que faz remeter a que a interpretação e instrumentalização das noções e palavras podem servir à ratificação ou retificação das fraturas e discrepâncias sociais. Quando os lugares sociais são lidos ao ponto da sua teorização e com a objetificação dos sujeitos, admite-se tais afastando-se a sua humanidade, projetase a subalternização. Quando o observador se coloca atrás do sujeito a fim de perceber a sociedade, permite-se a interpretação da sua racionalidadesensibilidade e, portanto, resistência ante a prática e discurso desumanizador. 
A compilação da oralidade em perfis biográficos foi estratégia pensada na perspectiva da luta antirracista, a fim de romper os muros da escola e do ensino formal, mas também nesse contra movimento científico. Reverenciando-se a Comunidade de Volta Miúda para leitura de uma personalidade coletiva lida a partir de trajetórias individuais, concretiza-se o direito a essas memórias negadas pelas oficialidades, hábil a desnaturalizar concepções histórico-culturais-identitárias de quilombolas, caravelenses, teixeirenses.

Os perfis biográficos, textos do gênero do jornalismo literário, pareceram-me hábeis à captação das nuanças histórico-culturais expressas nas trajetórias individuais das/os entrevistadas/os. Sua formatação sucinta e fluida, em geral, profunda, permitiu que a voz das/dos mesmas/os fosse preservada tanto quanto possível, com os alinhavos necessários à técnica da palavra da escrita. O jornalista e professor Sérgio Vilas Boas ensina que os perfis biográficos

\begin{abstract}
cumprem um papel importante que é exatamente gerar empatias. Empatia é a preocupação com a experiência do outro, a tendência a tentar sentir o que sentiria se estivesse nas mesmas situações e circunstâncias experimentadas pelo personagem. Significa compartilhar as alegrias e tristezas de seu semelhante, imaginar situações do ponto de vista do interlocutor. Acredito que a empatia também facilita o autoconhecimento (de quem escreve e de quem lê). (VILAS BOAS, 2003, p. 14).
\end{abstract}

Ao contextualizar a história e cultura afrodescendente da comunidade e, oportunamente, evidenciar aspectos relatados que tenham sido invisibilizados pelo discurso 
dominante, busquei preservar as marcas da oralidade. Isto porque, além do caráter narrativo-descritivo, este tipo textual nasce no âmbito das pesquisas qualitativas em Ciências Sociais no termo "Histórias de Vida", modalidade que "dá atenção total ou parcial às narrativas sobre as vidas de indivíduos ou de grupos sociais, visando humanizar um tema, um fato ou uma situação contemporânea" (VILAS BOAS, 2003, p. 16-17). E, num exercício máximo do compromisso com a relação de confiança estabelecida com as/os entrevistadas/ os, os perfis culminaram na preservação das histórias, identidades e sentimentos contados.

Concordando com o jornalista, a criação, a escrita, o discurso são processos multidimensionais que, como argumentado supra, possuem forte carga política, ainda que implicitamente. A escrita dos perfis biográficos foi um ato que corrobora a urgência das pautas relativas à justiça social no Brasil, e é também uma síntese de memória, conhecimento e sentimento - caractere incompatível às métricas da modernidade que, em seu discurso, coisifica e mina a humanidade dos seres.

Diálogos transcritos dispostos à mesa, lidos, escutados, uma, duas, três vezes... Foi este o ápice solitário da escritora - e, creio, daquelas/es que se põem a exercer o ofício -, a ebulição das vozes e a escolha das palavras a fim de que façam do texto não produto, ou resultado mas leitura por essência e manifesto por vocação. O amplo conteúdo abordado foi sendo lapidado à medida que percebi uma inclinação maior ou mais sensível de cada entrevistado/a em relação a determinado tema. Escrever os perfis foi um processo mais complexo e conflituoso do que esperava 
enfrentar. Escrever é um processo de escolha, se leio algo, o que me inquieta é o que ficou por existir, por ser verbalizado, transcrito. Volta Miúda me inspirava em muitos aspectos e, encontrar o caminho que me levava aos objetivos obliterados da minha pesquisa foi um processo árduo de lapidação... Sobretudo para quem, na compreensão da sua interseccionalidade, vê imbricadas as relações do ser que relata memórias e externaliza sentimentos, de forma que os "aspectos históricos e culturais da comunidade de Volta Miúda" resistiam ao cumprimento do trabalho, pois o excediam.

Os vínculos criados, fortalecidos, aumentavam a responsabilidade sobre o processo de escrita. Pois, o compromisso - antes apenas acadêmico/social - agora perpassava pela afetividade entre nós. A razão política que me trouxe até aqui sofreu essa catálise. A minha caminhada acadêmica, graduação como bolsista, especializações (a primeira também cursada graças a uma bolsa de estudos) e agora o mestrado, é, sobretudo, fruto de um processo de inclusão social de que fui beneficiária e que me informa o compromisso para com os meus pares. Esta é também uma forma em que resisto ativamente, na luta por equidade, por respeito e por justiça social. Cada perfil implicou uma ebulição de sentimentos diferentes, porque evocam, também, significados e experiências que remontam a pluriversos particulares de sentido. Como não poderia deixar de ser, a apresentação de cada perfil se firmou em um núcleo temático que, conforme Sérgio Vilas Boas (2003), pode se tratar de uma circunstância, lembrança, característica ou, até mesmo, da interação estabelecida para com a autora e do/a narrador/a com a sua memória. 
Pôr-me a escrever os perfis não causava medo, mas a responsabilidade desta tarefa obrigou-me ao exercício de transformá-la não no fim, mas em fundamento guia para a minha sensibilidade. Responsabilidade e compromisso para com os sujeitos, amigas e amigos e suas memórias. Para com aqueles seres indeterminados com quem pretendia comunicá-los. Para com a resistência que faz de mim instrumento orgânico em prol da justiça social, da equidade, liberdades e dignidades humanas. 



\section{As/os quilombolas de Volta Miúda em perfil ${ }^{9}$}

\subsection{BRASÍLIA FIRMINA}

Bisneta de Vitória, neta de Flausina, filha de Firmina Flausina. Dona Brasília nasceu em Volta Miúda, em 1933, "pôco tempo" depois que a escravidão foi proibida no Brasil. As memórias que a constituem vêm de mãos dadas com o alerta: "A gente pensa que não acaba, mas acaba sim".

- E tem jeito de não acabar?

- Tem sim. É só um só num querê abraçá o mundo todo.

O lembrar revivifica-a. Dona Brasília se apresenta como a mulher rendeira, que viu a mata e as águas em abundância, nascida e criada numa Volta Miúda que, muito além dos sombrios tempos da escravidão, rendeu-lhe cantos, ritmos e fé. Ensinou-lhe liberdade.

A bisneta da "véia Vitória" vem de um tempo em que os mais velhos eram sinônimo de conhecimento e sabedoria. Já nos tempos de hoje as coisas estão se acabando porque há muito a se falar, mas os jovens não querem escutar. Naquela 
época, as crianças, curiosas, rodeavam as conversas, observavam de longe - "minino novo era inteligente" - tentavam aprender com quem já tinha vivido muito.

E foi assim, observando, que Dona Brasília se tornou a mulher que testemunhou tempestades serem acalmadas com canto e dança. Chovia muito, trovões e relâmpagos tomavam o céu quando a bisavó Vitória se vestiu para conversar com o tempo. Com um pano amarrado na cabeça, uma toalha branca, para sustentar uma bacia com pedra dentro.

Dona Brasília não entendia a língua, mas assistiu ao diálogo entre a "véia Vitória e a truvuada"... e se passava assim: mulher e tempo conversavam, ela lhe pedia que se afastasse e os trovões iam embora, ficavam mais longe, longe... até que não se ouvia mais nada.

Aquela língua permaneceu desconhecida para a criança Brasília, mas ela aprendeu com a "véia Vitória", uma ex-escrava, a conversar com a natureza, respeitá-la - aprendeu que, afinal, "Deus dexô o mundo muito grande, que dá pra tudo quanto há vivê".

Os olhos reflexivos da mulher que viu uma lagoa encantada falam sobre outro tempo. "Tudo assim existia, mas agora o século já mudô que a gente nem sabe o dia". A lagoa encantada ficava para o lado de Naiá, e não secava nunca. Lá, os 'embreves' davam significado à vida e à morte.

- O que que é embreve? - Dona Brasília se pergunta em voz alta, como quem revela uma informação secreta, dividida apenas entre amigos. Contando a história de uma velhinha doente, ela fala sobre a oração copiada dentro de 
uma bolsinha de pano - o embreve - que, jogada dentro do olho d'água, desceu, e lhe definiu a hora da morte. Ao saber que o embreve fora entregue, "aí se virô de costa e só espichô, foi embora, só fez entregá, morreu". Sem pesar, nem dor, a partida é relatada como resultado do cumprimento de uma tarefa, uma etapa. E, por que não, de um tempo.

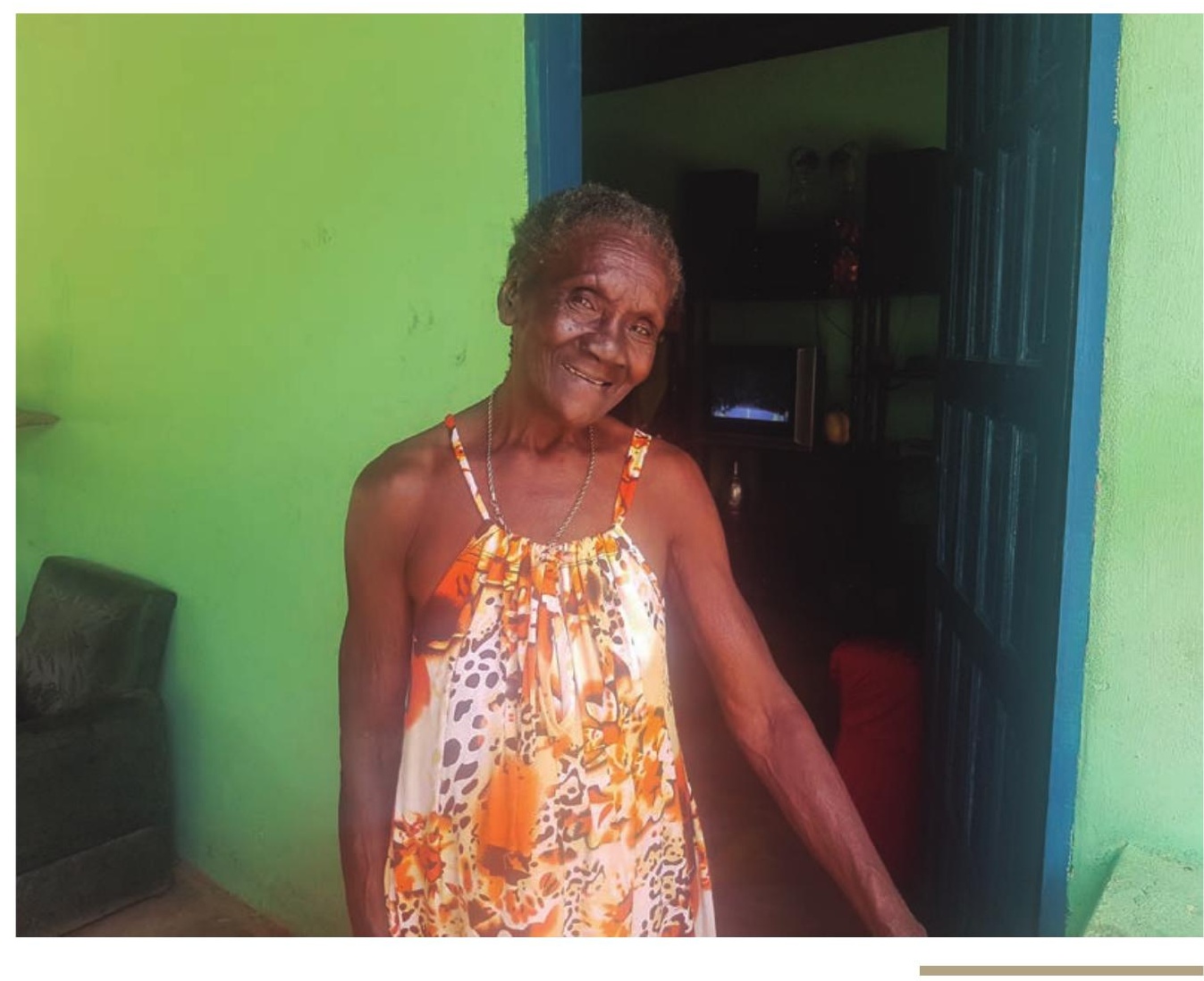

3 - Brasília Firmina (2019). 
A cena verbalizada com os olhos fixados no horizonte diz muito mais sobre a beleza do lugar, quase posso vê-la, mesmo agora. E como era linda a lagoa encantada. "Nunca secava, minha sinhora, quando ficava desse lado que olhava para o lado de lá os bichinho tava pequenininho". Enorme. Mas o século é outro, nem se sabe o dia, e, "Deus me perdoa, que não existe mais Mãe d'Água". Pesar.

A moça que levou o embreve contou para Dona Brasília: Mãe Xandinha que ensinou como salvar a menina que foi pegar água e sumiu. Para resolver o sumiço, Mãe Xandinha ordenou: "ocê, ocê, ocê... Ocês vai lá na beira da lagoa, cêis fica bateno palma e cantano". E a menina voltou toda moIhada, veio do olho d'água e nunca mais falou uma palavra - para não contar o que viu por lá.

A música vem à tona: cantavam os escravos, cantavam os homens que trabalhavam na mata, cantavam as mulheres amassando barro, torrando a farinha e cantando - "sofrendo tanto e ainda com alegria, ainda cantava". A musicalidade também é parte integrante desta bisneta da "véia Vitória", neta de Flausina e filha de Firmina Flausina. Se ela ainda canta? "A gente sofreu dimais, num era escravo, mas sofreu muito".

A lagoa que era encantada virou terra. E não existe água lá, imagina no rio. O lugar que Mãe d’Água entrava para sair na lagoa - que era tão lisinho e profundo o caminho acabou com a modernagem, mudando gente e capinando e plantando e o eucalipto puxando a água, e mudando gente e capinando e o eucalipto puxando a água. Sim, Dona Brasília ainda tem muitos motivos para cantar. 


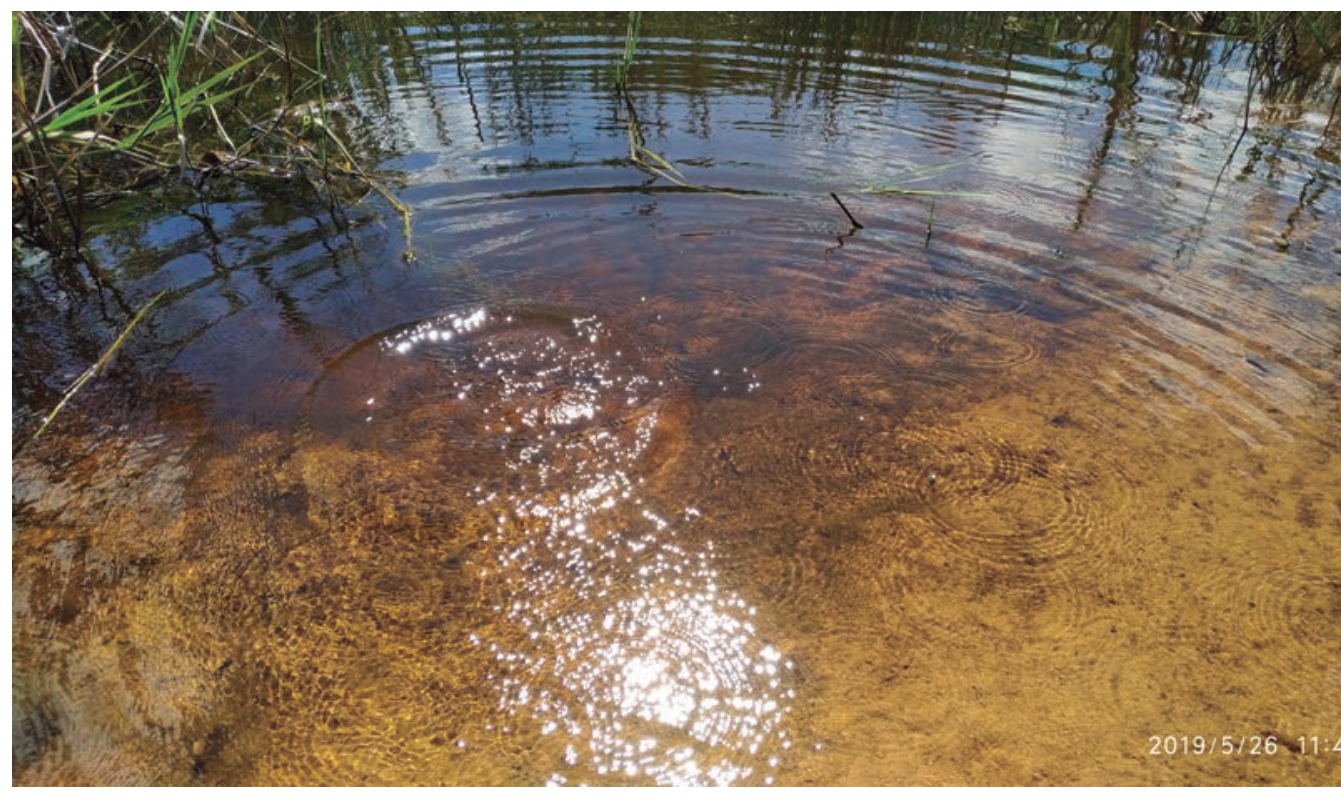

4 - llustração da

lagoa (2019). 


\subsection{MANOEL DE DELFINA}

O cantador do Ofício é filho de Delfina Joaquina Josefa e neto de Joaquina Josefa, nascida no dia em que foi declarada a liberdade aos escravizados, em 13 de maio de 1888. As bisavós e bisavôs de Seu Manoel foram libertados nesta data.

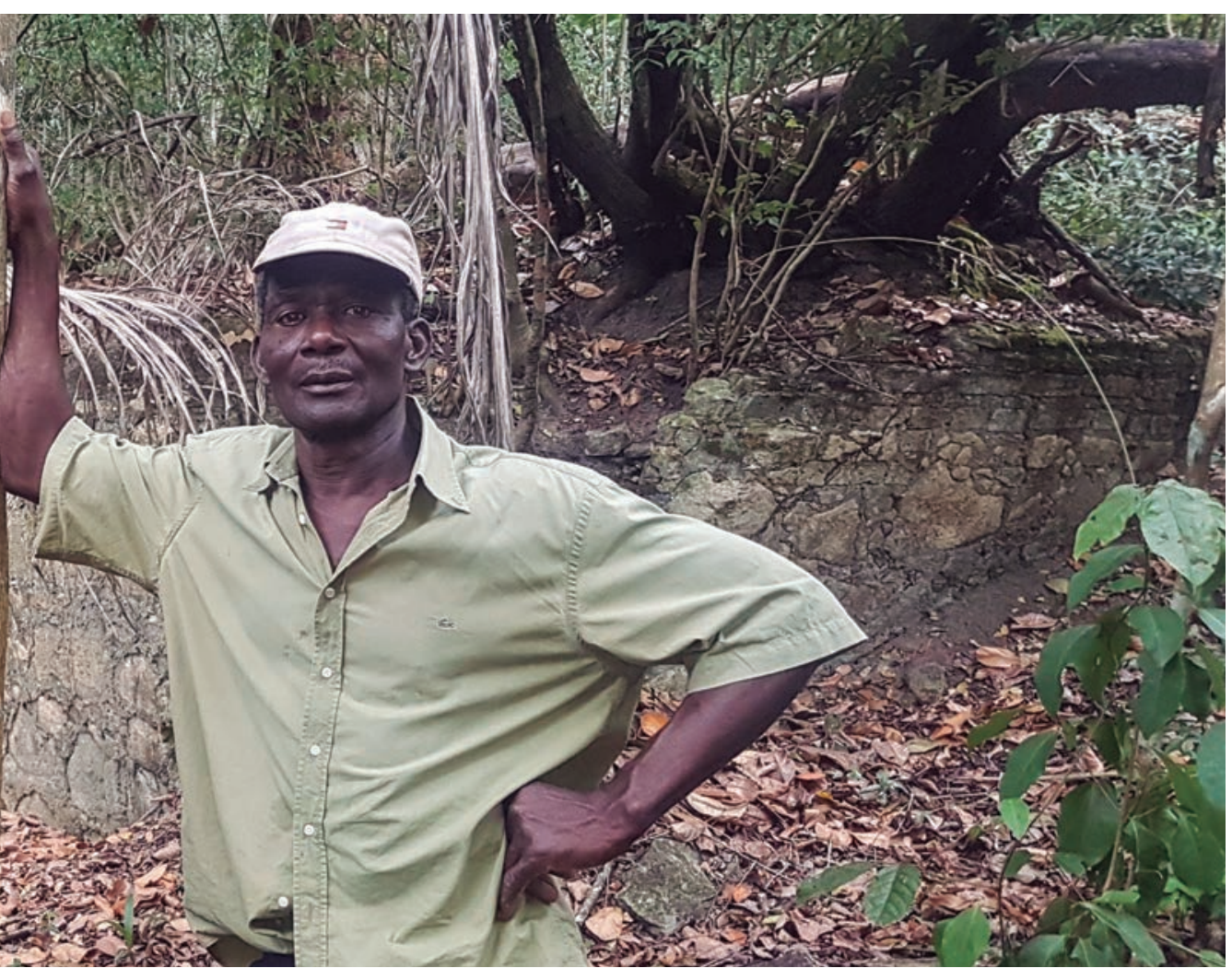

5 - Manoel de Delfina (2019). 
No dia em que visitou as ruínas da senzala, 130 anos depois daquele dia, refletiu: "isso aqui foi os escravo que fez". Arcos em pedra, um canal que desemboca no rio Peruípe, a escadaria em pedra que nos leva a um terreiro. Bases em pedra, em pé. Sob sangue e suor e força e resistência afinal de contas, ainda estamos aqui.

Que é ser livre? Reflito.

"Na cidade eu fico preso", Seu Manoel desafia os limites da própria liberdade.

"Cortano a conversa, eu sei cantá o Ofício". Sim, Seu Manoel Reis, que se apresenta como Manoel de Delfina - sua mãe -, é um mestre em cantar o Santo Ofício. Requisitado, se quiser tê-lo em um terço ou reza, há de verificar se já não foi convidado a outro lugar. Vão até ele, buscam-no para a realização desta sacralidade - desta arte - que aprendeu ainda jovem, sozinho.

Aprendeu de cor, ninguém ensinou. $O$ rezador adiante, e ele observava atento. Aprendeu. Pediu para Celestino a oportunidade para rezar, "não, assim não aprende não". Mas Seu Manoel aprendeu sem que Ihe ensinassem.

Um dia, depois de cantar folia de reis o dia inteirinho na Festa de São Sebastião, foi surpreendido: "é pra você vim cantá reza mais Cassimiro". Desse dia em diante não parou mais, Nanuque, Teixeira, Caravelas, "eu tenho saído pra cantá reza nesses canto tudo, aprendi sozinho".

A Folia de Reis aprendeu quando ia para a casa da sua avó Joaquina passar uns dias. Saía a Folia cantando com a caixa e o pandeiro, oito, dez, 12 foliões... juntos iam às casas 
convidando para as festas de santo. "Tem a festa de São João em Juerana, a festa de Santo Antônio em Caravelas, tinha a de Nossa Senhora da Piedade em Helvécia, de São Benedito em Nova Viçosa".

Homens, com caixa e pandeiro, cantando e brincando faziam a sua religião. Religavam-se a Deus recebidos por seus pares, em comunidade, em oração e em comunhão.

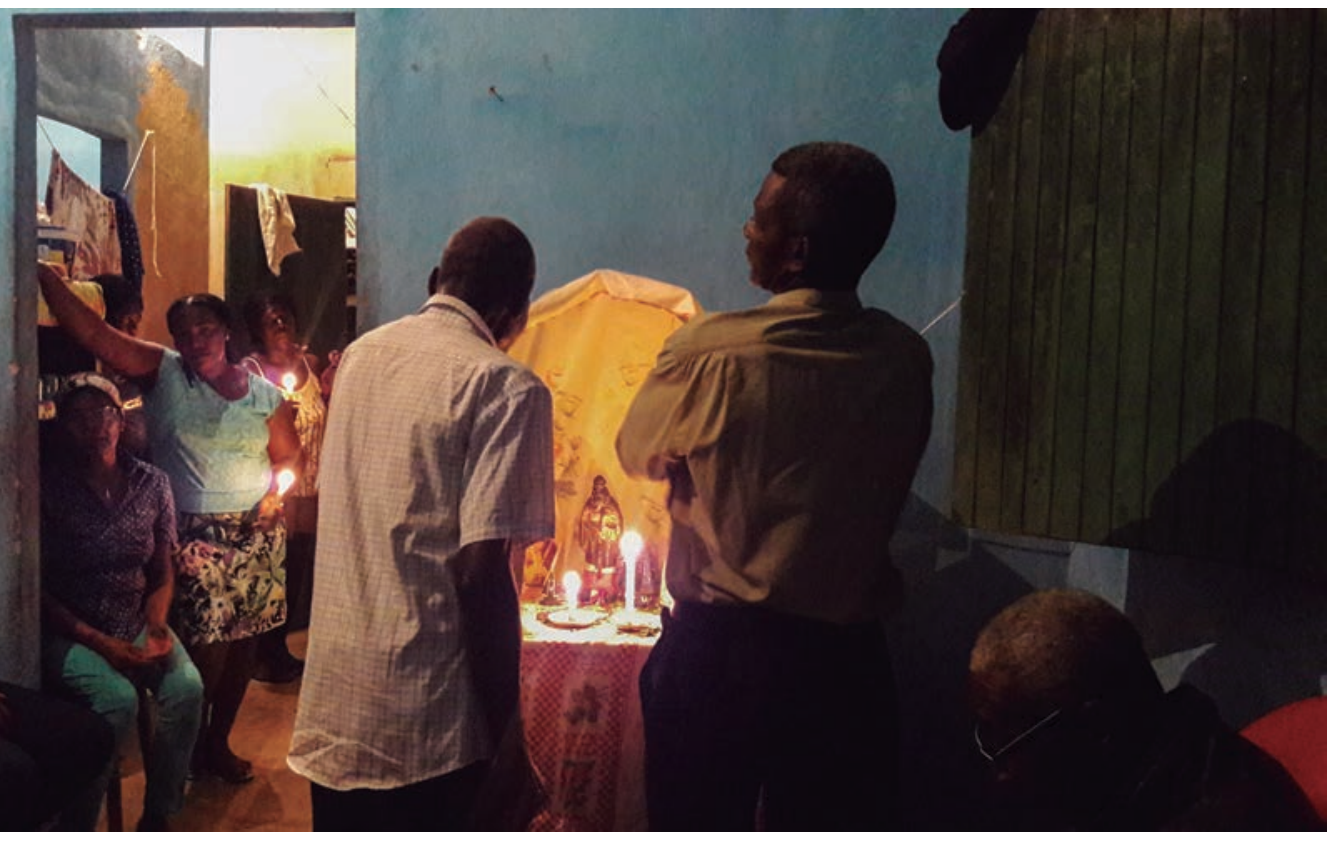

6 - Manoel de Delfina rezando $O$ Santo Ofício (2018). 

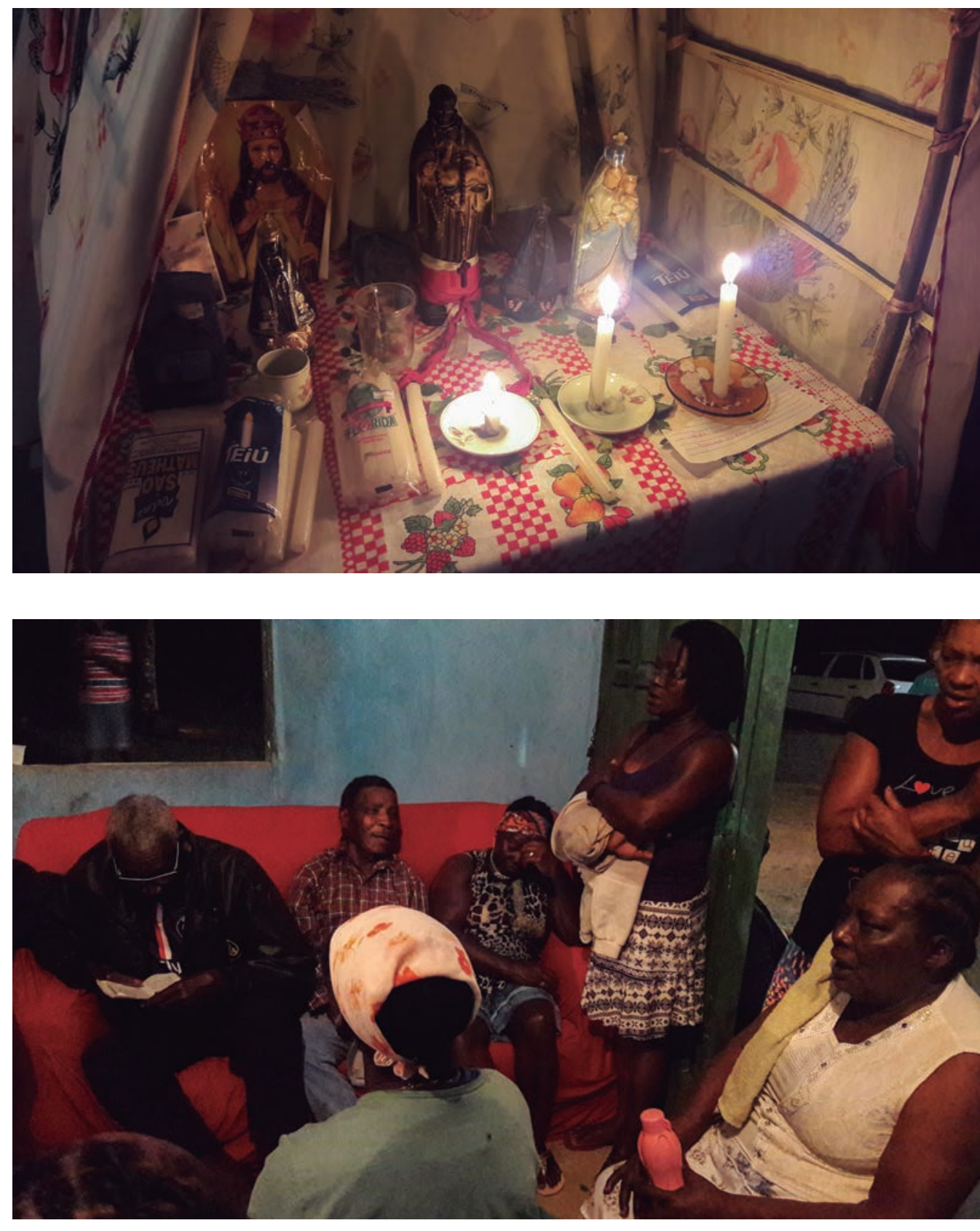

7 - Altar, reza do

Santo Ofício (2018).

8 - Comunidade, reza do Santo Ofício

(2018) 


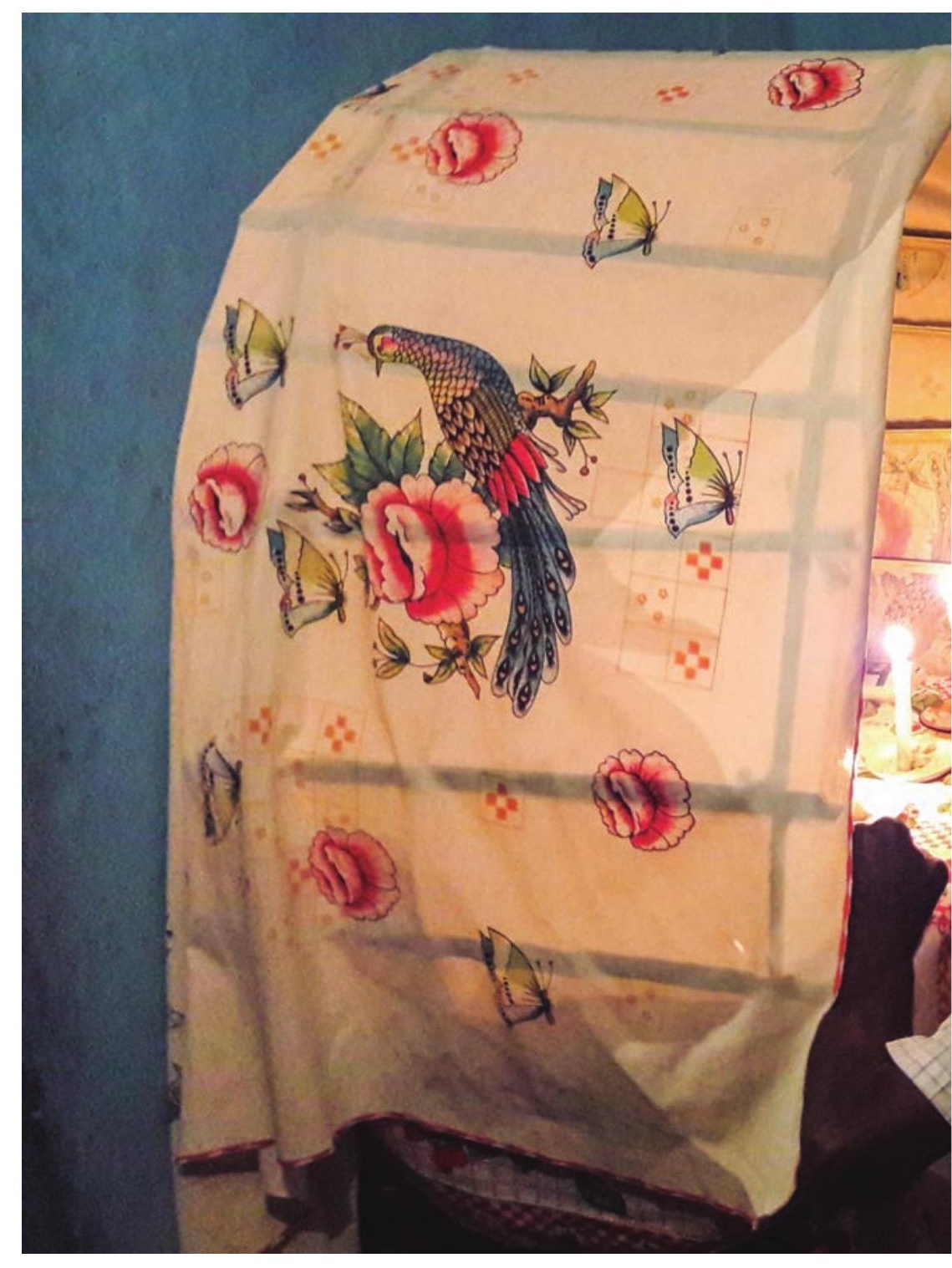

92 


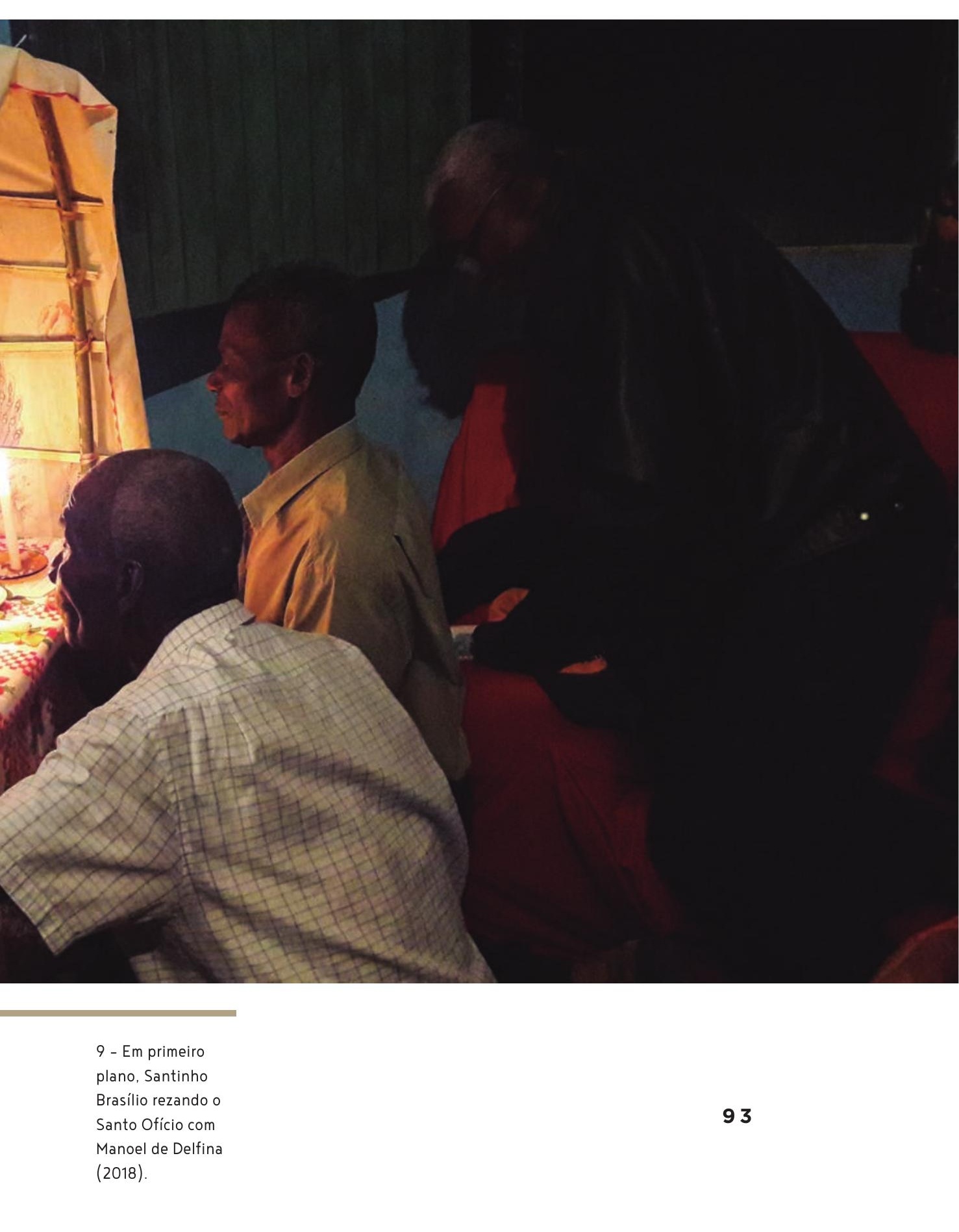


Seu Manoel é um homem de fé. Dona Delfina, sua mãe, viveu graças a ele. Quando pouco mais nova, adoeceu. Não comia, não bebia, não falava. Levaram-na ao hospital em Helvécia, depois ao Santa Rita em Teixeira de Freitas. E os médicos insistiam: se não internar, ela piora. Para Manoel, de tão ruim a situação, a piora ia levá-la à morte. E não parecia certo deixá-la se acabar em hospital.

Em casa, "assim de gente oh, cheia!", achou melhor falar com os irmãos Casimiro e Joaquim para deixar animal preso, preparar-se para dar a notícia. Mas, o destino outrora definido, agora podia ser outro - afinal, há muito tempo eram donos da liberdade, com a bênção de Deus.

Mês de maio, fazia frio, eram 3 horas da manhã quando Seu Manoel se levantou da mesa - "tem coisa que é Deus que bota na cabeça da gente". "Maria", disse à irmã, "eu vôlá na casa daquela muié rezadeira”. E foi, afinal, "Deus que envia a gente".

O nome da rezadeira era Maria de Florência - chamada até de Maria Macumbeira. "O sinhô aqui é nuvidade muito grande, num é?", disse ela. Era mesmo. "Purque eu tô com minha mãe lá tantos dias, já fui no médico e tal", o dia já estava amanhecendo quando a rezadeira tomou a decisão: "me chamou e disse: faz isso, e isso, compra óleo de amêndoa, óleo de rizo, a folhinha de poejo, alevante, o que era pra fazê, eu fui fazeno".

Manoel de Delfina chegou em casa ao meio-dia com a reza pronta, explicou conforme Maria de Florência mandou fazer. E, depois de mais de 15 dias sem conversar, só pela mão dos outros, Delfina soltou a fala, estava com fome. E sarou, seguiu os remédios e viveu. Morreu com 95 anos. Seu Manoel é um homem de fé. 
"Com respeito a quarquer um", mas também com o humor - afinal "se a gente não fizé graça morre à toa, viu?".

A ausência da visão não afeta a sua capacidade de ver - sentir - o mundo.

Domingos Serafim não enxerga "desde os tempo do URV". Começou a "senti das vista" no início da década de 1990, foi a vários médicos, mas nenhum deles conseguiu curá-lo. Ele conta e não lamenta: "Tô conformado com Deus, é, parado eu também num fiquei não, lutei muito". As transformações do mundo à sua volta são sentidas em outras dimensões, e permanece vivaz o cenário da Volta Miúda do século passado.

Pai de oito filhos, está "no poder de tataraneto", casou-se com Tereza Paulo Serafim, filha de Cicílio Paulo, mas esta também lhe falta. Estavam há quase meio século juntos quando ela morreu, num acidente de carro. "Mas eu não gosto nem de alembrar fia, porque é só alembrar parece que tô vendo o caixão de minha véa saindo agora... ai, Deus. ... Tudo que eu tenho aqui foi eu mais ela que fez". Tereza também era nascida e criada em Volta Miúda, "a fazenda dela era daí do outro lado, ali no pé de coco".

À frente não há mais pé de coco, somente pés de eucalipto. Antes, dava de tudo, "só não dava o que não planta.". Mandioca, muito abacaxi, laranja, cana, banana e tinha muita mata virgem, a Volta Miúda era terra rica, toda a redondeza até o Rio Peruípe. "Mas agora, se você plantá sua rocinha de maxixe, periquito come tudinho. De primeira não dava isso, né? Mas agora tá tendo esses inseto, mas também tem razão porque por eucalipto, quem vai comê só pau?". 
Aos 82 anos, Seu Domingos Serafim tem "sentimento" por muito do que não há... Mas ele gosta de relembrar o passado, "quem é que não gosta de uma coisa boa?". Foi-se a companheira, irmãos, filho, a visão, a fertilidade... Pergunto se Volta Miúda já foi uma comunidade feliz. Ele responde sem pestanejar: "É feliz". E, ao seu lado, diante do mar de eucaliptos, esforço-me a ver o mundo pelos olhos de Domingos Serafim.

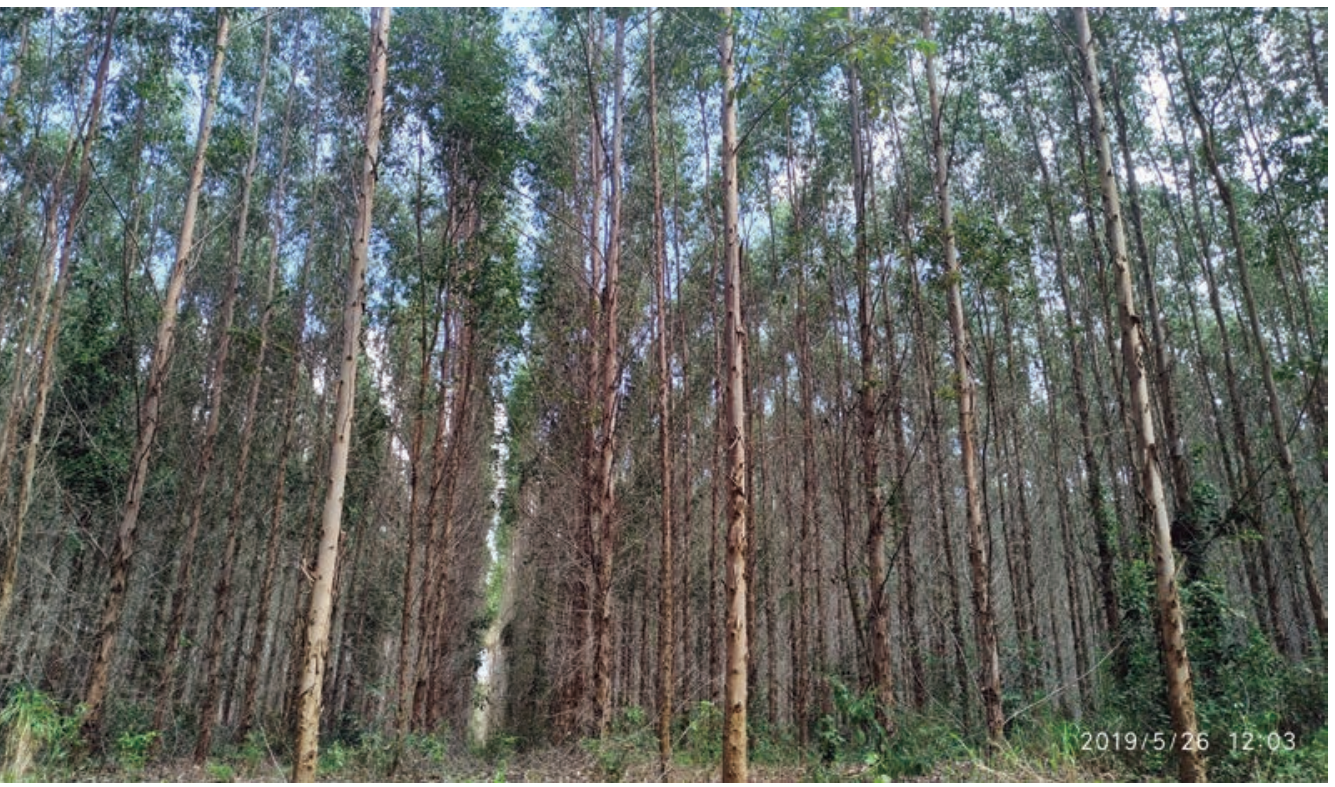

12 - Horizonte de eucalipto (2019). 
"Quando eu tomei entendimento de gente, ainda topei o cheiro dos escravo", criado na barra da saia da avó Júlia, ouviu muitas histórias, histórias que parecem aprimorar o sabor da liberdade. "Nasci e criei na Volta Miúda, e é daqui pro cemitério", Seu Domingos Serafim não quer ir a outro lugar, a sua vida está enraizada ali, há muitas gerações. Sua fala soa como afirmação e prece, afinal, não faz muito tempo, os pais dos seus avós sofreram nas mãos dos senhores latifundiários escravocratas que, naquelas terras, os escravizaram.

"Vó Júlia falava que com escravo era assim: botava, futucava formiga preta e botava criança lá, pra formiga preta mordê... não podia chorá, é verdade, escravo disse que foi duro, e hoje tem, tem uma catingazinha um cheirozinho de escravo". A senzala ficava ali pertinho do rio Peruípe, assim contava o pessoal mais velho quando saía para pescar. $O$ tempo de castigos passou, mas a ameaça à liberdade de permanecer em seu lar ainda o assombra, mesmo agora, ainda é possível sentir o cheiro.

A vó, que fazia "aqueeeele dendê", alertava os netos, "Eu tenho muita história, eu e meus primos-irmão". E Seu Domingos aprendeu, é "respeitadô do direito de quem merece". Foi ouvindo e vivendo e participando que aprendeu que a barbárie não desumaniza, a menos que se anseie o lugar do opressor. "Escravo trabalhava embaixo de taca, dona Raíssa. E se criancinha chorasse mãe não podia pegá, ia direto pro forno. É coisa de doido, né?". Seu Domingos, pondera: "Homem de capacidade num grita com outro, porque só se grita com gado". 
13 - Gente não é gado (2018). 


\subsection{BERTA D'AJUDA}

A neta da parteira Dominga é sabida que só vendo diz que a memória não é boa, que não sabe contar história... Mas Dona Berta d'Ajuda sabe contar história com a força e eficiência de quem trabalha na roça, de quem sabe fazer farinha, moqueca, dendê e até casa de taipa.

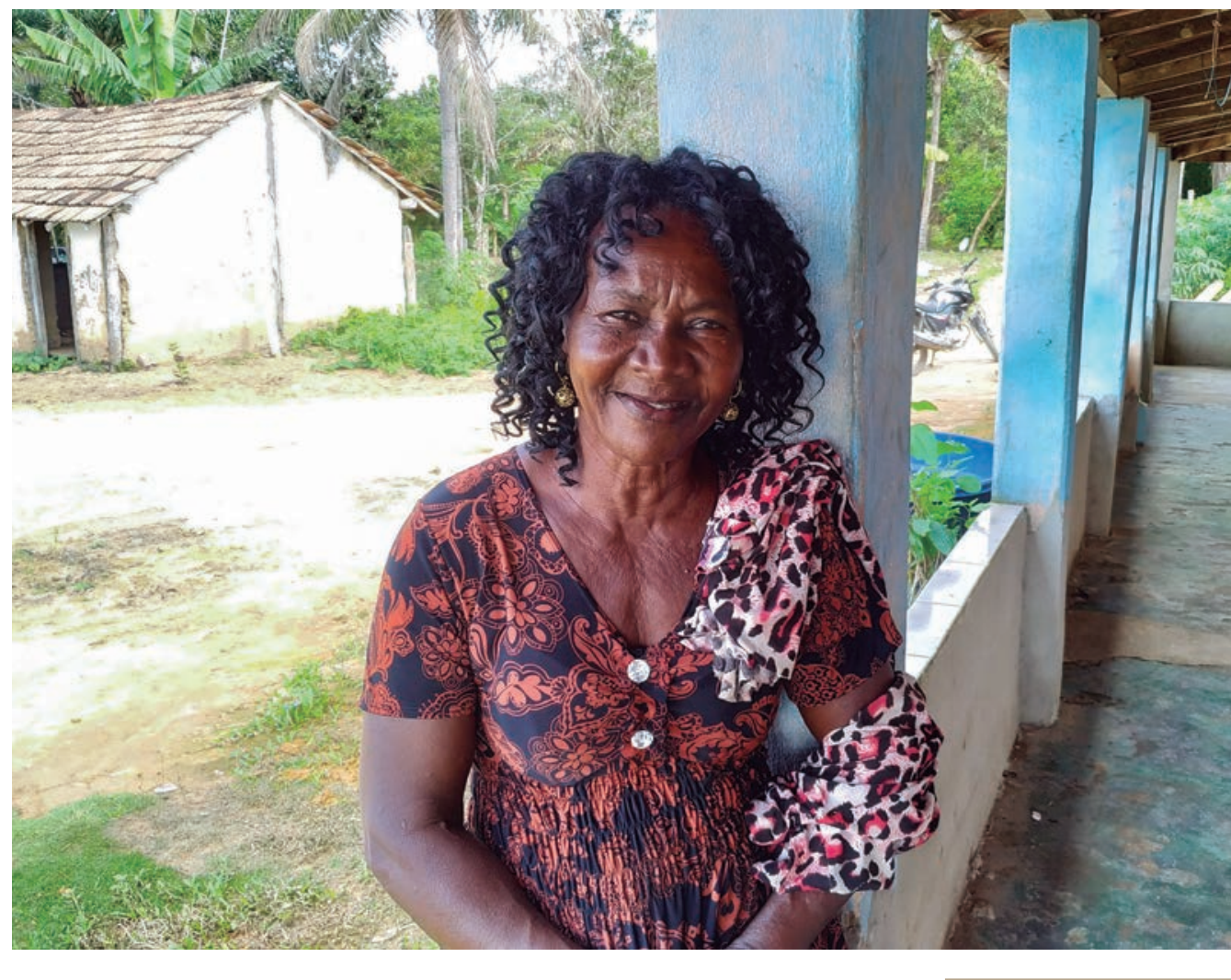

14 - Berta d'Ajuda (2019). 
Descascando coco para fazer beiju, a timidez vai ficando para trás e ela confessa: "Na verdade, ai dos homi se num for as muié... As muié é que é guerrera". Com voz firme, ela conversa sem parar de trabalhar.

A vida é dura, mas é muito bonita também... Ir à rua, só para vender as coisas e passear, bom mesmo é viver na roça, onde tem muita gente entendida e tudo é "muito bonito, é sim, dona menina".

A Volta Miúda é o lar de mulheres valentes, que enfrentam a batalha, com certo orgulho e melancolia - "se as muléficar decaída vai ficar sozinha à toa". Todo sábado Dona Berta está na feira, vende beiju, tapioca, feijão-de-corda, aipim, "de tudo que a roça produzir". Vende o que planta e as mercadorias do filho.

"Hoje a gente vive mais sozinho", a saudade de Dona Berta fala de uma Volta Miúda diferente, dos tempos da infância e juventude, quando "o pessoal era muito unido, era muito unido, agora não é tanto mais assim. É unido, mas num é igualmente". Ela aprendeu a ajudar a quem precisasse, pois antigamente era assim, "mais hoje em dia os novo só qué sabê do dinheiro".

Todo mundo ajudava a todo mundo. Quem precisasse ia chamando: "Olha, eu vô fazê um negócio tal dia, assim, assim"... No dia marcado, a panela de feijão ia para o fogo, carne, "tudo chegava, trabalhava, quando dava na hora de almoçá, almoçava, tomava café e de tarde ia embora". Se ficasse serviço para o outro dia, ajuntavam-se novamente. "Era bonito". 
Dona Berta sente saudade do tempo da casa de palha, - quando "todo mundo ajudava, o pessoal perdia tempo pra ficá a semana toda ajudano você fazê qualquer coisa" -, Dona Berta sente saudade do tempo em que o dinheiro ainda não havia corroído as relações - "ajudava de graça, hoje em dia, ninguém qué disprendê hora pra ajudá". Mas ela garante que o povo ainda é unido, mesmo que não seja como naqueles tempos. "Era muito unido, agora num é tanto mais assim. Intão é, só num é igualmente", e persiste o orgulho da sua terra e do seu povo.

Foi vivendo com os seus, participando desses ajuntamentos, que Dona Berta aprendeu a fazer casa de barro, aprendeu a fazer beiju e moqueca, cuidar da roça e fazer dendê. Aprendeu vivendo.

A Volta Miúda tem muita gente sabida. Dona Berta me olha como a quem "ainda tá fedeno a leite", e conta: foi sua avó que fez o parto dos seus filhos. "Todos cinco passou na mão dela", e naquela época ninguém morria, pois nascia na mão das mães que geravam a comunidade. "Era tudo sabido, minha avó Dominga tinha idade, era uma partêra boa, morreu velha já. Chega a hora pra todo mundo, num tem jeito". Se antes os pais que governavam os meninos, hoje os tempos já são diferentes... Mas os netos que moram com Dona Berta estão crescendo direitinho, estão aprendendo que não se vive sozinho, e que pra se morrer sozinho basta muito pouco. "Ai de mim se num fosse esses menino, de vez em quando tem as malandrage deles, mas me ajuda dimais da conta".

Dona Berta é uma mulher inteligente e acha que, se os novos não aprendem o labor dos velhos, é porque ou lhes 
falta interesse em ouvir, oportunidade para viver ou interesse em permanecer na lida da terra. Mas ela garante: "a vida na cidade só presta pra quem tem bolso cheio, eu prefiro ficá na roça". A roça dá o alimento e o teto. Para quem não teve ou perdeu a oportunidade de aprender a construir seu próprio lar, Dona Berta ensina como fazer casa de barro: "Cava o chão, procura assim lugá que tem barro vermelho, e aí junta. A gente chama os pessoal, junta esse povo todo de gente, leva a vasia pra levá água, chega, põe e aí vai ajudano. Aí os homi corta o barro, tem hora que as muié caía no meio também, cortava o barro, jogava água, massava e ia carregá pá tampá a casa. O telhado era de palha, ou de palha ou de madeira ou de ternit, mas era mais de palha. Eu mesma, casei na casa de palha, e casei e morei na casa de palha quando casô, até tive os filho todinho, casa de palha".

Dona Berta fala sobre a casa, mas ensina mesmo é que os ajuntamentos - que também aconteciam na lida da roça, para capinar, colher, tratar... - eram a vida acontecendo e ensinando a meninada a ser gente e a servir... ensinando a ser comunidade. 

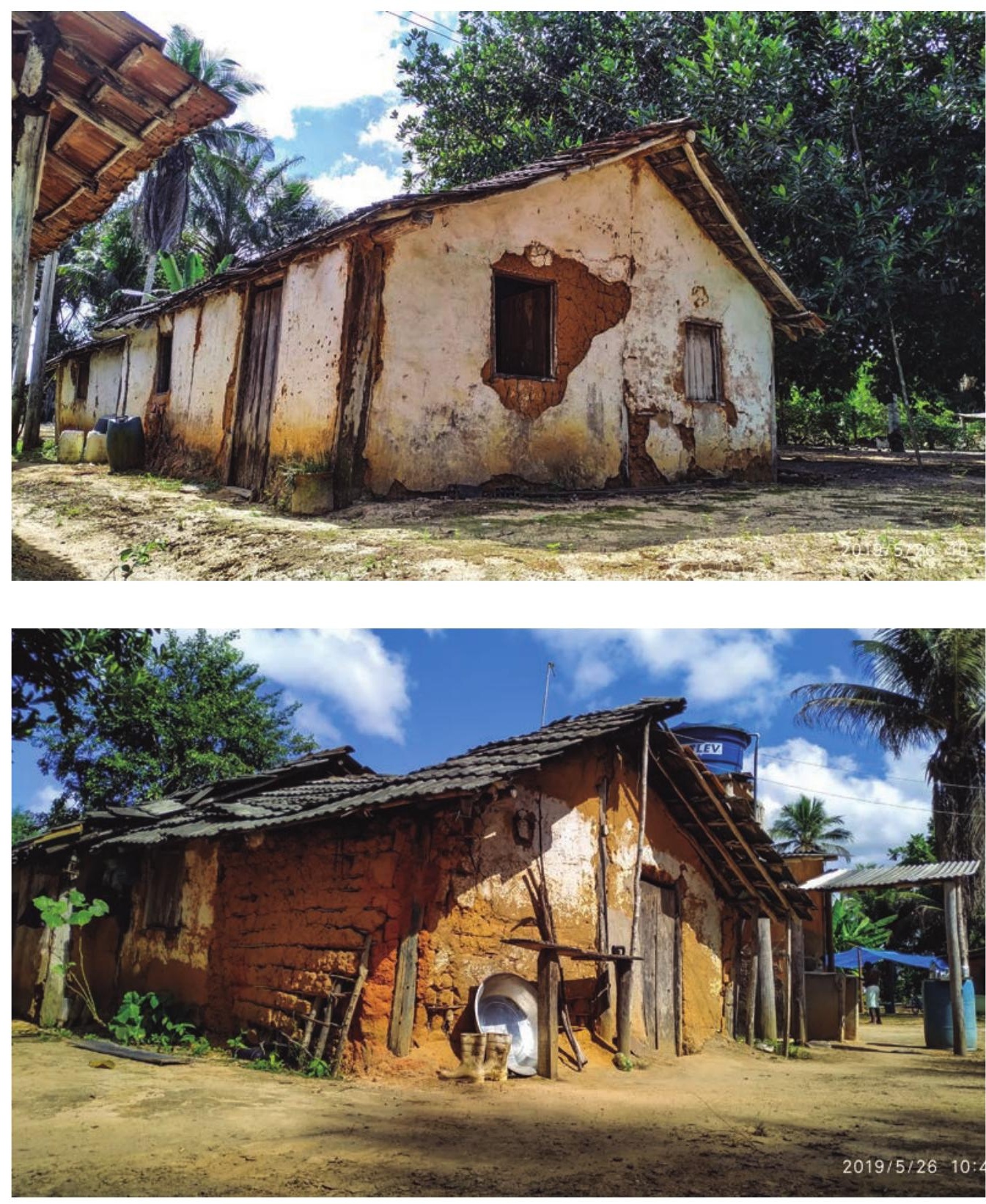

15 - Casa de Taipa

em Volta Miúda

(2019).

16 - Marcas do

tempo, Casa de 
Para ele, o mundo tem muita gente - e, por isso, falta alimento.

As máquinas substituem os homens no serviço - mas, se foi inventada, tem que funcionar. Se a mata está sendo derrubada é porque antes tinha pouca gente no mundo hoje tem muita gente para destruir. Existem ricos e pobres - e é bom que seja assim, afinal, quem ia querer "enfrentá a enxada com esse sol quente"?

"A gente acha que tá ruim, mais a coisa nunca fica bom pra todo mundo. Pra uns mais ou menos, pra outro tá bom, pra outro zero. Mas eu conservo assim mesmo, porque não tem jeito".

Seu Santinho Brasílio explica, paciente, o caos do mundo. A população cresceu, as máquinas foram inventadas e têm que funcionar - porque senão o serviço de quem as fez fica sem prestígio -, os ricos não iam querer trabalhar como negros, então tem mesmo que haver os pobres, do contrário aí é que ia faltar alimento mesmo - hoje, pelo menos, não falta para todo mundo.

"Tem gente que reclama, mais eu falei: ó pessoal, num tem jeito não", e, se não há jeito, tudo está como deve ser e, se faltam motivos para comemoração -, não tem porque ficar amuado. "É assim que é".

O eucalipto chegou, deu emprego, as máquinas vieram para fazer o serviço render mais, chegou o desemprego, a água do lago secou - "mas talvez porque chegou o tempo tamém" -, mas agora tem transporte para ir à rua, a terra não rende mais o alimento, mas tem escola... 
"Mais o resultado é conforme eu tô dizeno, quando conserta um lado, entorta outro e num jeito de consertá tudo tamém não né. Não tem as condição de consertá tudo, né. O governo não pode consertá tudo porque não tem jeito, a população cresceu muito. Então ele não tem jeito de consertá essas coisa tudo não, leva a fama... mas a coisa pra ele também é bastante peso."

"É assim que é": sem tristeza, sem pesar, nem dor. Mas também sem esperança.

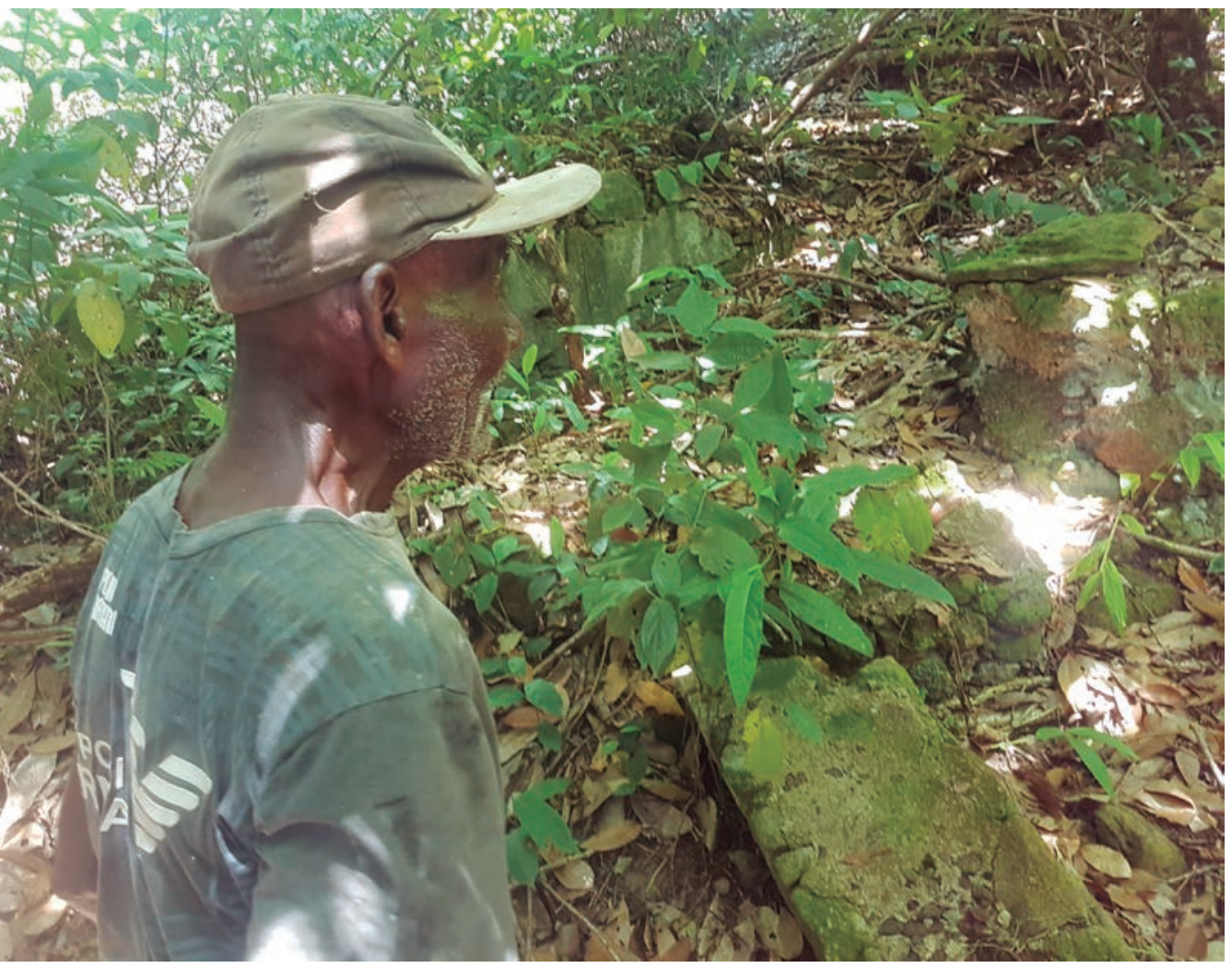


O irmão de Dona Brasília conhece o caminho para chegar ao local da "senzala", onde estão as ruínas do "engenho de fazê alambique, secadô de café, represa e roda d'água". Lá, jaqueiras e coqueiros se perdem no céu... são testemunhas seculares do labor dos bisavós e ascendentes de Santinho Brasílio.

"Tudo aqui foi feito pelos escravo" - como parte de uma história inevitável, assim como parece ser ainda hoje -, paredes de pedra vão se erguendo no meio da mata, e o que era nada faz-se significativo: "os escravo naquela época sofria muito".

Abrindo caminho na mata a facão, derrubando madeira para fazer pinguela, o vigor define Santinho Brasílio - vigor de quem trabalha e enfrenta a vida porque assim é que é, tem de enfrentá-la.

O maior enfrentamento, contudo, é a admirável substância e vida nas pedras que conformam arcos, canais... que conduzem a uma preservada escadaria e um terreiro. 


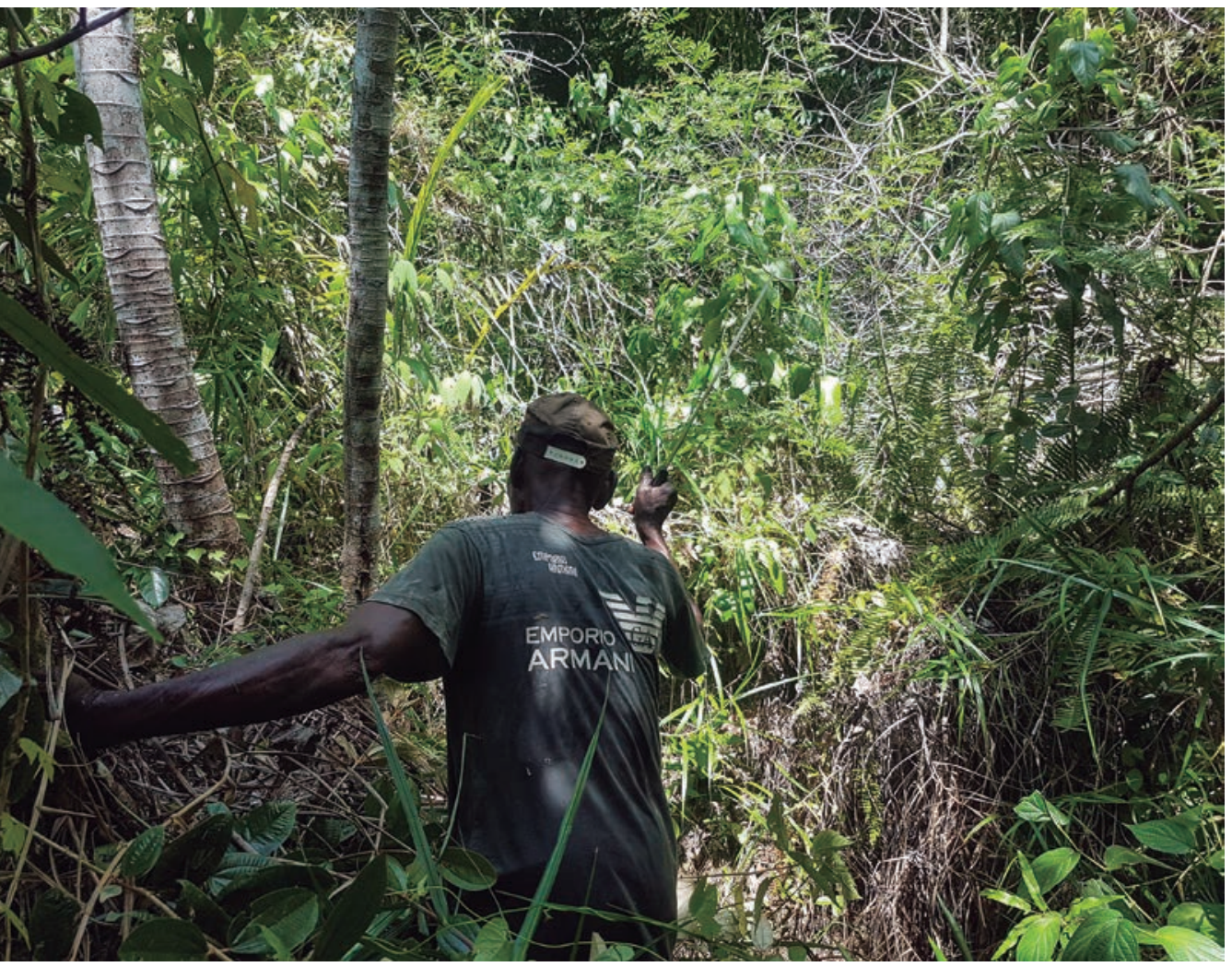

19 - Santinho

Brasílio abrindo

caminho na mata

(2019). 


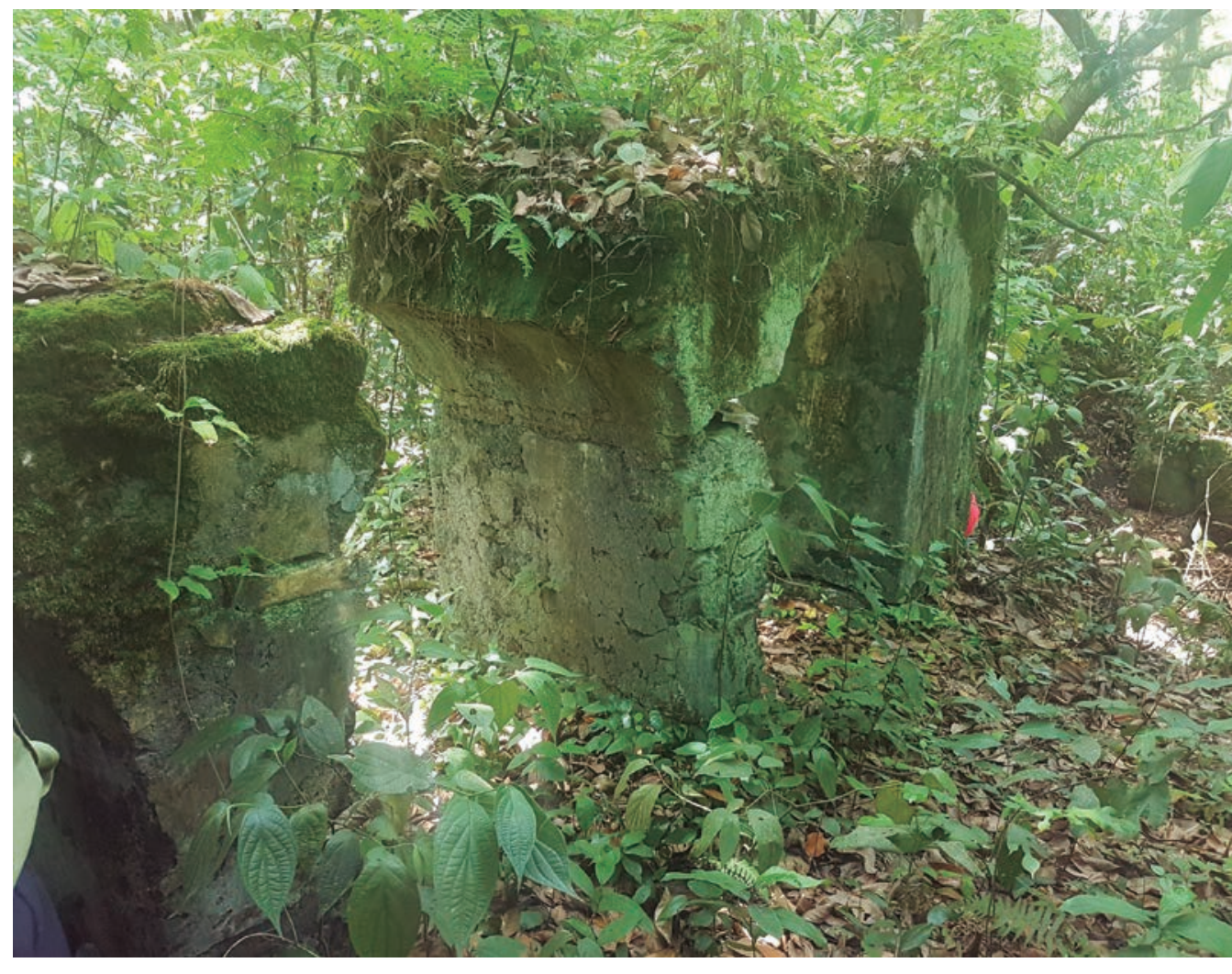

20 - Sítio

Arqueológico

Senzala de Volta

Miúda (2019). 


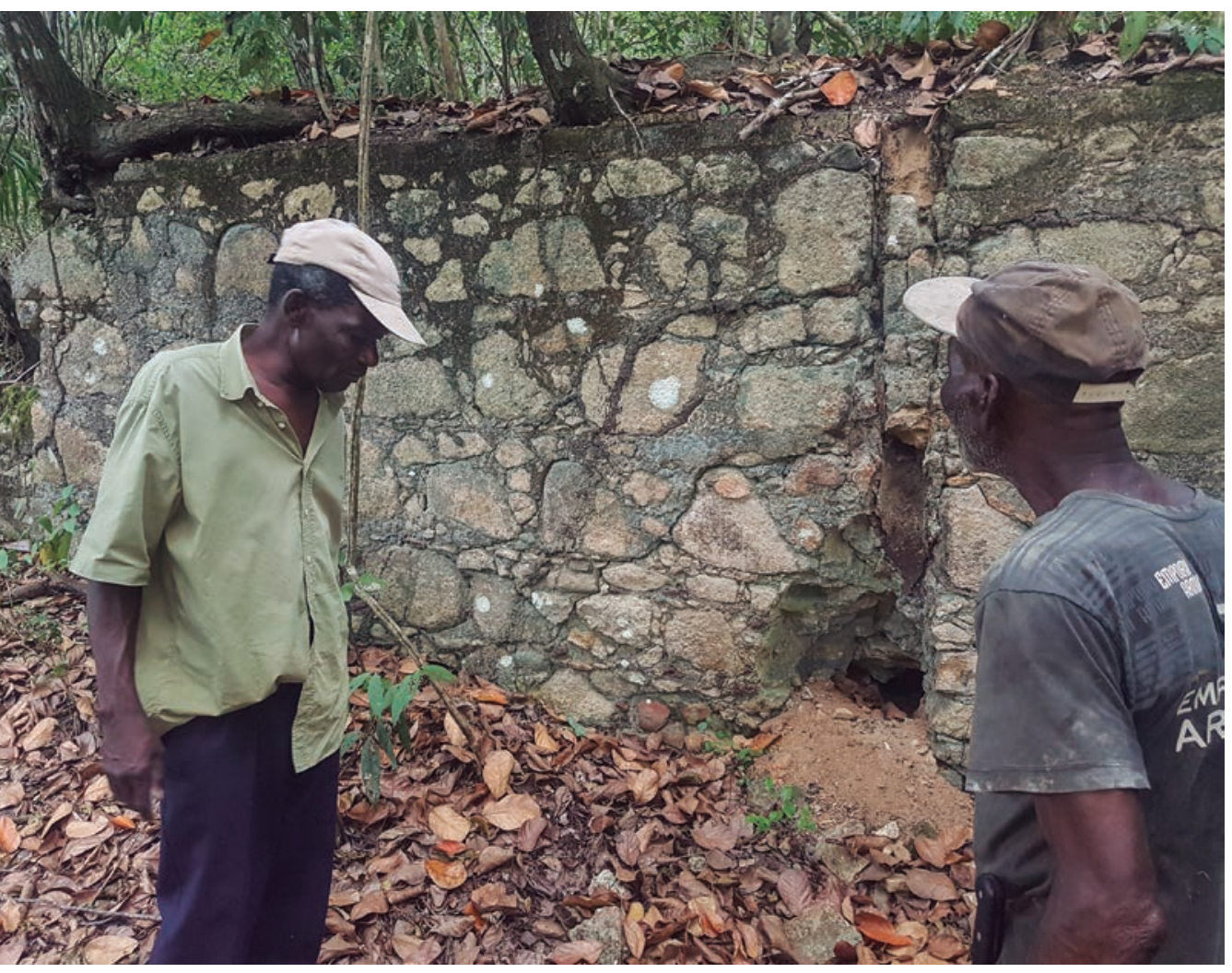

21 - Santinho

Brasílio e Manoel de

Delfina na Senzala

(2019). 


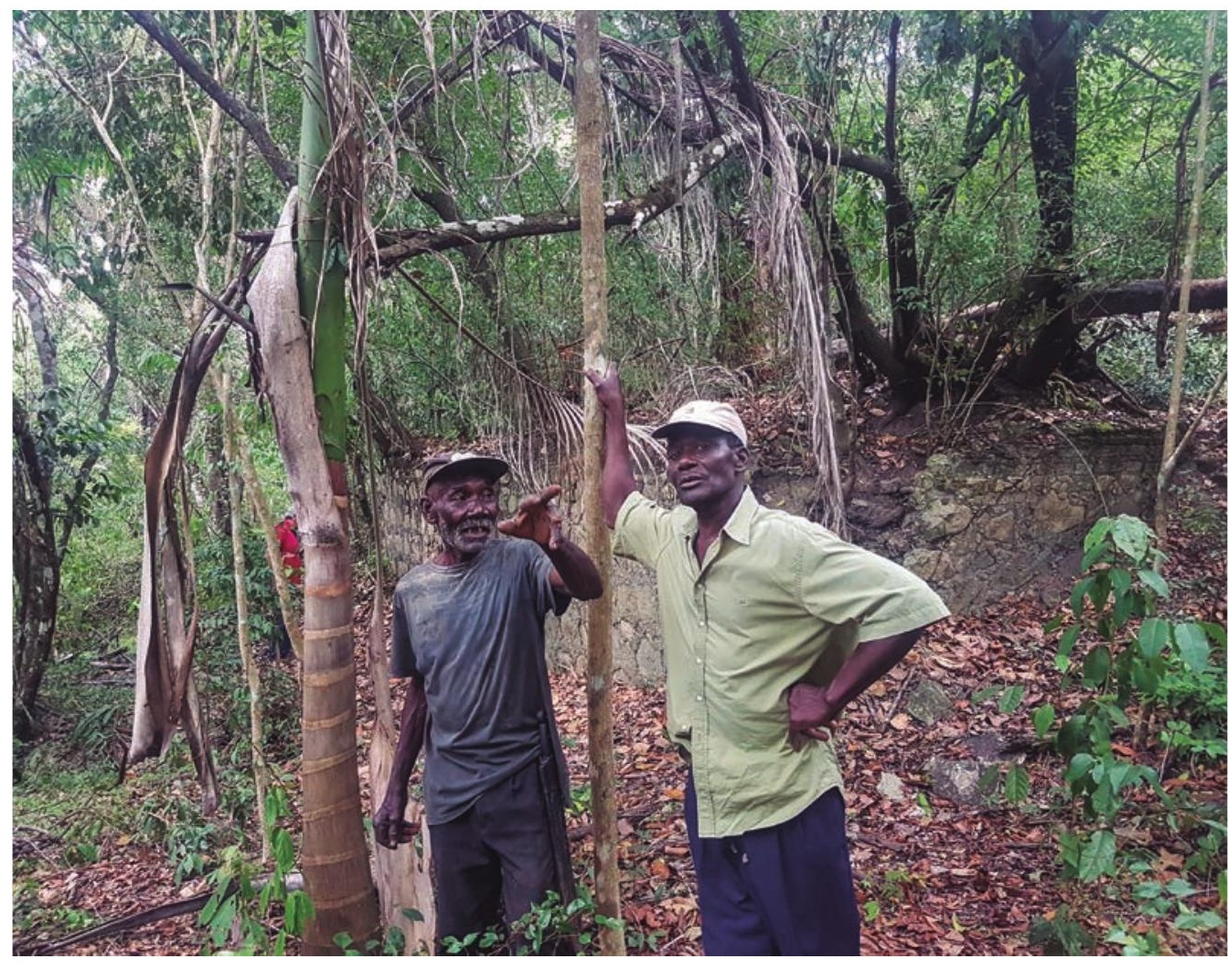

22 - Santinho

Brasílio e Manoel de

Delfina na Senzala

(2019). 
Histórias, achados, relatos de quase morte e vida da lagoa que secou e das grandes canoas que conectavam Volta Miúda à Villa Viçosa falam sobre a vida que erige a partir das pedras.

“A casa era lá ó... A casa, lá embaixo era bem alto. E era varanda, a casa tudo era varanda ao redó. A casa eu topei, mas só que não tinha gente mais, e tudo tinta azul, as parede, as madêra, tudo tinta azul", mas tudo se acabou. Havia enfeite, casa, rio e riqueza - tudo acabou.

É com o mesmo semblante ameno, dotado de certo tom de fatalismo, que Santinho fala sobre o ontem e o agora; o futuro será o que há de ser - um paradoxo de quem sente o mundo estatuado, por força do tempo ou das substâncias de vida que imobilizam e, a certo ponto, desumanizam ao tolher o arbítrio... "Tá vendo? Tudo pedra, oí ó. Tudo de pedra. A água tá fria. Água fria, só vendo. Agora tudo de pedra". 


\subsection{MIÚDA}

Miúda só no nome, ela nasceu pequenininha e isso valeu o apelido que carrega até hoje:

"Eu era miudinha, desse tamaninho... Minha mãe sempre falava, ela tinha um banco quando ela sentava ali pra cosê, e ela sentava e me botava. Chegava um e olhava por debaixo do pano: 'Ih, Delfina, essa aqui num vai criar não...o rosto dela é muito miudinho'. Aí eu fui cresceno, cresceno... começô a gatinhá, começô a sentá, aí começô andá, foi um ano, dois ano e tô eu aqui hoje".

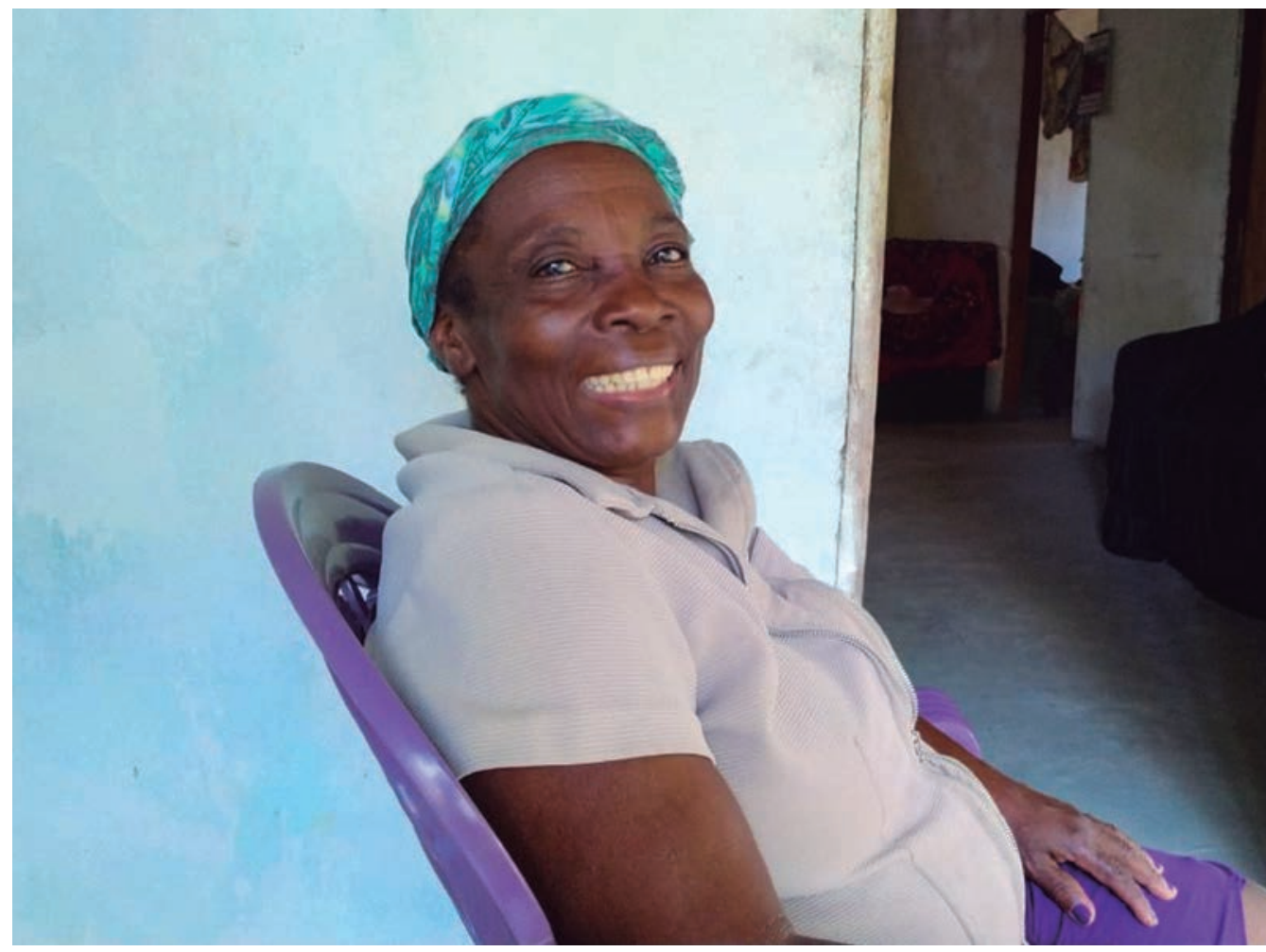


Dona Miúda é Romana Joaquina Serafim. Romana como a mãe do seu pai, José Serafim. Joaquina como a mãe da sua mãe, Delfina Josefa.

Dona Miúda é uma gigante em sorrisos (e riso) e abraço.

"Eu sou quilombola" - se apresenta. Sentada na varanda, jovial e desprendida, Dona Miúda conta sobre a família, avós e bisavós "do tempo do cativero", mãe e pai que viveram (e morreram) em casa de taipa, e dos netos a quem ela mesma está ensinando que são, também, quilombolas. Ela reconhece que na escola não ensinam sobre Volta Miúda, mas ela fala a quem quiser ouvir - assim, quem sabe, a(s) história(s) não $\operatorname{morra}(\mathrm{m})$.

"Meu neto mesmo veio esses dia, passô meio dia aqui comigo e disse assim: 'ô vó, eu num sô da família dos quilombola?". Dona Miúda antes de explicar, pediu-lhe que sentasse ao seu lado, longe do celular e da televisão, e o menino assim fez, atentamente.

“Eu falei assim: É. Você é, e sua mãe é bisneta dos quilombola. Tá me entendeno?". Dona Miúda lhe ensina que a substância da sua vida é, por princípio, sangue e sentimento, os que antes dele vieram.

Na escola, foi assim que ele contou, mas os coleguinhas não acreditaram. Então, "Ele tirô o meu foto e levô, porque ele é da sua cor e eu sou preta - e eu falei num tem nada porque o sangue é o mesmo. Tá entendeno?". Dona Miúda, mulher preta, Ihe ensinou que a cor é um retrato, mas o que o define é sua história, sua cultura, o seu povo. Dona Miúda é afeto e fé. E também é força, é o que foi, o que há e o que há de vir. Dona Miúda é resistência. 

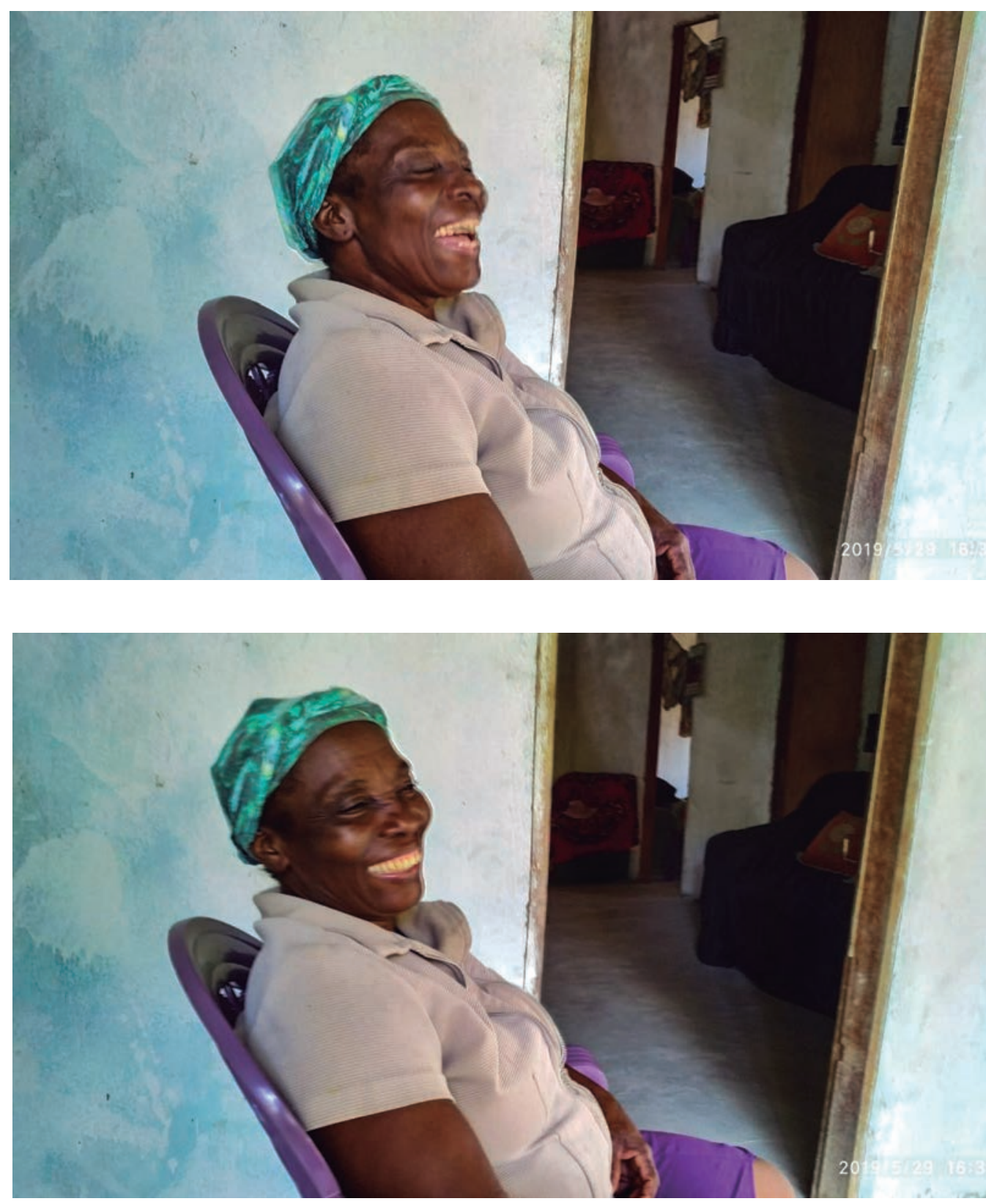

24 e 25 - Miúda

e o seu largo

sorriso (2019). 


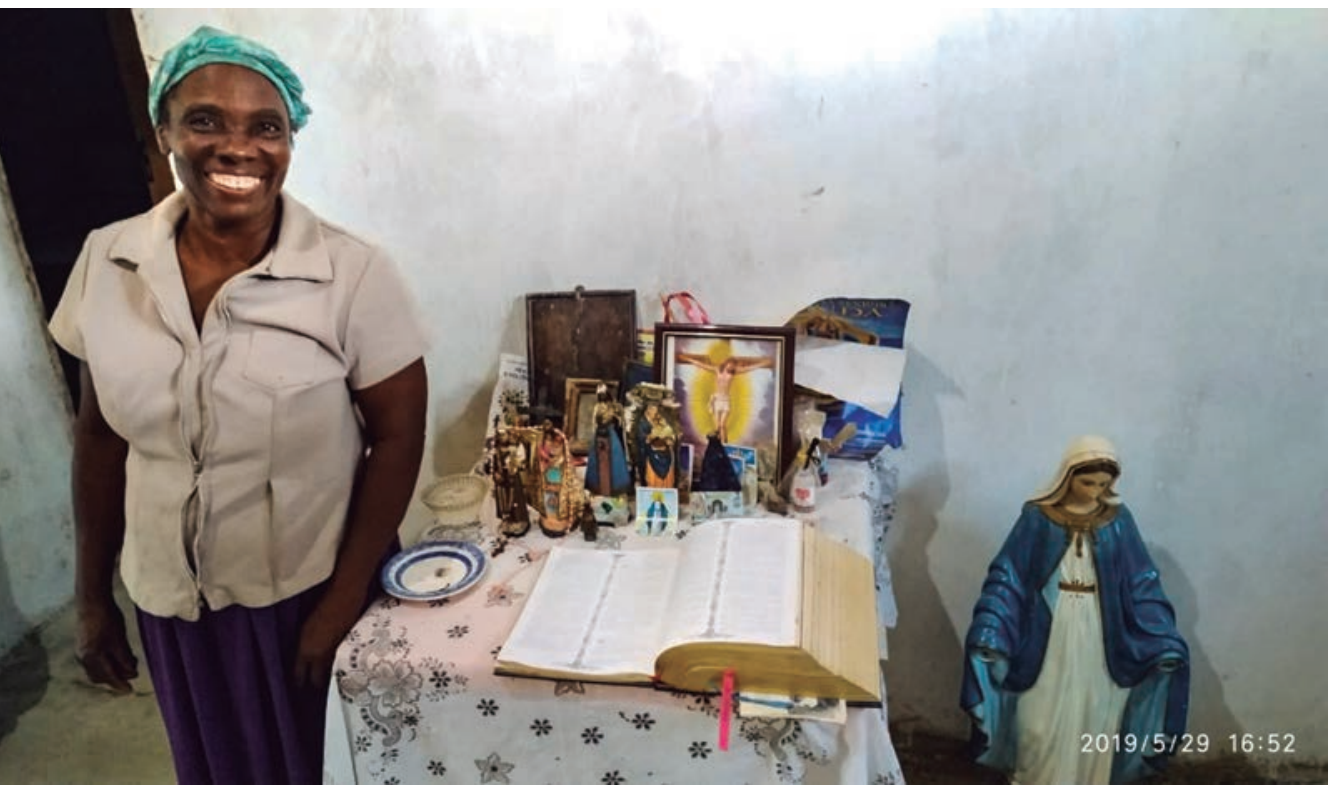

26 - Miúda, a seu

pedido, ao lado do seu oratório (2019). 


\subsection{ZELITA}

De andar e fala ligeiros, Dona Zelita está sempre fazendo algo. Carregando coco no carrinho de mão, rezando na igreja, limpando o terreiro, indo à rua... a vida se passa em movimento. O ritmo, entretanto, não impede que sempre pare e pergunte: está tudo bem, quer um cafezinho?

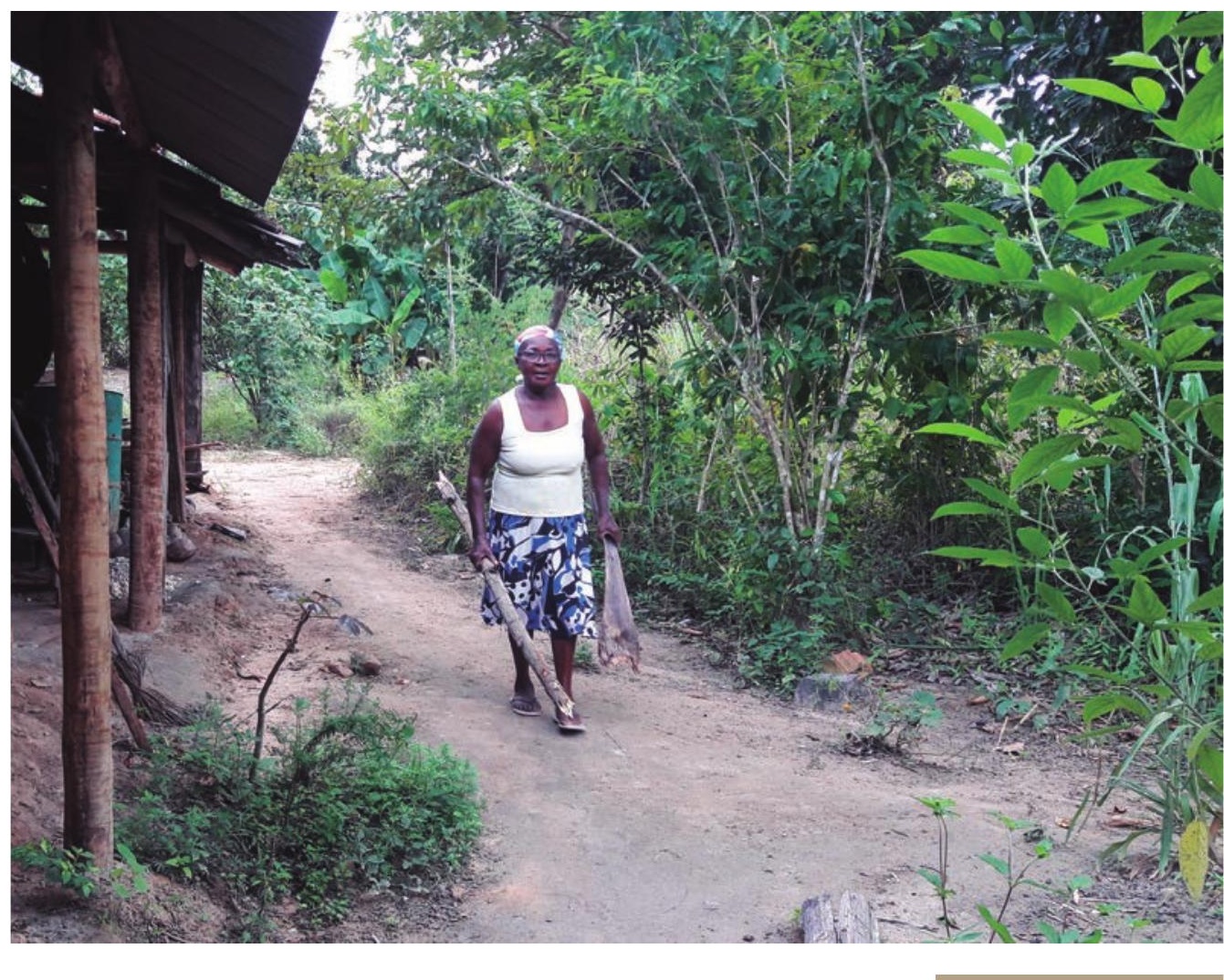

27 - Zelita

(2019) 
Dona de um humor peculiar, ela cuida da lida na roça, sabe fazer dendê e farinha, sabe muito. "Lá ele..." - diz ela, quando parece discordar de alguma coisa. Dona Zelita segue a vida fazendo o que precisa, mas sabe o que quer... vive o presente, mas sente, vigorosamente, a saudade.

"Ah, de vez em quando a saudade é tão grande, tão grande, que dá vontade de juntá meus pano e ir embora", mas o "embora" não é lugar. Ela fala sobre a família que vive longe, fala sobre os que já cumpriram seu tempo e se foram... "E é uma saudade tão grande que dói tudo por dentro".

Para conter a saudade, o melhor é ocupar a mente. Dona Zelita é ligeira e calada, de um abraço forte e contido. A lida lhe é tão natural que chega a duvidar que alguém não saiba fazer farinha... Mesmo desconfiada ela explica: "colhe a mandioca, rala, põe na prensa, passa no motô, penera e leva no fogo a lenha para secá, penera de novo e põe para torrá". A descrição ligeira só não fala sobre a força, asseio e inteligência necessários para fazer o ouro branco em pó.

Na companhia de Miúda, o trabalho começa cedo... As duas se juntam para compartilhar a dança: 

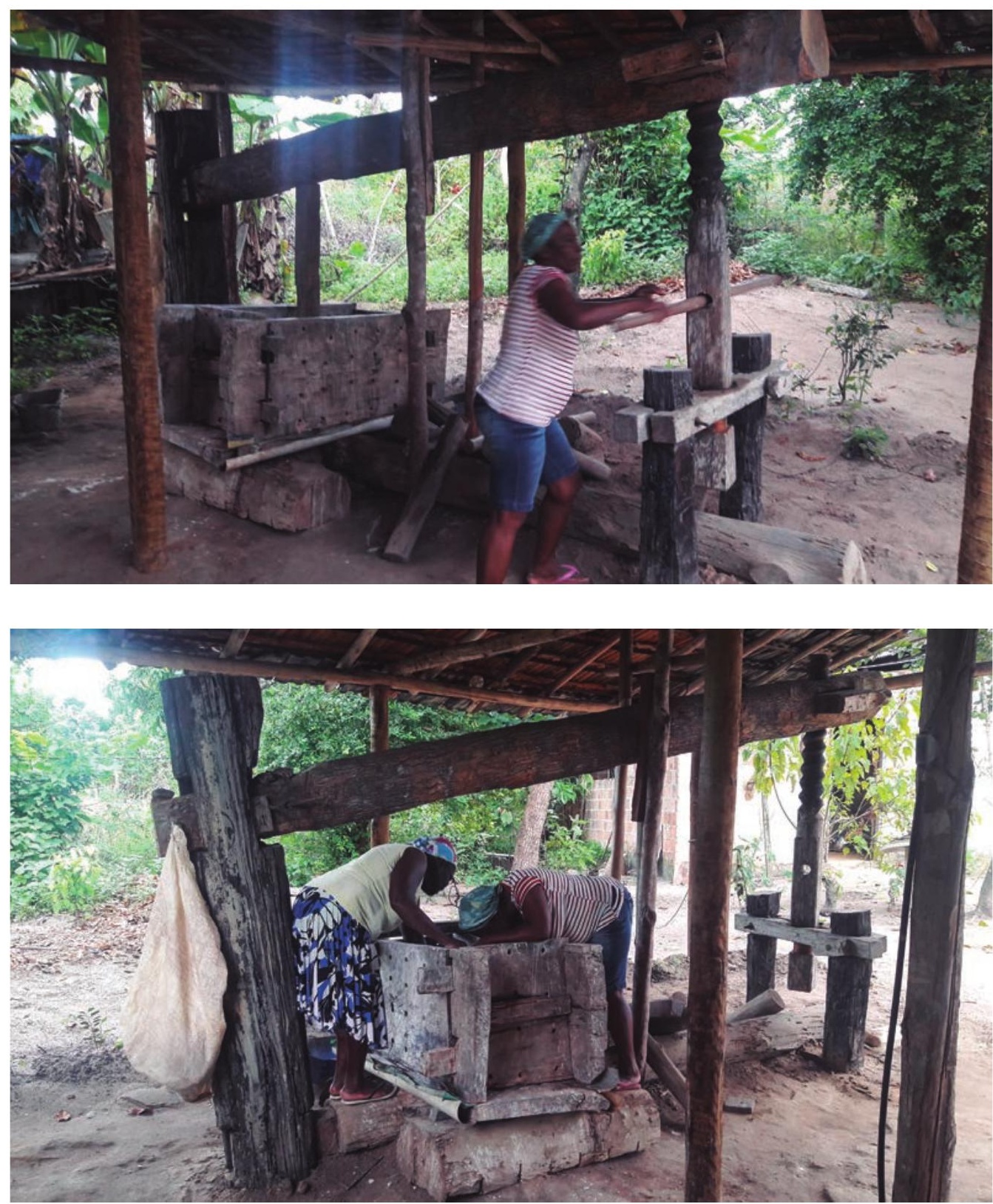

28 a 45 - Fazendo

farinha de Mandioca

(2019). 


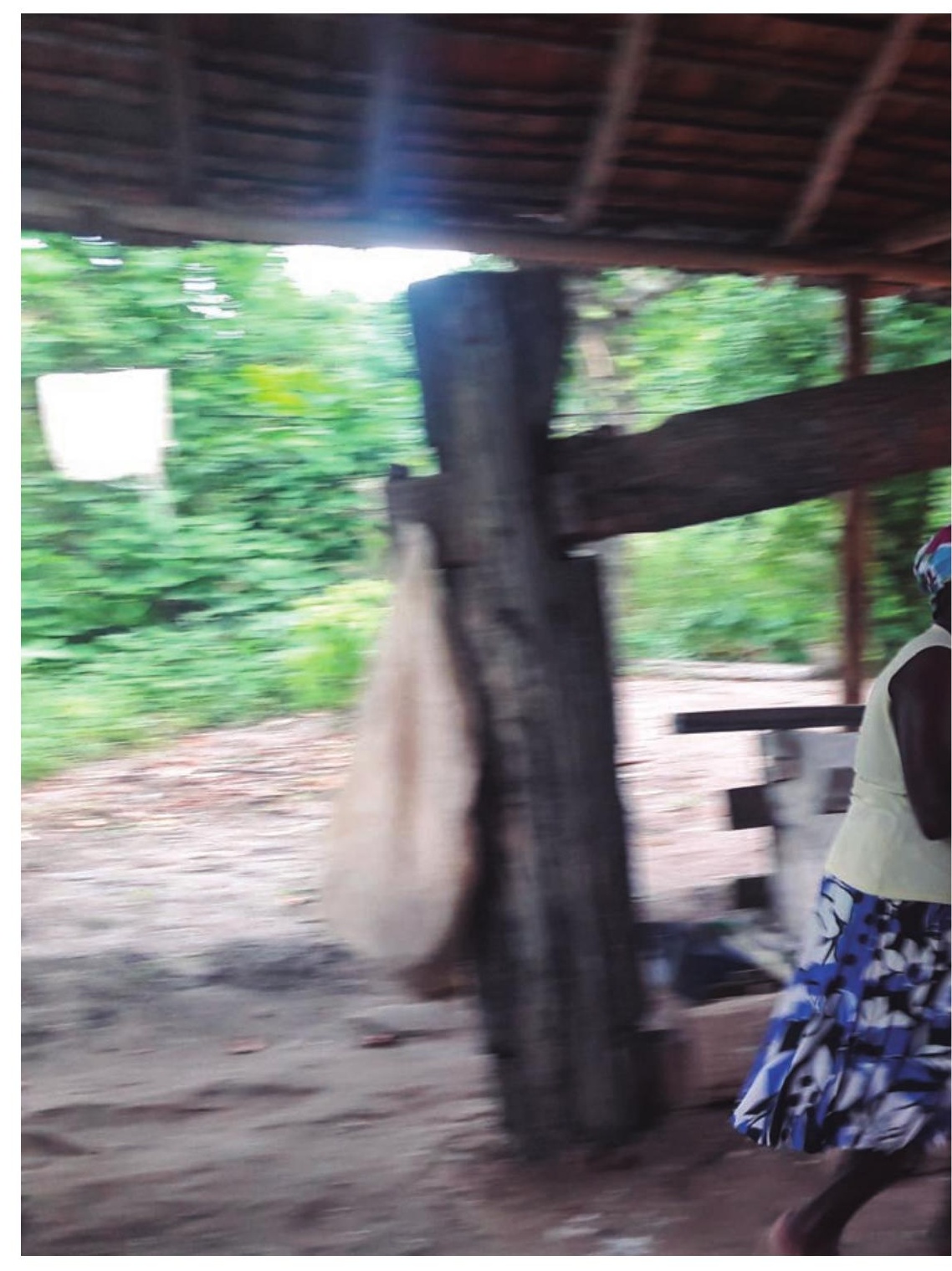

122 


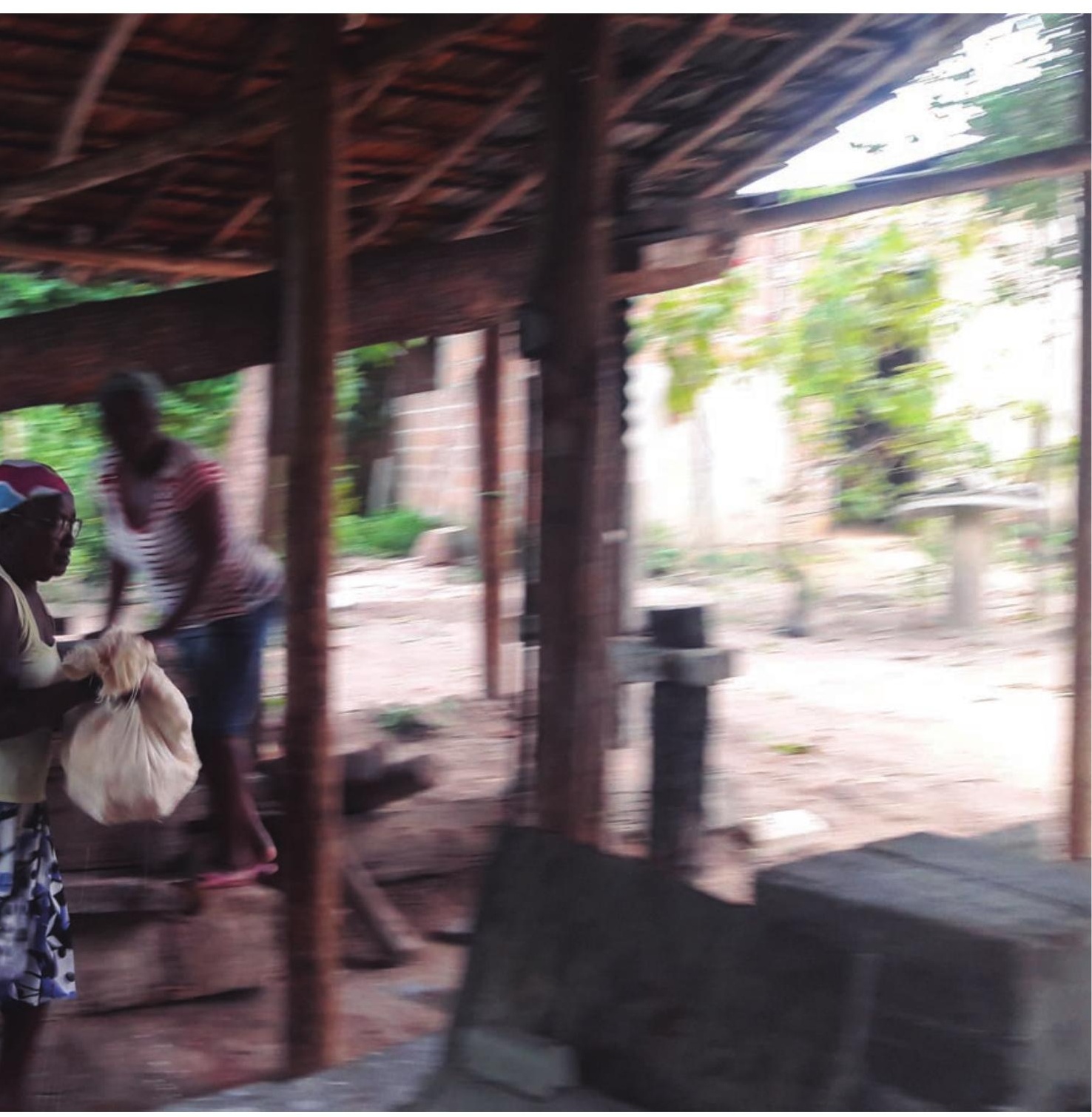



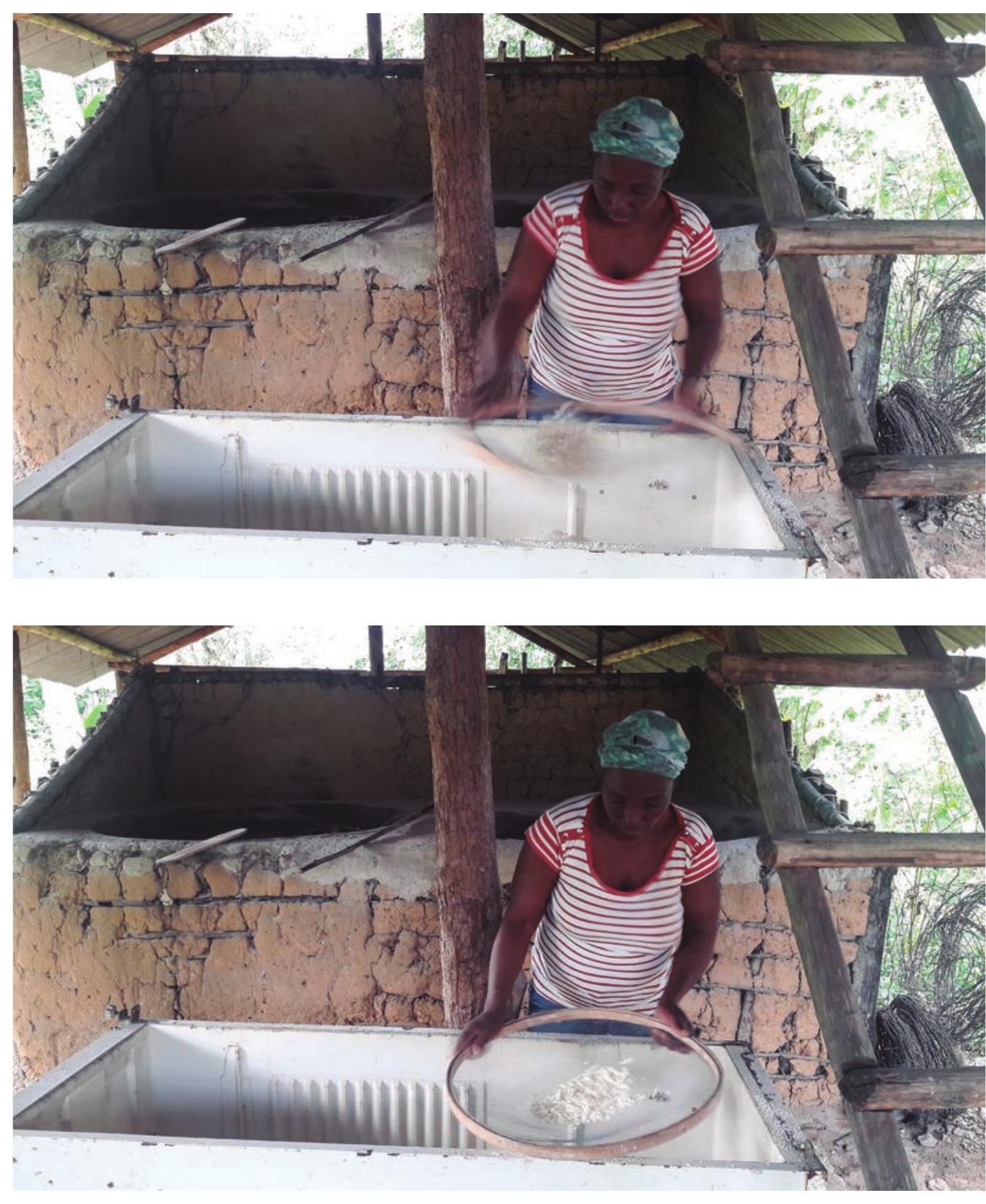

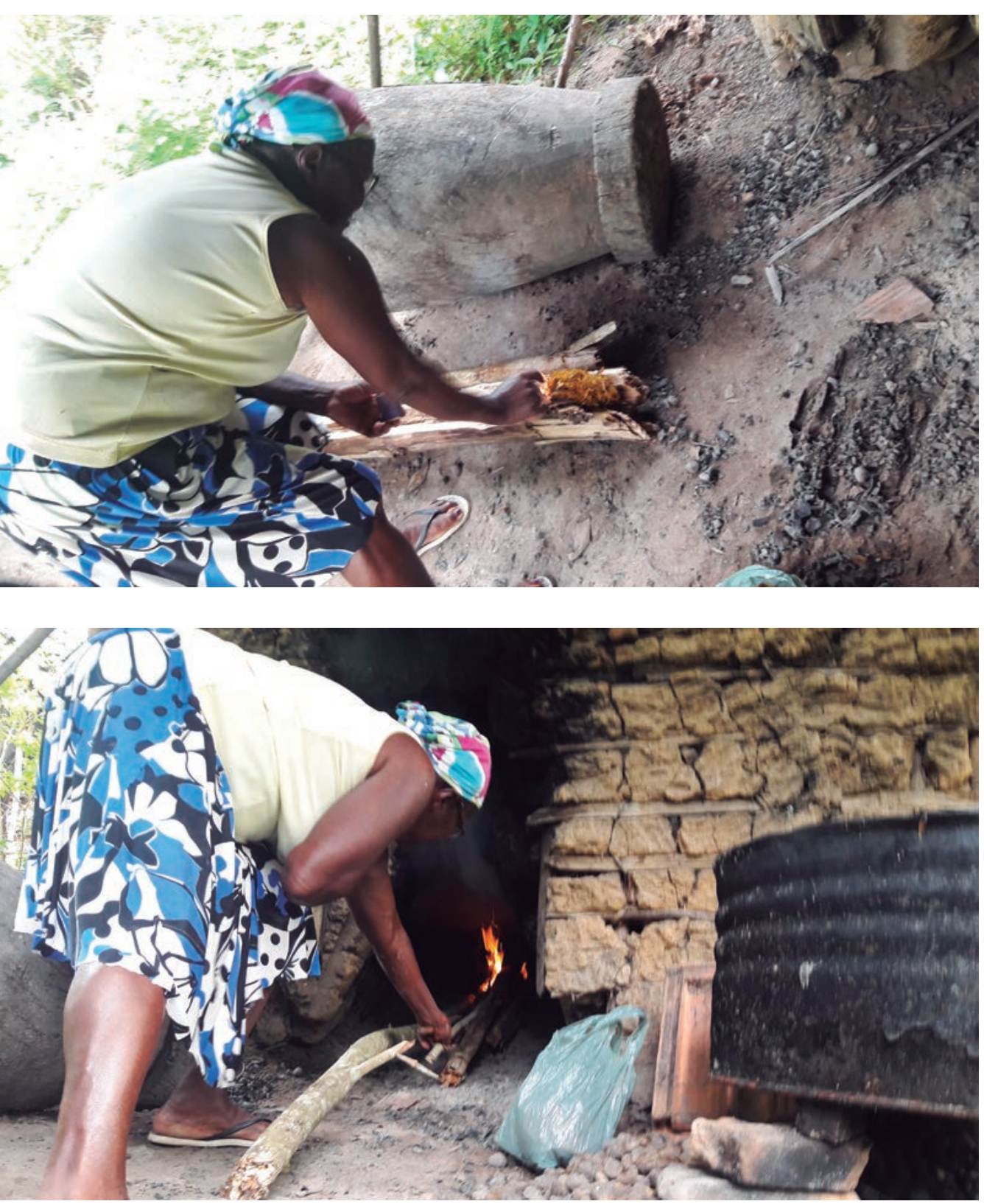

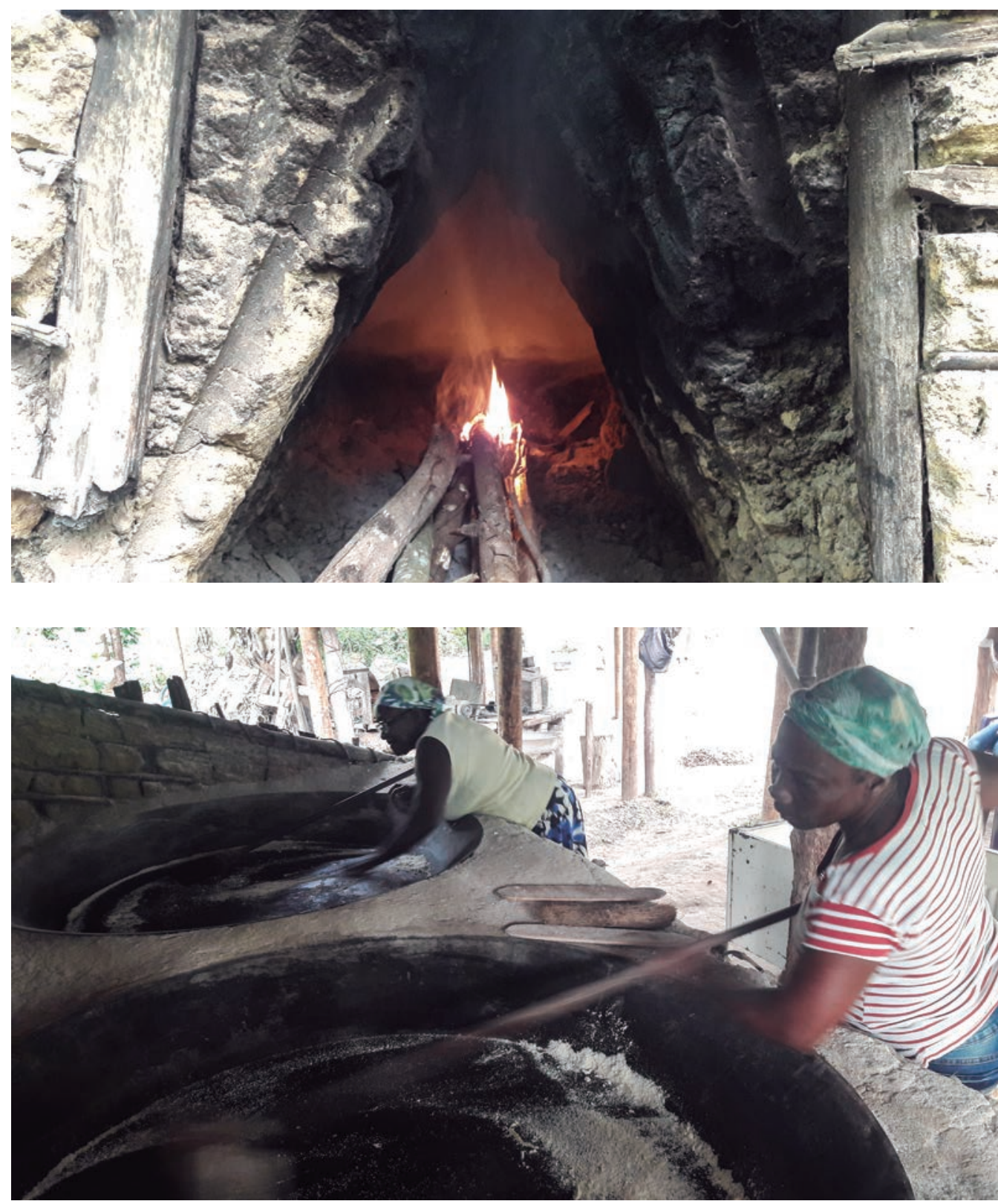

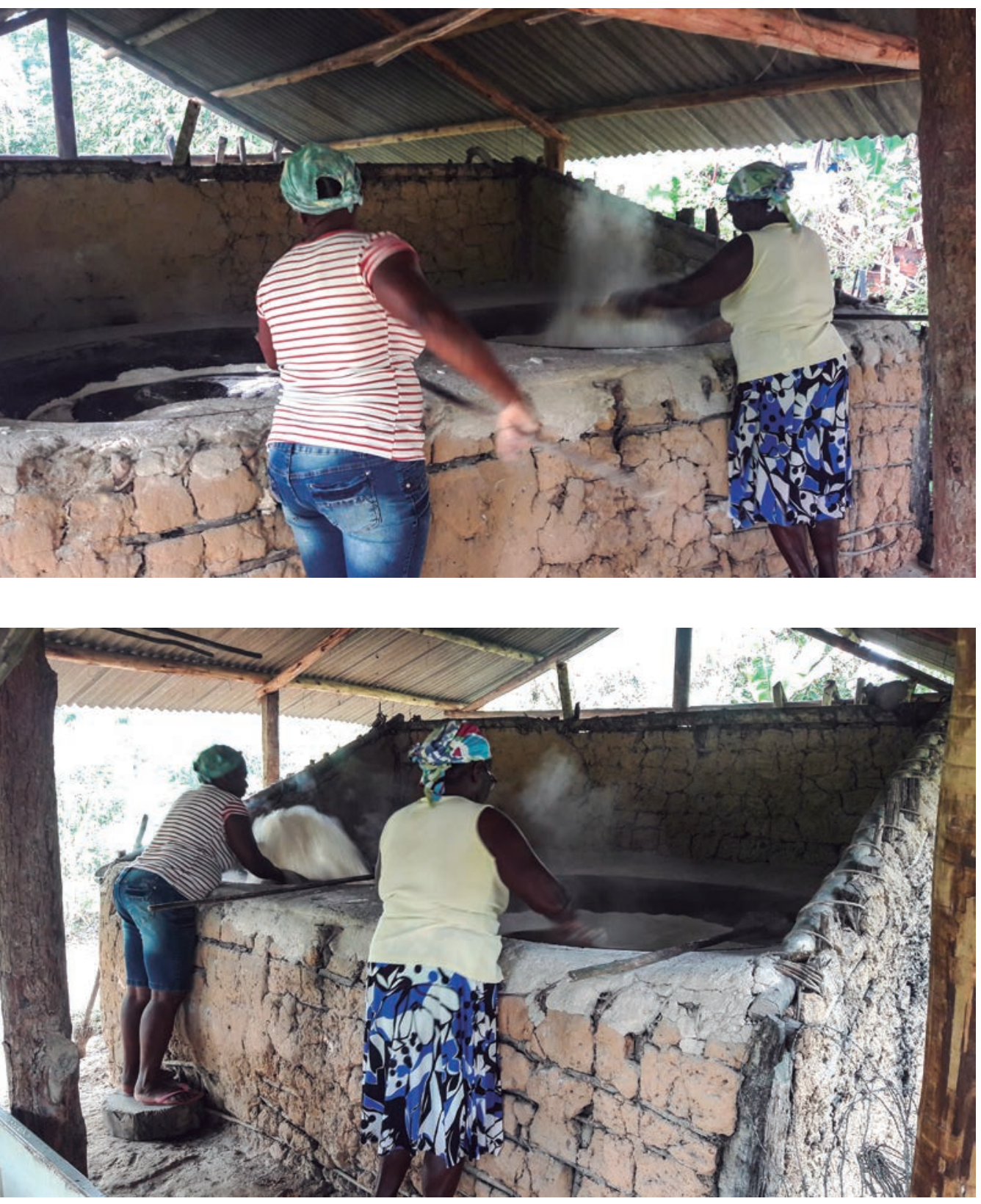

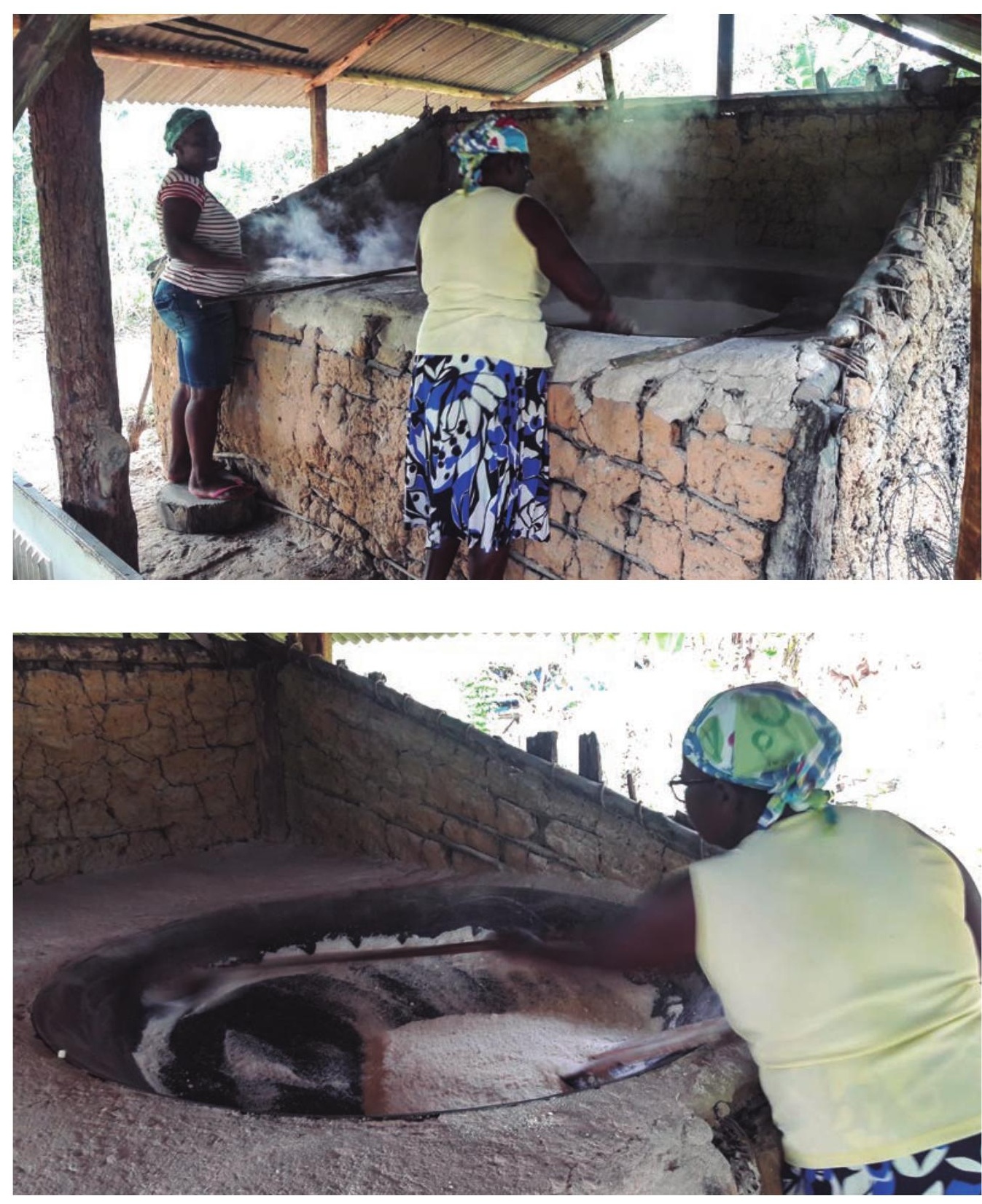


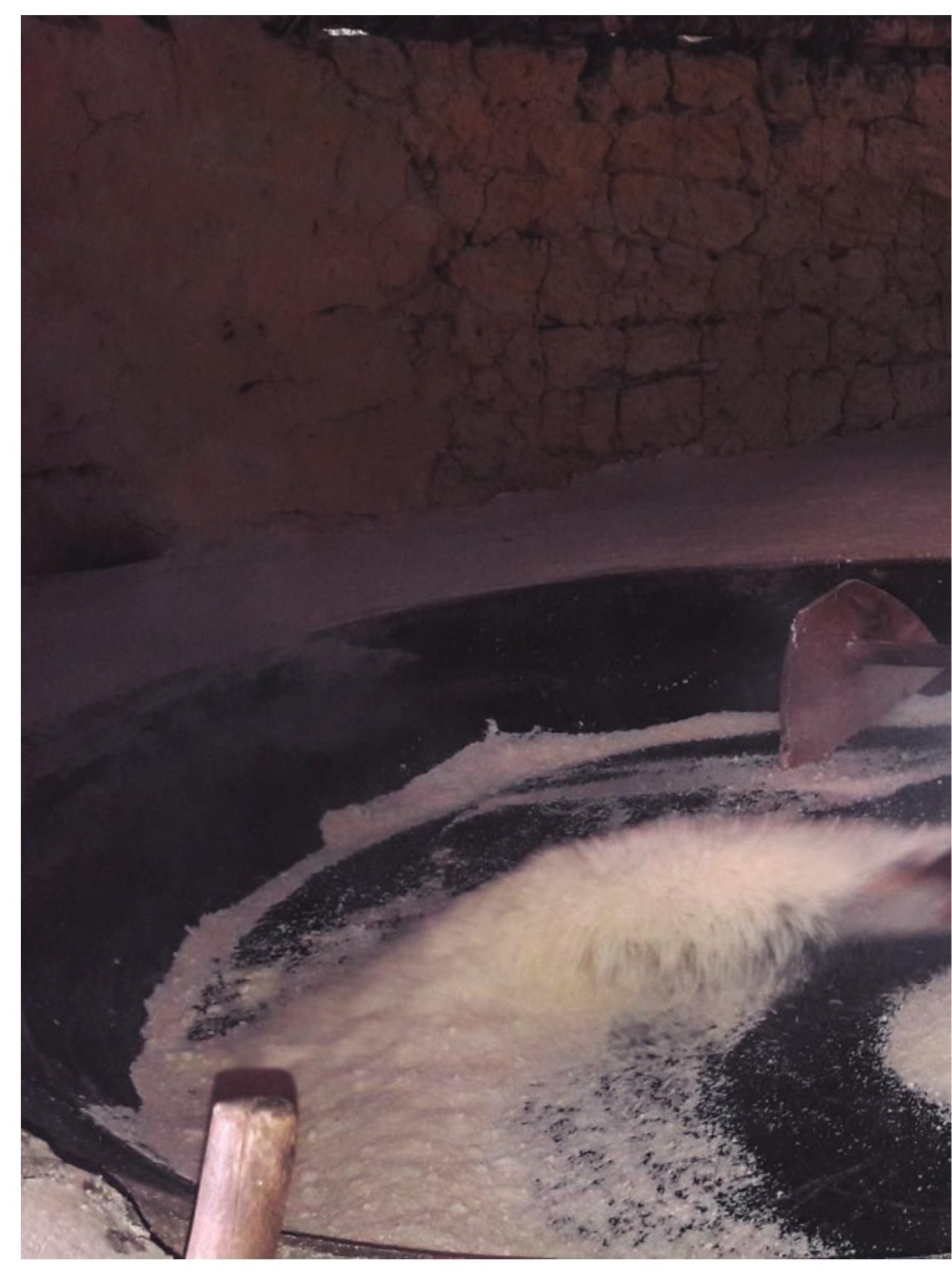




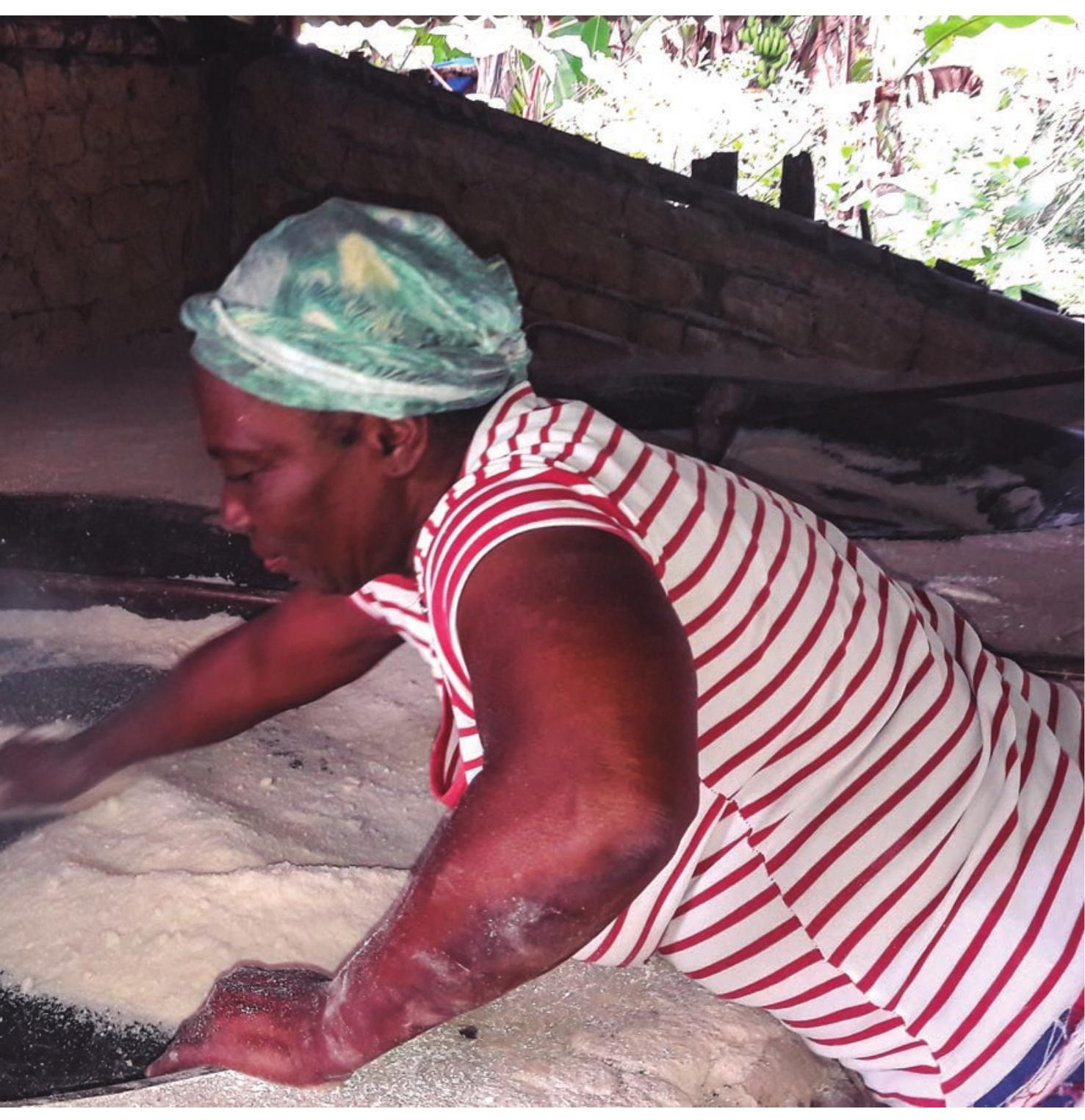




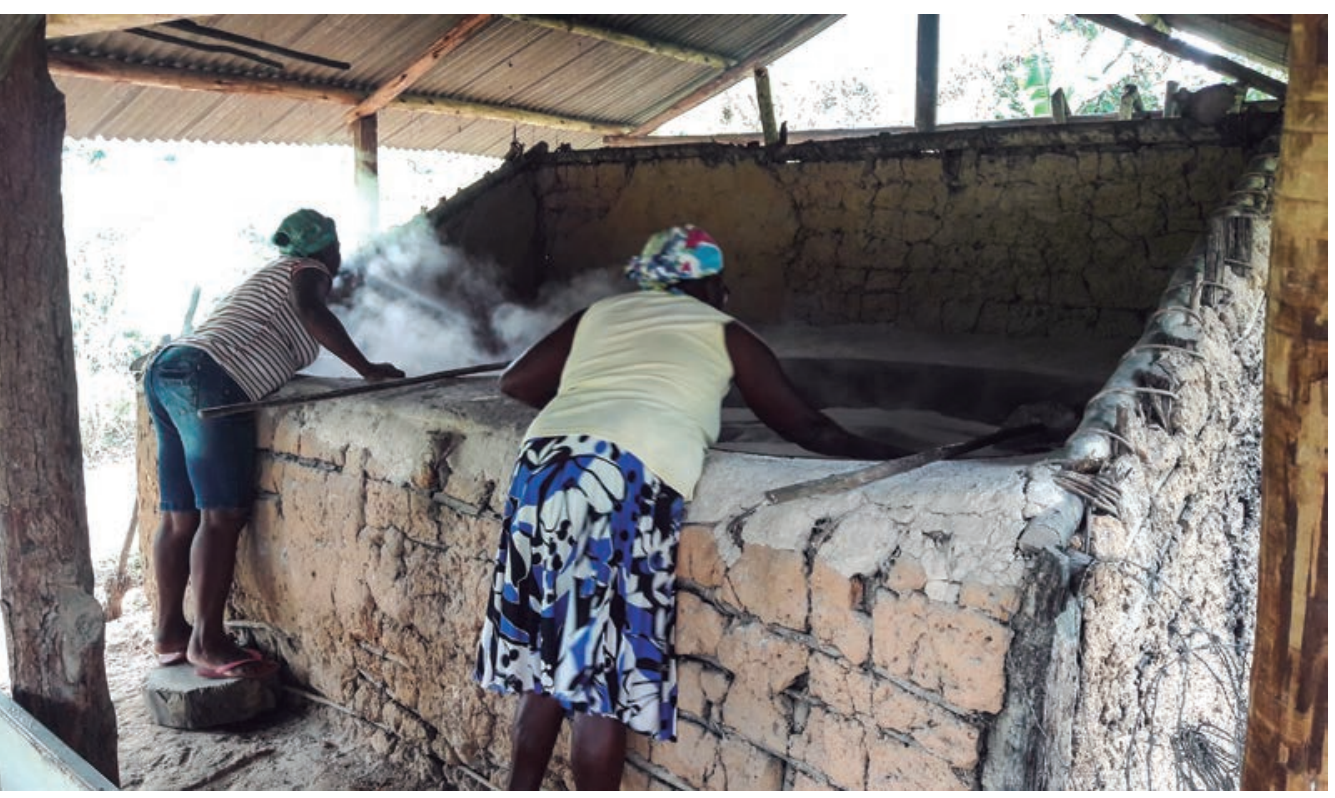




\subsection{DOMINGO ANTÔNIO}

Tudo nasce da terra... Bom, nem tudo. Há coisas que nascem do céu, e, "se vêm do céu, vêm diretamente de Deus". A interpretação do artista sobre a matéria prima da sua obra fala sobre orgulho e humildade.

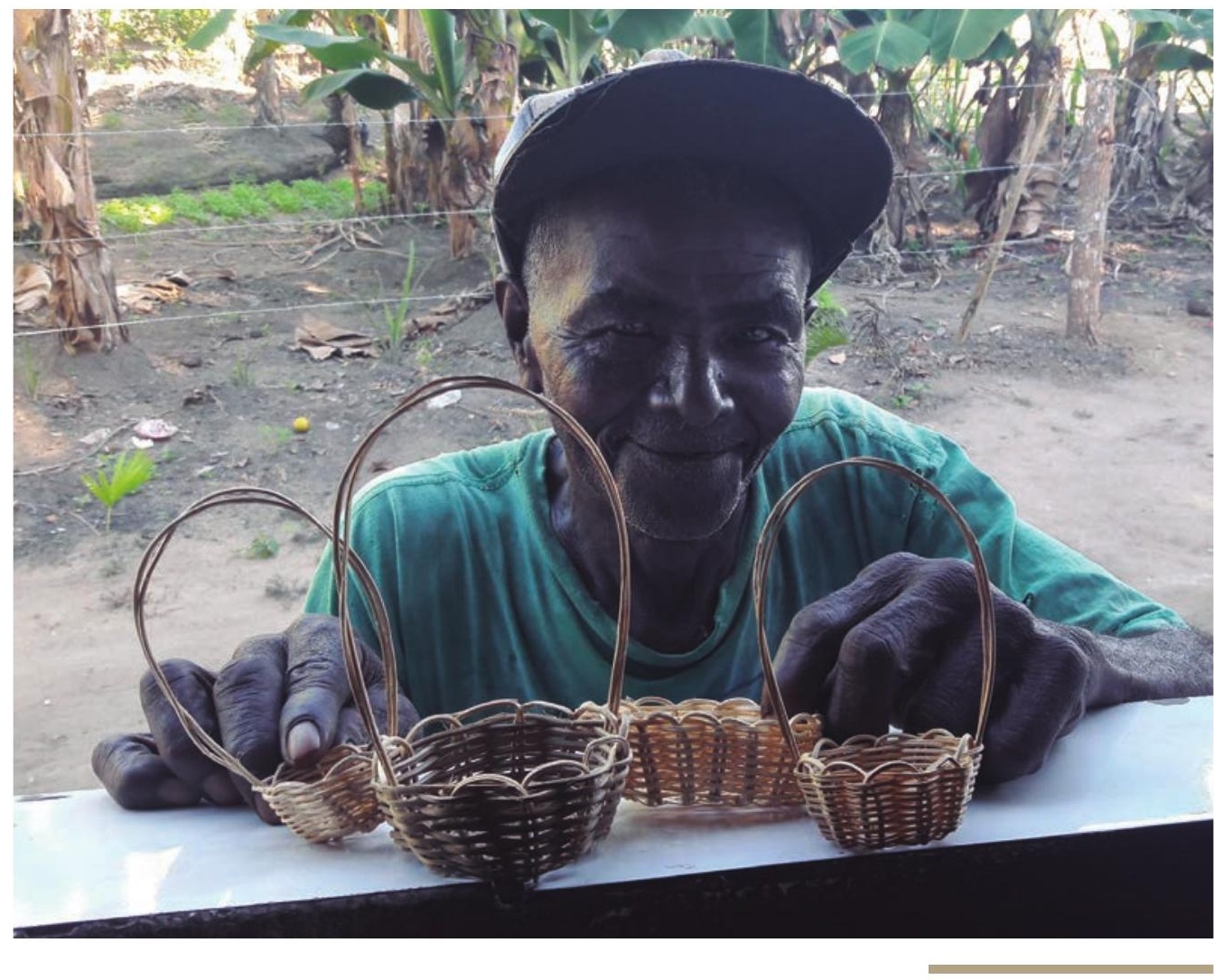

46 - Domingo

Antônio (2019). 
Ao se revelar parte de uma continuidade que vem desde os escravos, ele lamenta não ter guardado nenhum objeto do passado que mostre isso, mas se faz testemunha e prova viva de uma sabedoria e habilidade únicas, que vêm de muito longe... Ele se faz o homem forjado pelos homens e mulheres que vieram antes, muito antes dele.

Da mão à terra, desde o céu, Domingo Antônio tece afetividades com os fios da sua própria história.

"Eu vou lá pegá um pra sinhora ver". Domingo volta com pequenos e delicados cestos, tranças de palha que dão sustentação e forma às estruturas. "Essas são pequenininhas, tem muito maior", as menores demandam mais tempo de fabricação, pois as grandes exigem a mesma habilidade, mas ocupam menos tempo.

O artista faz lembrar que assim também são outras experiências da vida. A tecnologia chega, facilita a conversa com o mundo, mas é a conversa pequena, olho no olho, aquela que exige mais dedicação e entrega, a que revigora a humanidade e sensibilidade entre todos e fortalece a união.

Seu Domingo aprendeu a arte de trançar cipó com o seu pai, Antônio Manoel, que aprendeu com o seu pai (avô de Domingo), Manoel Eugênio. Os filhos de Domingo Antônio também aprenderam com ele a buscar o cipó na mata, cortar em filetes usando o ralo para que as tiras fiquem sempre do mesmo tamanho... e depois armar, a partir do mestre, o objeto que deseja, pequeno ou grande.

O artista faz carumbê ou samburá - para guardar alimentos -, lustres, cestos para guardar roupa, canambote, 
fruteira, cesta redonda com alça, faz panacum - cesto que era usado em cima do lombo de jegue ou burro para carregar mercadorias e/ou pessoas - e faz também vassouras de diferentes tipos. Desenhados a partir do mestre, os objetos ganham vida, e Domingo alerta: "se não tivé o mestre, nunca dá certo".

Esquecendo-se da grandiosidade da sua obra, o artista se maravilha: "Como é que pode né... Todas coisa que nasce é da terra, e esse camarada aqui [o cipó] é de cima". É realmente incrível... moldar o cipó que vem do céu à mão, ser artista e homem do campo, ser Domingo Antônio e ainda em prece admirar a divina grandiosidade da natureza.

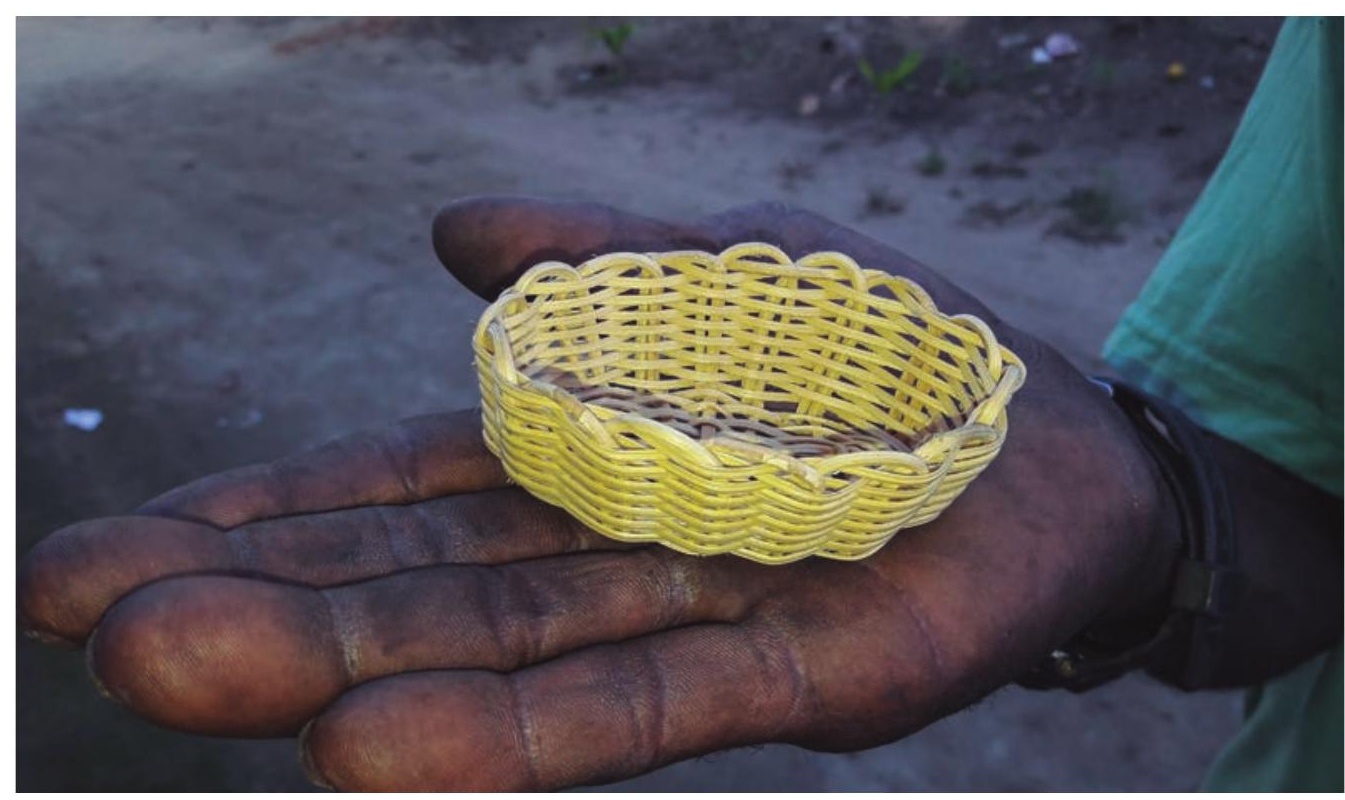




\subsection{MARIA DOS REIS}

Dona Maria apresenta os filhos, genro e os netos... sua história se confunde com a maternidade, de quem a gerou e dos que vieram a partir dela. "Criá filho hoje em dia é uma tarefa difícil, antes também era"... Mas por motivos diferentes.

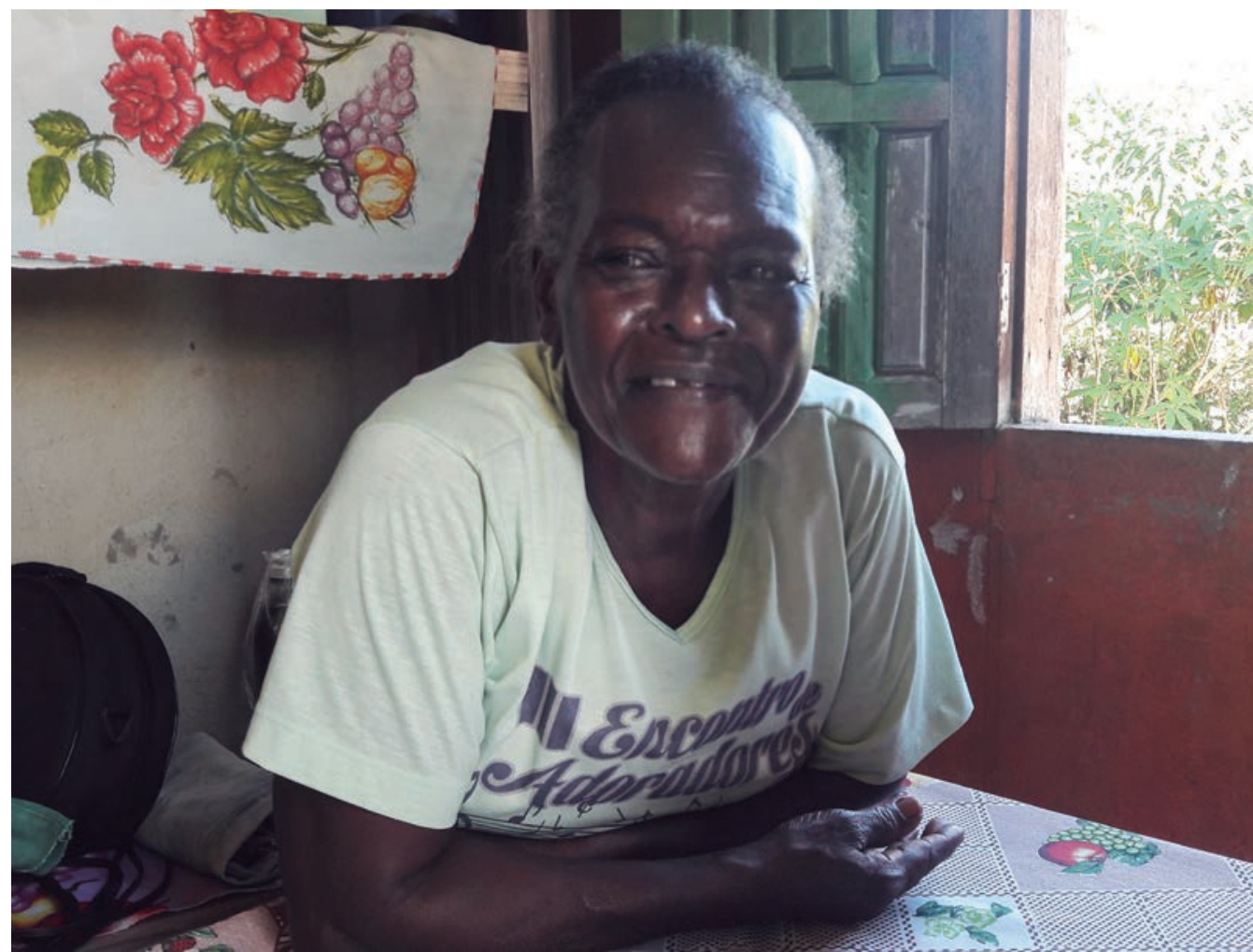


Os modos de viver do passado e do presente têm suas diferenças, mas Dona Maria segue construindo sua família como aprendeu. E segue aprendendo sempre.

O sustento vinha direto da mata, "não tinha emprego, mas ia no rio e pegava peixe desse tamanho, meu pai fazia armadia na mata e pegava caça, trazia para casa, limpava e passava sal, porque não tinha geladeira" - não tinha geladeira, mas também não havia fome.

Dona Maria aprendeu a conservar os alimentos com sal, sol, barro e brasa. A carne era salgada e seca ao sol, o feijão durava de um ano a outro: "misturava no barro, botava para secá e guardava" no carumbê, cesto trançado de cipó.

"Tudo mantinha a gente", o alimento vinha da mata e brotava da terra, que dava de tudo e eram alimentos saudáveis. Hoje os tempos são diferentes, mas Dona Maria dos Reis não fica parada, se não dá para ser como antes, ela vai à escola participar da reunião com pais e mestres, não perde uma reunião da associação, "porque assim a gente aprende e vai sabeno o que tá aconteceno, né". Dona Maria segue a vida como aprendeu a aprender: ouvindo atentamente, e assim ela vai cuidando dos seus. 


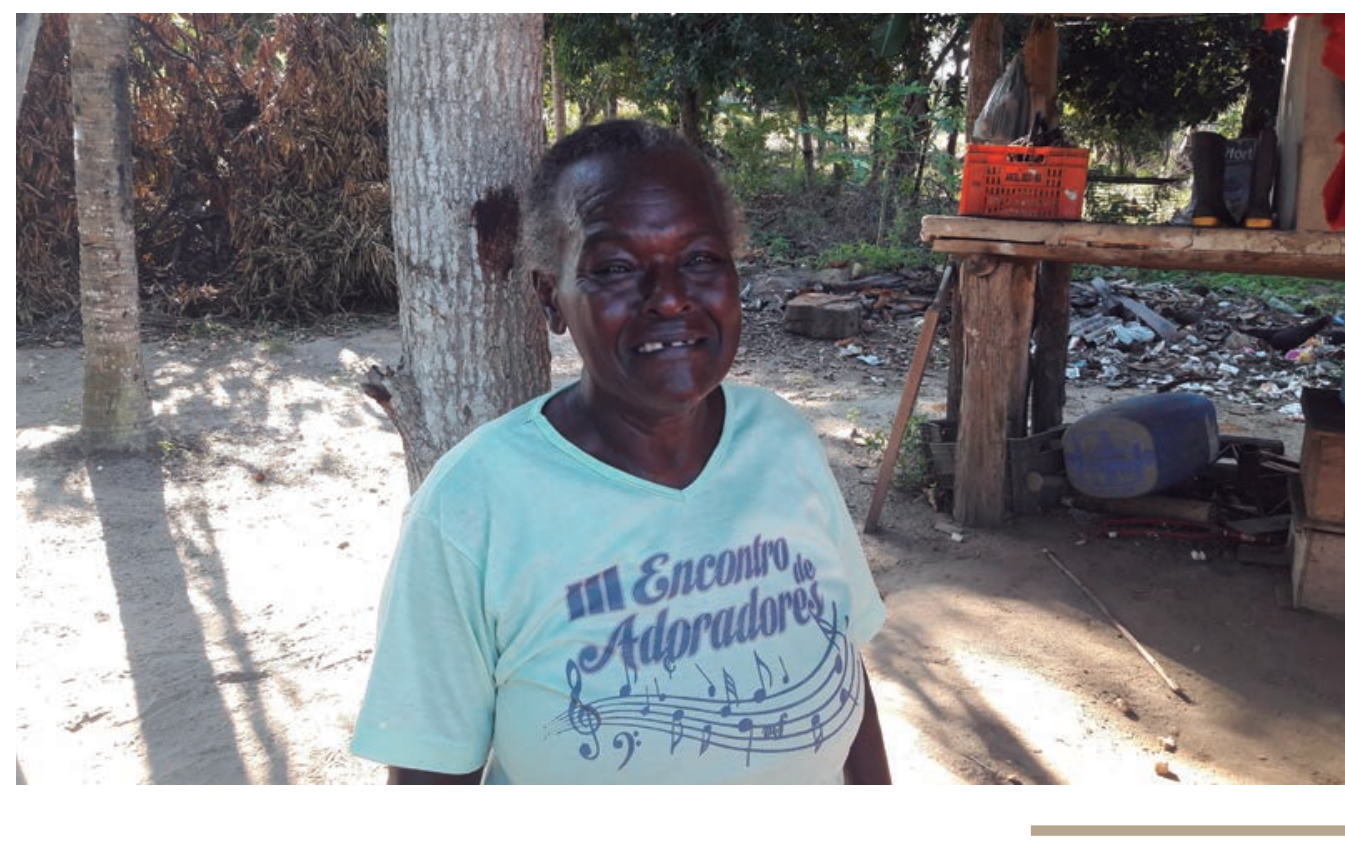

50 e 51 - Maria dos

Reis (2019). 


\subsection{NIDA}

A água para o café esquentava no fogão à lenha, junto a outras panelas. Num fim de tarde em que o sol se punha com preguiça, como quem precisa ir, mas tanto quer permanecer... talvez pela gentileza, afeto e saudosismo que se misturavam no ar. Dona Nida se levanta - apesar das dificuldades que os 82 anos the impõem, mesmo mantendo-Ihe ares de 60.

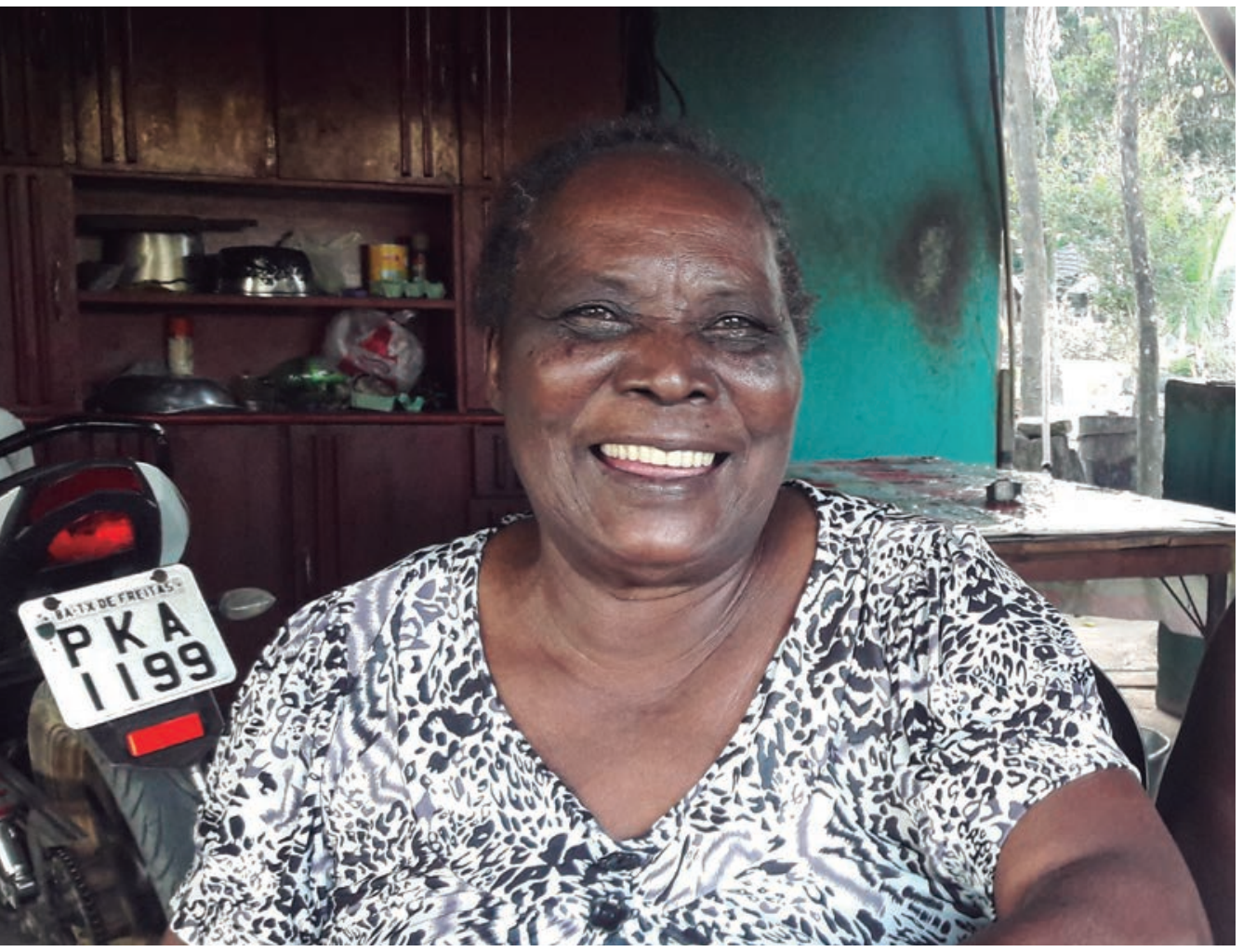

52 - Nida 
No meio da conversa, que se passava numa mesa posta à varanda, foi buscar a água de coco que, noutra oportunidade, Joaquim Serafim, seu marido, havia prometido... a conversa sobre a vida é tecida com pausas e silêncios, mas o sorriso de Dona Nida se abre sempre e ligeiramente, transformando a feição de quem, como ela mesma afirma, "já feiz muito na vida".

Os tempos de hoje podem até não ser bons... Mas Dona Nida garante que já fez "de um tudo, desde menina"... E eis que surge um motivo para sorrir.

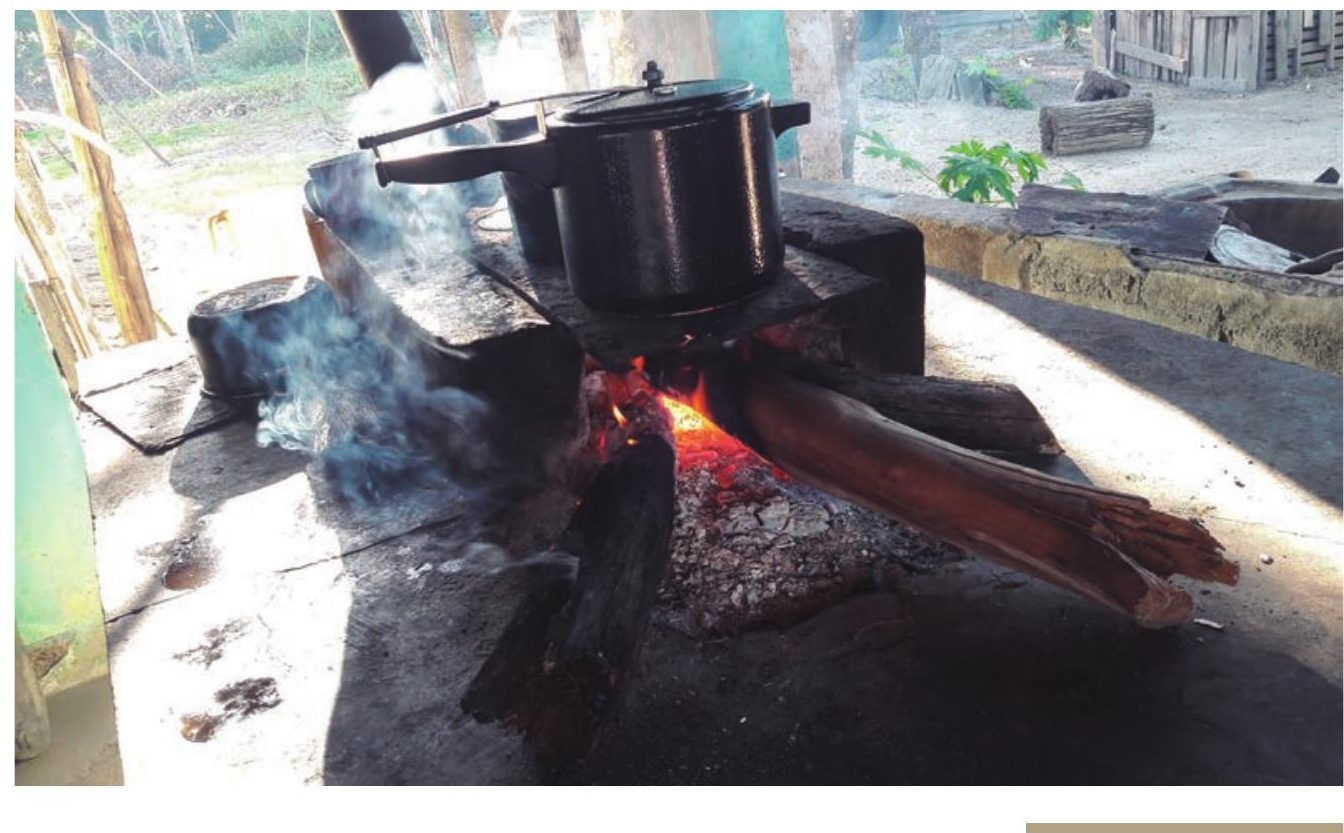

53 - Fogão à Lenha 


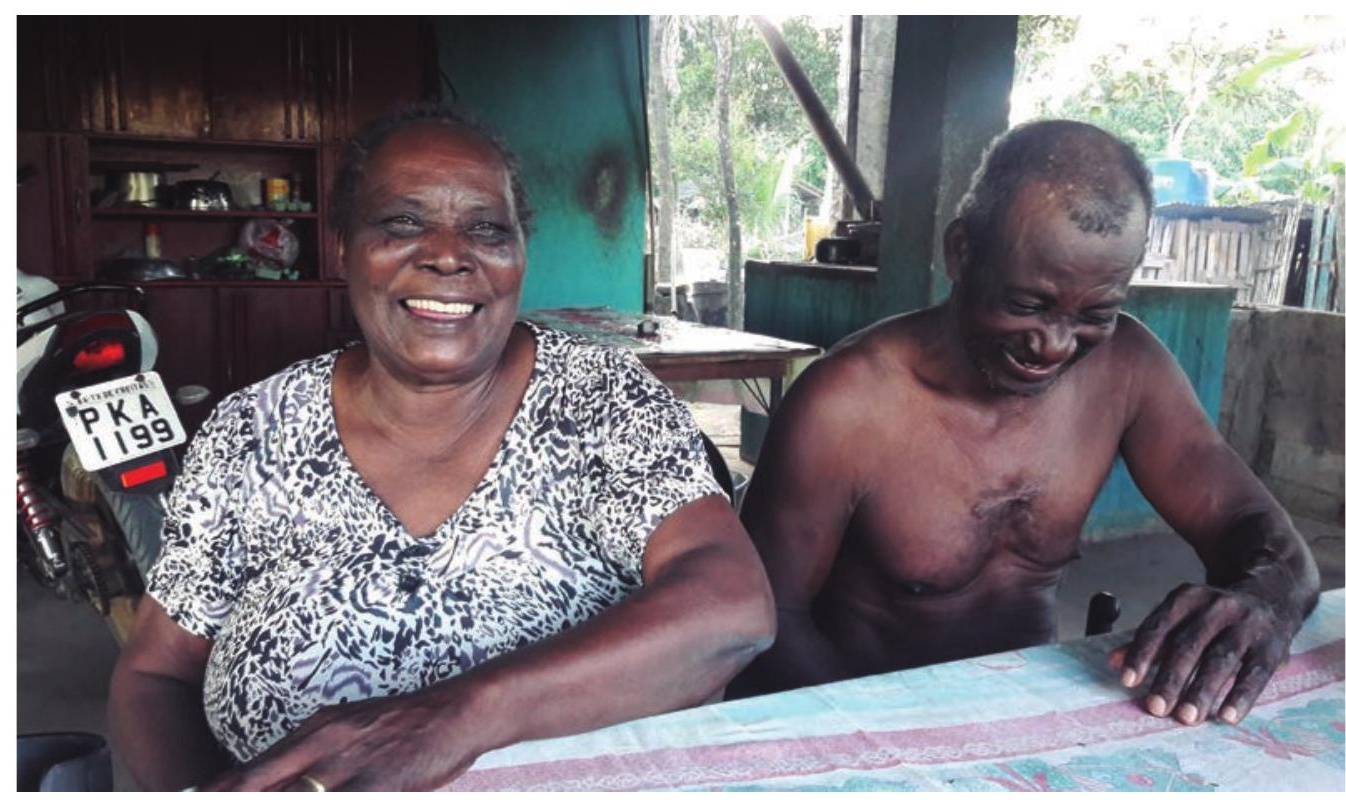

Ela sorri sobre um tempo em que havia muitas festas, 54 e 55 - Nida e Joaquim (2019). festas de santo. Vinha gente de toda a região... Helvécia, Juerana... e se ajuntavam numa casa, rezavam e festejavam - sambavam a liberdade e a fé - por toda a noite, desde o entardecer.

Dona Nida recolhe o sorriso: "A metade já acabô", o tempo passou, os foliões envelheceram... e o tempo deles chegou. A reza pelos mortos ainda continua, "reza no dia que morre, trinta dias reza, seis meis e ano". O sorriso se recolhe, há muito sentimento pelos que se foram e pelo samba que iluminava - que continua a iluminar, em memória, a sua face.

As falas de Dona Nida ecoam em Joaquim, seu marido. Os dois nascidos e criados em Volta Miúda foram se apaixonando com o samba. O encantamento presente no relato desse encontro faz surgir novos sorrisos - nos dois, 
ladeados. É ele que conta: durante o samba, garotas e rapazes trocavam olhares, iam conversando com os olhos, e se aproximando aos pouquinhos. E, de samba em samba, lá se vai meio século juntos.

Foi ele, limpando a roça, à beira da estrada, que convidou para conhecer a sua esposa. Parou a lida, ofereceu um café e uma prosa, apresentou Dona Nida, que fala em saudades que são um presente no presente... que são capazes de fazer brotar e resplandecer, novamente e sempre, um sorriso. São memórias que iluminam. 
豆 



\section{Da voz à letra: oralida- de, ancestralidade e resistência}

O dom da palavra - que é vida - permeia a existência de Domingos Serafim, com humor peculiar, sentado à sombra de um coqueiro em frente a sua casa, em Volta Miúda, ele rememora o passado e reflete: "quem é que não gosta de uma coisa boa?". E ele continua, "Tenho meu respeito com quarquer um, mas também se a gente não fizer graça morre à toa, viu?" (Domingos Serafim, 9 de junho de 2018), contar histórias, relembrar o vivido, recompor imagens, feições, reações, expressar o risível lhe garantem a vida.

Nascido e criado em Volta Miúda, Domingos Serafim conta que "Quando tomei entendimento de gente, ainda topei o cheiro dos escravo, escravo trabalhava debaixo de taca, dona Raíssa" (9 de junho de 2018). O narrador perdeu a visão por volta do início da década de 1990 e talvez por isso construa a cena da violência implementada contra o seu povo a partir da percepção olfativa figurada. Outra explicação possível à sua menção ao "cheiro" é que advenha da sua experiência e ancestralidade, haja vista que esse sentido 
aparece como um descritor muito comentado no século XIX, embora associado à discriminação e repulsa da participação dos negros nos ambientes sociais. Cláudio de Paula Honorato, em dissertação acerca do "Valongo: o mercado de escravos do Rio de Janeiro, 1758-1831", cita:

Os viajantes que por aqui passaram deixaram registrados diversos comentários sobre a exuberante beleza natural a grande luminosidade de cores e tons, mas reclamavam do excessivo calor, dos cheiros desagradáveis e mostravam-se amedrontados pela enorme quantidade de negros nas ruas. A mesma cidade que atraía, causava medo e insegurança. Pairava sobre essa elite o medo, andavam receosos pelos becos e vielas em geral estreitos e irregulares, sujos, mal cheirosos e sombrios onde se amontoavam um grande número de escravos, mendigos e desocupados, excluídos da sociedade, destituídos de quaisquer direitos, mas sempre prontos a mostrar sua presença e suscitar o imaginário de uma elite que já na época temia a africanização do Brasil. (HONORATO, 2008, p. 45-46, grifos meus).

As falas de Seu Domingos carregam forte ligação com a experiência vivida com os seus ascendentes, as memórias denunciam e/ou expressam o processo de violência a que foram submetidos os ancestrais: "Vó Júlia falava que com o escravo era assim: botava, futucava formiga preta e botava criança lá, pra formiga preta mordê... não podia chorar, é verdade, escravo disse que foi duro, e hoje tem, tem uma catingazinha, um cheirozinho de escravo". As histórias contadas pela avó Júlia são compartilhadas em paralelo à afirmação de que Volta Miúda é uma comunidade feliz, informando o cheiro como reflexo do estado de continuidade em que resiste a negritude quilombola de Volta Miúda. 
Ao se debruçar sobre a figura do narrador - este sujeito que conta, relata, apreende experiências próprias e de outrem e as repassa -, Walter Benjamin (1994, p. 221) chega à conclusão de que "Seu dom é poder contar sua vida; sua dignidade é contá-la inteira”. A inteireza aduzida por Benjamin suscita dúvidas, possibilita a amplitude interpretativa. Para ele, narrar não se trata da concatenação de fatos, mas da exposição de experiências em intercâmbio. Com deferência, o autor afirma que, com capacidade cada vez mais rara, "o narrador figura entre os mestres e os sábios. Ele sabe dar conselhos: não para alguns casos, como o provérbio, mas para muitos casos, como o sábio. Pois pode recorrer ao acervo de toda uma vida" (BENJAMIN, 1994, p. 221). A inteireza referida por Benjamin parece menos relacionada à exigência de muitas experiências do que à relação holisticamente implicada que o narrador estabelece com as vivências em intercâmbio. Assim como aponta Hampâté Bâ (2010, p. 199) sobre os griots genealogistas, que se constituem autoridades por preservar a história e, com ela, a inteireza que conforma o mundo e a alma africana.

Narrar é, pois, uma forma comunicacional descompromissada com o imediatismo, do qual a informação é vassala. Opõe-se, portanto, à volatilidade incutida pelas relações sociais que vão se consolidando com a burguesia e no contexto do regime capitalista. O agora, a urgente entrega para compreensão, ainda que superficial, da informação, é rejeitada pela arte da narrativa, que se vincula ao sentir, à senciência ${ }^{10}$ para admitir que a escuta digna se concebe com a abertura do ouvinte à integração do narrado com a sua própria experiência. Como ensinou o filósofo, "Quanto mais o ouvinte se esquece de si mesmo, mais profundamente se 
grava nele o que é ouvido" (BENJAMIN, 1994, p. 205), trata-se, portanto, de encontro, da refutação da individualidade e competitividade incentivadas pelo sistema-mundo moderno-capitalista.

A oralidade, nas tradições africanas, além de valor moral possui caráter sagrado, é definida por ele como o conhecimento total: "Fundada na iniciação e na experiência, a tradição oral conduz o homem à sua totalidade e, em virtude disso, pode-se dizer que contribui para criar um tipo de homem particular, para esculpir a alma africana" (HAMPÂTÉ BÂ. 2010, p. 170). No mesmo sentido, Zumthor (2010, p. 15), ao referir-se às tradições africanas, atribui capacidade transformadora e curativa à oralidade:

Ora, a voz é querer dizer e vontade de existência, lugar de uma ausência que, nela, se transforma em presença; ela modula os influxos cósmicos que nos atravessam e capta seus sinais: ressonância infinita que faz cantar toda matéria (ZUMTHOR, 2010, p. 9).

Perceber a dominação fundada na hierarquização sociocultural e a repulsa do sistema-mundo colonial capitalista a individualidades que não se adequam ao sentido do lucro e da produtividade é admitir que estejam sujeitas a uma destruição sistemática desde o nascimento (BOSI, 1994, p. 80). A decadência da arte de contar histórias e trocar experiências alija da integração social grupos de tradição oral - tais como povos indígenas, africanos e afrodescendentes - e, em outro paralelo, os anciãos. Para estes, há ruptura da comunicação com o desestímulo ao diálogo que, em via dupla, afeta narrador e ouvinte. Após uma vida de aprendizagens 
e experiências, o sujeito envelhecido, um narrador por excelência ou por força das circunstâncias da senilidade, perde a capacidade e/ou o meio de transmiti-las, o sentimento de continuidade é afetado pela sociedade industrial, que the retira, então, a dignidade.

"Que é, pois, ser velho na sociedade capitalista?", questiona Marilena Chauí, ao prefaciar Ecléa Bosi, referindo-se ao velho urbano, ignorando o recorte racial, "É sobreviver. Sem projeto, impedido de lembrar e de ensinar, sofrendo as adversidades de um corpo que se desagrega à medida que a memória vai-se tornando cada vez mais viva, a velhice, que não existe para si mas somente para o outro [opressor]" (CHAUÍ, 1994, p. 18-19). Falar sobre as/os anciãs/os de Volta Miúda é adentrar ao espectro em que a velhice no contexto capitalista se intersecta com a negritude, gênero e a ruralidade. Compreendendo-se que o desfazimento da identidade favorece o controle, visto que "um homem não sabe o que ele é se não for capaz de sair das determinações atuais", o movimento de retorno à oralidade - "atmosfera sagrada" (BOSI, 1994, p. 91) - é, nesta perspectiva, hábil à devolução da vida. "Para que nenhuma forma de humanidade seja excluída da humanidade é que as minorias têm lutado, que os grupos discriminados têm reagido" (BOSI, 1994, p. 81), e é por meio da interculturalidade ${ }^{11}$ premente na oralidade - esta região fronteiriça que integra narrador e ouvinte -, sob uma perspectiva crítica, que se pode contribuir à deflagração das estruturas que fomentam a excludente estrutura social.

Inobstante as influências do materialismo histórico ${ }^{12}$, o que se quer é refletir quanto ao desestímulo do exercício
11. A interculturalidade, ao contrário do multiculturalismo, pressupõe o "reconhecimento recíproco e disponibilidade para enriquecimento mútuo entre várias culturas que partilham um dado espaço cultural" (SANTOS, 2009, p. 9).

12. Marco teórico que atribui às mudanças tecnológicas e ao modo de produção fatores principais de mudança social, política e jurídica. Conforme Karl Marx (1859, p. 338), “O sistema de produção da vida material condiciona todo o processo da vida social, política e espiritual". 
dialógico, o qual, fomentado pelas mutações comunicacionais com o advento do capitalismo e globalização, também Ihes serve de motor. Há aqui uma retroalimentação sistemática: a tradição oral é olvidada em função de formas comunicacionais modernas, especialmente pela imposição da linguagem escrita, que contribui ao processo de silenciamento e dominação das nações, povos e etnias de tradição oral, que são subalternizados. Contextualizar este processo evoca, conforme Rita Segato (2017, p. 49), a discussão sobre o racismo estrutural, fatores, valores e práticas que contribuem para o estabelecimento de pessoas não brancas em posições de menor prestígio e autoridade. Racismo que torna vítimas "aquellos que conjugan una diferencia racial, un signo fenotípico, con un patrimonio cultural idiosincrático. Se trata, entonces, de un grupo étnico-racial discriminado" (SEGATO, 2017, p. 45), a exemplo das populações quilombolas no Brasil.

É importante elucidar que a utilização de códigos escritos para a comunicação não é uma habilidade exclusiva das nações europeias, visto que sociedades latino-americanas - a exemplo dos incas, maias e astecas - muito antes das invasões colonialistas, eram adeptas da linguagem escrita. O que as diferenciam, entretanto, é a relação travada com e a partir desta, em parte pelo protagonismo atribuído à letra em detrimento da oralidade e o fato das nações europeias imporem a sua experiência comunicacional como paradigma de legitimação de toda organização social e epistêmica. Ao questionar a hierarquia implementada pelos colonizadores, Diana Taylor (2013, p. 136-137) problematiza que "se a memória coletiva se apoia em estruturas sociais para possibilitar a transmissão, as práticas comportamentais que definem 
a etnicidade participam dessa transmissão". Portanto, a negação à estrutura elementar mnemônica dos povos de tradição eminentemente oral culmina no aprisionamento dos próprios corpos.

Com certo grau de ironia, Hampâté Bâ (2010, p. 168) pergunta: "Não faz a oralidade nascer a escrita, tanto no decorrer dos séculos como no próprio indivíduo?", decerto que, se se considerasse legítima a hierarquização sociocultural, há uma inversão inevitável de posições. O xamã Yanomami Davi Kopenawa, em livro com relatos seus reunidos pelo etnólogo Bruce Albert, também rechaça a relação de inferioridade atribuída à oralidade e tece crítica aos "brancos", aduzindo uma limitação não apenas cognitiva como metafísica à cultura moderna/eurocentrada:

Os brancos se dizem inteligentes. Não o somos menos. Nossos pensamentos se expandem em todas as direções e nossas palavras são antigas e muitas. Elas vêm de nossos antepassados. Porém, não precisamos, como os brancos, de peles de imagem para impedi-las de fugir da nossa mente. Não temos de desenhá-las, como eles fazem com as suas. Nem por isso elas irão desaparecer, pois ficam gravadas dentro de nós. Por isso nossa memória é longa e forte. [...]

Omama não nos deu nenhum livro mostrando os desenhos das palavras de Teosi, como os dos brancos. Fixou suas palavras dentro de nós. Mas, para que os brancos as possam escutar, precisam que sejam desenhadas como as suas. Se não for assim, seu pensamento permanece oco. Quando essas antigas palavras apenas saem de nossas bocas, eles não as entendem direito e as esquecem logo. (KOPENAWA; ALBERT, 2015, p. 75-77). 
Para o xamã, contar histórias, um aprendizado ancestral, perfaz um instrumento para elucidação das ambiguidades do presente, é exercício que emana dos próprios deuses, ou melhor, espíritos, que sustentam o céu e que explicaram, desde os antepassados, que o vilipêndio à natureza - se os brancos insistirem em destruí-la - secará a terra, rachará as pedras no calor, murchará as árvores, fará com que os rios desapareçam debaixo da terra e o chão se desfará. Silenciosa e ressecada a terra, os xamãs morrerão e, não mais havendo quem sustente o céu, ele desabará (KOPENAWA; ALBERT, 2015, p. 492-494).

Ritos e fé, comportamento e organização coletiva, estão interligados. Kopenawa, ao falar sobre o seu povo, conta sobre uma vivência implicada à sustentação do próprio mundo, relação de causalidade que se distancia da cultura de satisfação individualista presente na modernidade e que, por muito tempo, propagou negros e índios como povos aculturados, destituídos de civilidade e humanidade. Diana Taylor (2013, p. 134) enfatiza: "As estruturas mentais - que incluem imagens, histórias e comportamentos - constituem um arquivo e um repertório específicos. A raça é construída socialmente", a desconstrução do lugar cênico subalterno atribuído aos povos colonizados e escravizados, negros e indígenas perpassam, então, pela refutação da linguagem escrita como paradigma de validação da experiência, da ciência e da fé.

A discussão acerca da narrativa, da linguagem enquanto performance que reflete e é a própria identidade, composta por um conjunto mnemônico singular, conduz à memória (e a história) enquanto direito elementar à 
consecução da dignidade humana (BRASIL, 1988, art. 5 , $\$ 2^{\circ}$, p. 215-216), pois, manipulando-se a linguagem, perde o indivíduo o vínculo contínuo a partir do qual transcende a sua cultura e origem. Sem a efetivação deste direito à memória, condena-se os descendentes diretos e indiretos dos povos que não compartilham do corpus cultural eurocentrado ao limbo identitário.

A memória é um objeto inacabado, socialmente construído - como também o é a raça -, elemento constitutivo da identidade. Portanto, o controle da linguagem relaciona-se à memória, pois as narrativas olvidadas afetam sujeitos em sua dimensão individual e, em escala mais ampla, afetam a memória coletiva (POLLACK, 1992) e, enquanto objeto de disputa política, a memória manipulada à esteira da história oficial celebrativa, aliena o sujeito. Do ponto de vista jurídi$c o$, toda política de discriminação que restringe, em função da origem étnica, o "reconhecimento, o gozo ou o exercício, em igualdade de condições, dos direitos humanos e das liberdades fundamentais nos domínios político, econômico, social, cultural" (BRASIL, Art. $1^{\circ}$, s1, 1969), é considerada racismo, o alijamento do direito à memória é uma forma de racismo estrutural e estruturante da sociedade. A refutação da arte narrativa enquanto estratégia política (de dominação) é também racismo, pois, na medida em que a linguagem escrita é imposta, não se trata mais de escolha, mas de intencionalidade deletéria a uma concepção plural e democrática de sociedade.

Esta discussão remonta à colonização dos territórios latino-americanos, como no caso do Brasil invadido pelos portugueses em 1500 d. C. - embora a história oficial por 
13. "Colonialidade do poder é um conceito que dá conta de um dos elementos fundantes do atual padrão de poder, a classificação social básica e universal da população do planeta em torno da ideia de 'raça'", (QUIJANO, 2002, p. 4). muito tempo tenha obrigado à versão da "descoberta". A normalidade social atual erigiu-se do massacre e exploração da força de trabalho de negros e índios, não cidadãos privados de qualquer sentido de dignidade ou direitos - fala-se aqui do controle não apenas da matriz intangível das suas origens, mas da sangria de corpos que foram desumanizados. Furtar-se de problematizar a interação cultural - tal qual já foi demonstrado, no que tange à relação travada com a oralidade - é fomentar que não mais a colonização, mas a colonialidade ${ }^{13}$ se protraia sobre os corpos e saberes, impedindo a realização de uma independência de fato e não apenas de direito.

A racialização é fator impeditivo da liberdade, constituiu-se numa marcação fenotípica e cultural, demarcatória da linha abissal que generaliza, subalterniza e diferencia as sociedades não brancas dos países que dominam o mundo, conforme a perspectiva destes. Por outro lado, em cada um desses países subalternizados, "a lo largo de su historia, se ha instalado una matriz de construcción de alteridad racialmente marcada al interior, que sirve de base para los mecanismos de exclusión por parte de las élites que controlan el Estado y sus recursos". (SEGATO, 2017, p. 50). Há transmutação terminológica, mas sem que haja perda do sentido elementar da opressão. A colonização perfez-se em colonialidade e o imperialismo dialoga com os mecanismos de dominação real e simbólica que deturpam a representação social e legitimam as relações sociais baseadas nos critérios de classificação e exclusão (QUIJANO, 2009). A subalternização de grupos atende de forma sistemática aos interesses imperialistas e a divisão étnico-racial faz-se instrumento de controle. Enquanto os brancos, outrora colonizadores, 
mantêm a sua autoridade, os colonizados, postos à margem social, histórica, cultural, científica e geográfica, são desenhados com a pele não branca dos escravos e mestiços descendentes errantes que contestam, por uma questão de concepção, o sistema de divisão social étnico-racial.

A negação, repressão ou silenciamento das histórias, memórias e perspectivas de mundo de comunidades como Volta Miúda relacionam-se a circunstâncias históricas e políticas que matam, se não o corpo, a liberdade de discernimento daqueles que descendem desta tradição e são alijados de suas origens. Este contexto de opressão se desenvolve por meio do racismo epistêmico e também em outras dimensões de enfrentamentos, a exemplo do processo de sufocamento que sofre o quilombo de Volta Miúda em função do alastramento da monocultura do eucalipto capitaneado por empresas multinacionais. A ação deletéria das empresas se dá com a invasão das comunidades quilombolas, pulverização de agrotóxicos herbicidas/pesticidas por via aérea, captação ilegal de água e contaminação e seca de córregos e nascentes $^{14}$, e culmina na marginalização da comunidade local e precarização das condições de sobrevivência, conforme relata Brasília Firmina:

O Eucalipto tomô o mundo tudo. Por isso que num, tem nada pra povo comê mais. Porque é só Eucalipto que tem. E puxa muita água também. Aqui tinha uma lagoa, que nois pra ir, pra passar lá pra dentro, nois tinha que rodiar ela assim ó... Aí, assim, nois tava escutando "uuuuuuuuuh", a água saindo da lagoa, tem um bocotó fundo aí ó, aqui assim ó. A água descia lááá embaixo. Hoje a lagoa é pura lenha, madeira, não é. Não é varinha não, é madeira grossa que tem dentro da lagoa. (Brasília Firmina, 3 de março de 2019).
14. Denúncias obtidas no Vídeo-documentário "Cartografando Conflitos" (CORNAVACA et al, 2018). 
As palavras de Brasília Firmina manifestam, ainda, o racismo ambiental, além de epistêmico, a que a comunidade tem sido submetida, isso conforme a definição de Tânia Pacheco:

Chamamos de Racismo Ambiental às injustiças sociais e ambientais que recaem de forma implacável sobre grupos étnicos vulnerabilizados e sobre outras comunidades, discriminadas por sua 'raça', origem ou cor [...] O Racismo Ambiental não se configura apenas através de ações que tenham uma intenção racista, mas igualmente através de ações que tenham impacto racial, não obstante a intenção que lhes tenha dado origem. (PACHECO, 2008, p. 9).

É possível identificar pelo menos três aspectos que denotam o racismo ambiental: a desterritorialização da comunidade quilombola pela marginalização da população a direitos sociais, descaracterização da cultura e modo de vida, expropriação da terra por via direta e indireta. Pensar a manutenção da comunidade não se trata de discutir o seu isolamento, mas em refletir que o contato não se dê de forma hierarquizada e deletéria aos seus interesses e modos de existência particulares.

Decerto que as diferenças socioculturais, religiosas, econômicas intersectam-se e se influenciam mutuamente nos territórios colonizados, a dimensão relacional da interculturalidade fala sobre este intercâmbio, contudo, a sua leitura exige uma percepção crítica apta a perceber os conflitos que lhes são inerentes. A interpretação crítica intercultural trata-se de um processo dialógico e não acabado, definido por Catherine Walsh ([entre 2009 e 2019], p. 3) como "uma estratégia, ação e processo permanentes de 
relação e negociação entre, em condições de respeito, legitimidade, simetria, equidade e igualdade" que pugna pela desnaturalização dos lugares sociais que definem, a partir de características sociais e históricas, sujeitos como centrais e subalternizados e condicionam a experiência destes à marginalidade.

Compreender as possibilidades interpretativas a partir da interculturalidade crítica permite rechaçar estratégias de silenciamento ocultadas por uma interação acrítica, estratégias estas que muito longe de derivarem de uma decisão estética são pontos de ruptura que desfavorecem uma visão de mundo comunitária, dialógica e participativa. Dona Zelita (Joselita Aleixo Serafim, 24 de junho de 2018) dimensiona o impacto do silenciamento destas formas de ser e viver: "Ah, de vez im quando a saudade é tão grande, tão grande, que dá vontade de juntá meus pano e ir embora" mas o "embora" não é, necessariamente, lugar (geográfico). Ao expressar o sentimento de pesar, Dona Zelita fala sobre referências de vida que já não encontra mais na comunidade, a maneira cooperativa com que as relações se estabeleciam, "é uma saudade tão grande que dói tudo por dentro". Sua visão de mundo se contrapõe ao "pensamento dos brancos", de uma matriz colonial-capitalista, que segue os caminhos da mercadoria (KOPENAWA; ALBERT, 2015, p. 65).

A memória segue o fluxo de refutação de verdades e certezas e do alargamento de possibilidades de horizontes, a fala é força, porque gera movimento e ritmo e vida e ação (HAMPÂTÉ BÂ, 2010, p. 173), a palavra humaniza e, ao reconhecer que o seu silenciamento é vetor de uma política de apaziguamento/desumanização, trilhar o caminho que 
rememora os sons ocultos pelo silêncio é ratificar a pujança para liberdade que toca a palavra memorada.

Justiça social e justiça cognitiva são temas indissociáveis, sustenta Maria Paula Meneses (2016), e conjuntamente demandam a releitura da História e a ampliação de fontes e métodos desde o Sul - conceito associado às "epistemologias do Sul" (SANTOS, 2009, p. 7-18), que aduzem acerca da produção de conhecimento a partir da experiência e saberes de povos e individualidades subalternizadas, sob a perspectiva de que "todos os conhecimentos sustentam práticas e constituem sujeitos" (SANTOS, 2009, p. 49). Valendo-se da interculturalidade crítica, a hibridização entre forma e conteúdo comunicacional é apresentada como estratégia decoIonial. Isto significa admitir a oralidade na produção científica e pô-la, assim como os saberes que dela advêm, em meio hábil à sua disseminação, o que reforça a perspectiva e importância da rememoração como estratégia de dignificação e humanização das comunidades, haja vista que

restituir a humanidade ao 'homem negro', ultrapassar a exclusão epistémica e a negação ontológica a que tem estado sujeito, é uma das dimensões fundamentais de qualquer projeto de justiça. Enquanto desafio ético, a justiça cognitiva é uma condição para a mudança radical da injustiça trazida pelo projeto colonial-capitalista, onde a epistemologia, em lugar de ser singular, é vista como processo de negociação e diálogo entre saberes. (MENESES, 2016, p. 176).

Retomando a oralidade e o seu poder de criação, Hampâté Bâ (2010, p. 172) explica que "sendo a fala a exteriorização das forças, toda manifestação de uma só força, seja 
qual for a forma que assuma, deve ser considerada como sua fala. É por isso que no universo tudo fala: tudo é fala que ganhou corpo e forma". A tangência da palavra passa, também, pela escrita que, numa perspectiva libertária, não Ihe seja mecanismo de legitimação, mas instrumento performático de transmissão e difusão àqueles que, ainda que não partilhem do contexto local da narrativa, possam dela beber e (res)significar a própria existência. O sujeito moderno é, inevitavelmente, um indivíduo de fronteiras - aprender sobre uma possibilidade decolonial de existência é ampliar seu próprio horizonte de buscas, para além da homogeneização e liquidez incutidas pela modernidade hegemonizada.

De certa forma, abrir espaço à fala é prover novas possibilidades de sentir. A escarificação promovida pela sociedade industrial é anestésica ou, no mínimo, desencorajadora da vida. "O homem moderno, imerso na multiplicidade de ruídos e informações, vê suas faculdades se atrofiarem progressivamente" (HAMPÂTÉ BÂ, 2010, p. 208) - e, por isso, tornam-se cada vez mais raros os narradores. A condição para (re)descobrir um (novo) mundo é exatamente esta: "saber esquecer seu próprio mundo" e "saber renunciar ao hábito de julgar tudo segundo critérios pessoais" (HAMPÂTÉ BÂ, 2010, p. 212). Trata-se de reaprender a sentir e a perceber o outro - não mais como o opressor. Aimé Cesáire (1978, p. 23-24), ao tecer crítica ao colonialismo, escreve, no contexto após a II Guerra Mundial, acerca do racismo e compara-o ao nazismo, alertando: o "colonizador, para se dar boa consciência, se habitua a ver no outro o animal, se exercita a tratá-lo como animal, tende objetivamente a transformar-se, ele próprio, em animal", em razão do que se defende que o principal exercício decolonial é ver ao próximo como ser humano para, quem sabe assim, humanizar-se. 
Narrar, memorar, é traduzir-se, continuar-se a partir da exteriorização de uma perspectiva de vida particular e única. Ao passo em que ouvir, capacidade muito antes olvidada do que a extinção de narradores (BENJAMIN, 1994, p. 205), é componente elementar do encontro de que necessita o diálogo. E é a problematização crítica do ambiente limítrofe que evoca a discussão sociopolítica e exige o desempenho de estratégias para a materialização de uma alternativa de vida e conhecimento aos sujeitos modernos e que são, intrinsecamente, decoloniais e discordantes das estratégias de dominação pela abstração da humanidade. Nesse ensejo, compreendendo-se que a ciência é uma das linhas demarcatórias das disparidades é que se insere a proposição de diálogos a acessar estas vivências olvidadas pela modernidade eurocentrada e em formato eficiente à sua difusão, em especial, em ambientes formais de ensino, concebendo-se, então, a ideia da criação de um livro composto por perfis biográficos de anciãs e anciãos de uma comunidade quilombola, Volta Miúda, pertencente ao município de Caravelas, no Extremo Sul da Bahia, a partir da oralidade. Compreende-se, portanto, que as lembranças da escravidão advêm da continuidade possibilitada pelo diálogo com ascendentes e a fronteira em que se insere, do pós-abolição, o faz ponte que transcende as experiências para o presente. São memórias coletivas que, conforme Maurice Halbwachs (2006, p. 30), permanecem “porque jamais estamos sós. Não é preciso que outros estejam presentes, materialmente distintos de nós, porque sempre levamos conosco certa quantidade de pessoas que não se confundem". 
豆 



\section{A dignificação da identidade quilombola a partir das memórias}

A promoção da interação com vistas a contribuir com a justiça social e cognitiva perpassa pela compreensão do próprio conceito/categoria designada pelo termo "quilombo". Ao levantar os significados que lhe são atribuídos, José Maurício Arruti (2006, p. 121) assevera que a "categoria 'remanescente de quilombos' é um exemplo privilegiado de como o poder simbólico de nomeação depositado no Estado pode, ao menos em parte, criar as próprias coisas nomeadas". O antropólogo elucida que o termo "quilombo" sofreu um processo de ressemantização ao longo dos séculos, e se refere ao termo "remanescente quilombola" como uma "alquimia semântica" (ARRUTI, 2006, p. 70), cercado de certo tom mitológico e metafórico, carregado de simbolismo cultural e histórico. Outrora entendido como reunião de escravos fugidos, o termo quilombo passou a ser visto como instituição de resistência cultural, visto que reúne, simbolicamente, os modos de ser e viver dos povos africanos escravizados e seus descendentes (ARRUTI, 2006, p. 72); resistência política, ao evidenciar e situar a disputa de poder entre classes / 
segmentos sociais que se opõem, com vistas a alcançar, para além da preservação da sua cultura, a luta contra a escravidão como sistema econômico e social (ARRUTI, 2006, p. 7375); e, também aborda o uso do quilombo enquanto "ícone da 'resistência negra'". A agregação do termo "remanescente" passou a evocar a existência em substância - e não apenas reminiscências memoriais - da presença negra africana e descendente como conformadora da sociedade.

Ao rememorar Abdias do Nascimento, Arruti contempla uma novação semântica do termo, pois, para aquele autor, "Quilombo não significa escravo fugido. Quilombo quer dizer reunião fraterna e livre, solidariedade, convivência, comunhão existencial" (NASCIMENTO, 1980, p. 263 apud ARRUTI, 2006, p. 76), de maneira que "comunidade quilombola" se realiza não apenas em coletividades que remanescem de quilombos, mas em todas que se apresentam como ícones de resistência dos modos de vida afrocentrados, como Volta Miúda. A ressemantização culmina, portanto, na noção de uma coletividade de origem sócio-histórico-cultural comum, oriunda de negros escravizados ou não, que agrega as noções de resistência política e cultural - que os coloca como coletivo hábil à luta pelo reconhecimento e percepção de direitos e cidadania.

O termo quilombo é uma categoria jurídica usada pelo Estado brasileiro a partir da Promulgação da Constituição Federal de 1988, visando assegurar a propriedade definitiva às comunidades negras rurais dotadas de uma trajetória histórica própria e relações territoriais específicas, bem como ancestralidade negra relacionada com o período escravocrata. Nesse sentido, há outras terminologias para o termo quilombo, como Terras de Preto, Terras de Santo, Mocambo, Terra de Pobre, entre outros. (SANTOS; ROCHA, 2017, p. 2). 
A supressão do termo "remanescente", apesar de simples, reverbera na ampliação do conceito já apresentado por Abdias Nascimento, que abdica do critério estritamente histórico - que renuncia a ideia de uma continuidade de um quilombo no período escravista até os dias atuais para abarcar a trajetória das comunidades que desempenham o papel de resistência cultural. De acordo com a professora da Faculdade de Educação da Universidade de Brasília (FE/ UnB) e pesquisadora da realidade quilombola, Glória Moura, "a realidade quilombola e sua forte influência na história de resistência do negro no Brasil" tem importância "para toda a História do país e a reafirmação da identidade étnica dos brasileiros" (FUNDAÇÃO CULTURAL PALMARES, 2012). E neste âmbito reforça: manter-se sensível à escuta das memórias e saberes de anciãs/os quilombolas é, ao mesmo tempo, contribuir para a efetivação da humanidade tanto de ouvintes quanto de narradores, e possibilitar-lhes a efetivação do direito à memória. Quilombo se concebe enquanto resistência num processo político em que há concorrência de forças e o desenvolvimento de estratégias para preservação da sua história, cultura e religiosidade, acessíveis, especialmente, por meio da história oral.

Brasília Firmina manifesta suas memórias como combatentes à racialização e hierarquização social. Além de tecer duras críticas à monocultura do eucalipto, ao relacioná-la ao estado socioeconômico reservado à comunidade, outrora rica em sua diversidade e fertilidade, expressa sua visão de mundo comunalista: "O eucalipto tomou o mundo todo, por isso que não tem nada pra povo comer mais [...] Porque só eles ganha e os outro não ganha? Vive de quê?", questiona a quilombola ao ressaltar que "Deus deixou o mundo 
muito grande, [se hoje falta alimento e água] é porque um só quer abraçar o mundo todo" (Brasília Firmina, 3 de março de 2019). O conhecimento da Volta Miúda de um tempo passado instala em Brasília Firmina a consciência de que não há determinismo em sua trajetória, e que as diferenças que percebe hoje advêm da ação direcionada de uma força político-econômica a quem responsabiliza pelos infortúnios vividos no presente, e ausentes no passado. O posicionamento de Dona Brasília denota não apenas racionalidade, mas uma inteligência crítica para a leitura da sua realidade.

O desfazimento dos modos de ser e viver afrocentrados fomentado, sobretudo, em função da imposição dos modos de ser e viver capitalista reverbera na vida de Berta d'Ajuda que, inserta num contexto quilombola e rural, é afetada pelo sistema colonial-capitalista que promove o apagamento das suas heranças socioculturais e mitiga a convivência, o caráter comunitário/humanista do grupo:

[...] O pessoal era muito unido, o pessoal da Volta Miúda. O pessoal perdia tempo pra ficá a semana toda ajudando você fazer quaqué coisa, trabalhá, ajudá né. Era muito unido, agora num é tanto mais assim. É mas não é. Igualmente, hoje em dia ninguém qué disprendê hora pra ajudar ninguém fazer nada. Hoje em dia não qué perdê, só qué sabê do dinheiro. Mais pra ir ver à toa, perdêassim, só ajudá sem dinheiro, ninguém qué perdê. Se tivé dinheiro você consegue, se não tivé, faz sozinho. (Berta d'Ajuda, 20 de fevereiro de 2019).

Berta fala sobre um modelo de sociedade que vulnera a existência de individualidades formadas sob valores que dissonam da mercantilização da vida. Sentimento e sentido - 
de vida, de mundo, de sociedade - são termos que dialogam. Berta sente falta da comunhão e proximidade que recheava, durante a sua infância e juventude, a sua convivência com as famílias quilombolas - cuja relação não se fundava no capital. Mas, ao reconhecer esta saudade, o faz com cautela, sem desfazer daqueles com quem ainda divide a vida de maneira interligada, conectada.

Manoel de Delfina é rezador do Santo Ofício, autoridade nas comunidades do Extremo Sul baiano, filho de Delfina Joaquina Josefa e neto de Joaquina Josefa, sempre destaca que a sua avó nasceu "no dia em que libertaram os escravo", foi nesta data, 13 de maio de 1888, que as bisavós e bisavôs de Seu Manoel, escravizados, foram libertos. Ele conhece de perto as ruínas da antiga senzala, e apresenta os arcos em pedra, um canal que desemboca no Rio Peruípe, a escadaria em pedra que leva a um terreiro e repete "isso aqui foi os escravo que fez" (Manoel de Delfina, 3 de março de 2019). A sua fala remete a um tom de apropriação sobre a realização arquitetônica dos seus antepassados - enquanto as mãos deslizam sobre a superfície plana e regular construída em pedra -, ao passo em que o tom elogioso é temperado pela inquietude da reflexão sobre 'como' a fizeram: lapidaram, carregaram, ergueram e assentaram pedras. Ao rememorar e tocar, literalmente, as reminiscências de um passado hostil e tão presente, Manoel de Delfina reflete sobre o seu vínculo com este território, de maneira salutar, afetiva, simbiótica, e afirma categoricamente: "Na cidade eu fico preso" (Manoel de Delfina, 3 de março de 2019) - ele desafia os limites da própria liberdade e questiona o conceito da famigerada (e moderna, no sentido histórico do conceito) liberdade. 
Ao contar sobre a forma como aprendeu o Santo Ofício, Manoel de Delfina ressalta "Eu sou nascido e criado aqui, nascido e criado em Volta Miúda. Nascido e criado dentro da Volta Miúda. E aprendi a cantá o Ofício, sem ninguém me ensiná, graças a Deus" (Manoel de Delfina, 8 de fevereiro de 2019) e abre, pelo menos, duas interpretações possíveis: a que aduz sobre o seu alijamento da participação ativa na sacralidade, pois, embora participasse do rito, Ihe foi negado o ensinamento por quem o conduzia, conforme relatou, e a capacidade de apreensão por meio da escuta e em decorrência da tomada da oralidade como modalidade precursora de conhecimento. Ao contar sobre a forma como se tornou rezador do Santo Ofício, Manoel de Delfina sempre enfatiza que aprendeu por observar, aprendeu a partir da experiência, ouvindo, sem que Ihe ensinassem. Exercia ele, por força das suas ancestralidades, o aprendizado a partir da oralidade e que se dá de maneira imbricada com as experiência do/ no mundo, pois

\footnotetext{
Uma vez que se liga ao comportamento cotidiano do homem e da comunidade, a "cultura" africana não é, portanto, algo abstrato que possa ser isolado da vida. Ela envolve uma visão particular do mundo, ou, melhor dizendo, uma presença particular no mundo - um mundo concebido como um Todo onde todas as coisas se religam e interagem. (HAMPATÉ BÂ, 2010, p. 169).
}

A tradição oral é lida como conhecimento total, passado pelos mais velhos aos mais novos, àqueles que tenham ouvidos sensíveis para aprender conhecimentos preservados há muitas gerações. Manoel de Delfina, ao reconhecer anciãs e anciãos como detentores de sabedoria e experiência 
acumulada durante a vida, reconheceu-os também como emissores, por excelência, do conhecimento total, manteve-se sensível e apreendeu o Santo Ofício.

É nesse mesmo ensejo que Berta d'Ajuda (20 de fevereiro de 2019) conta que aprendeu a fazer beiju, construir casa de taipa, plantar, fazendo, junto aos seus. Há, por parte da convivência estimulada nos modos de vida negra, uma transmissão de conhecimento que é orgânica, inerente à sua identidade, culturalmente intrínseca - que concebe e é originada por este modo particular de aprender e ensinar. A experiência como método de aprendizagem/experimentação está interligada à oralidade, haja vista que,

Ao fazer uma caminhada pela mata, encontrar um formigueiro dará ao velho mestre a oportunidade de ministrar conhecimentos diversos, de acordo com a natureza dos ouvintes. Ou falará sobre o próprio animal, sobre as leis que governam sua vida e a "classe de seres" a que pertence, ou dará uma lição de moral às crianças, mostrando-Ihes como a vida em comunidade depende da solidariedade e do esquecimento de si mesmo, ou ainda poderá falar sobre conhecimentos mais elevados, se sentir que seus ouvintes poderão compreendê-lo. Assim, qualquer incidente da vida, qualquer acontecimento trivial pode sempre dar ocasião a múltiplos desenvolvimentos, pode induzir à narração de um mito, de uma história ou de uma lenda. Qualquer fenômeno observado permite remontar às forças de onde se originou e evocar os mistérios da unidade da Vida, que é inteiramente animada pela Se, a Força sagrada primordial, ela mesma um aspecto do Deus Criador. (HAMPATÉ BÂ, 2010, p. 184). 
Ao se referir sobre o processo de construção das casas, derrubada da mata, plantio e colheita e beneficiamento da mandioca, Manoel de Delfina e Brasília Firmina relembram com cânticos o processo de ajuntamento e cooperação coletiva, que também demonstra a divisão sexual do trabalho:

Brasília Firmina: Pra ocê vê. Juntava pra fazer uma roça, tinha que juntar um bocado de homem. Tinha que juntar os home pra derrubar; as mulhé tá aí no rancho, que não tinha casa, num rancho pra fazer comida pros trabalhador, pros home. Aí os home cantava, cantava, com pouco a gente "olha vai cair derradeira madeira". Como é que a gente cantava? Derradeira madeira?

Manoel de Delfina: "Ô laranjeiro pá, ô laranjeiro pá, a madeira vai cair, ô laranjeiro pá."

B.F.: Vai cair derradeiro, e as mulhé que tá aí no rancho sabe. "Ó já tá terminando, vamo prontar a bandeira" - fazia duas bandeira de pano.

M.D.: Duas bandeira, tinha uma branca, outra azul.

B.F.: Marrada na ponta de uma vara assim ó, fica esgueiro assim. Quando os home é vem chegando, as mulher sai. Duas mulher, sai com essas duas bandeira cruzada, ainda cruzada e ia andando, quando chegava na porta entregava os home, vinha dois home também de lá recebia... a bandera. Como é que eles cantava?

M.D.: “Ó a bandera, bandera, ó bandera de iaiá, ó bandera, a bandera..."

B.F.: Agora a machadeira vem então com o machado: "dú, dú, dú".

M.D.: “Ó derrubada já acabou, ó bandeira, ó bandeira, 
oi bandeira. No poder do bastião, ó bandeira. 'Pelo siná, pelo siná', bandera do rei que é vem tomar."

B.F.: Quando cantava assim é a hora que as mulher ia entregar a bandeira. "'Pelo siná, pelo siná', bandeira do rei que é vem tomar". Quem vem tomar essa bandeira? "Bandera do rei que é vem tomar". Agora a gente entrega a eles a bandera e eles entra lá pra dentro com as bandera. Um monte de coisa de tempo. Naquele tempo... (24 de junho de 2018).

O pesquisador Gean Santana (2014, p, 141-142), ao rememorar o canto e o trabalho das negras e negros como celebração à vida, elucida que:

As bandeiras, assim como os tambores caburé e angoma, materializam a presença do divino no meio do povo negro. Não raro observarmos, nas casas de santo, a presença de um mastro que sustenta uma bandeira com bordados ou pinturas, representando o santo de devoção. Em Helvécia, constatamos uma forte devoção a São Sebastião [assim como em Volta Miúda], mártir católico, muito cultuado nos terreiros de culto de matriz africana, sincretizado no orixá Ogun.

O diálogo cantado é o enunciado duplo da integração construída pela cena: a narrativa fala sobre o exercício coletivo e cooperativo, ao passo em que a narração se estabelece num único ritmo em que compartilham e se complementam as memórias de Dona Brasília e Manoel de Delfina, há um intercâmbio dotado de sacralidade na representação da cena. O diálogo concebe-se em dança que entrelaça e exercita a memória de existências e humanidades que se realizam reciprocamente. O trabalho coletivo em prol do benefício de 
todos em função do atendimento à precisão dos con-viventes remete à afroperspectiva Ubuntu, que

pode ser traduzido como "o que é comum a todas as pessoas". A máxima zulue xhosa, umuntu ngumuntu ngabantu (uma pessoa é uma pessoa através de outras pessoas) indica que um ser humano só se realiza quando humaniza outros seres humanos. A desumanização de outros seres humanos é um impedimento para o autoconhecimento e a capacidade de desfrutar de todas as nossas potencialidades humanas. O que significa que uma pessoa precisa estar inserida numa comunidade, trabalhando em prol de si e de outras pessoas. (NOGUERA, 2012, p. 148).

Esta posição ratifica uma perspectiva de vida não afetada pelo racismo e/ou outras formas de hierarquização social. Os quilombolas de Volta Miúda são narradores, pois, além de recordar, têm a capacidade de transportar, com riqueza de detalhes e sonorizações, a si e a seus ouvintes à participação no fato contado, "de modo que seus ouvintes, assim como ele próprio, tomem-se testemunhas vivas e ativas desse fato" (HAMPATÉ BÂ, 2010, p. 210-211). As narrativas gravam cenas e contextos, e perpetuam sentimentos, incitam a reflexão, em prece, tecem a descolonização dos saberes.

Conversando com voz macia e firme, Manoel de Delfina ensina sobre as suas ancestralidades: "Minha bisavó era dos escravo; minha mãe nasceu da minha avó Joaquina no dia em que libertaram os escravo. Eu não sou do tempo dos escravo, mas ainda alembro do canto e das reza" (9 de fevereiro de 2019). O quilombola revela as histórias com performances que incluem palmas, cantos e danças, expressões de 
uma musicalidade que the é inerente, que aduz à vivacidade das suas origens. Santana (2014, p. 21), explica que:

Os cantos-poemas acionam reminiscências, evocam lembranças, cooperando para desconstruir as engrenagens e estruturas do engenho, as quais persistem na memória coletiva e revelam o chicotear que dilacerou corpos e mentes que não se submeteram aos mecanismos de poder e aos construtos de escravidão; as palavras cantadas trazem, entre o dito e o não dito, marcas de resistência, de poder e de magia, uma itinerância de morte e vida severa, contudo, libertária.

Dança e canto são rememorados e reconfigurados como espaços de resistência. Manoel de Delfina, durante incursão às ruínas da senzala, apontando para um terreiro com base em pedra, conta: "Treze de maio tinha bate barriga, que era festa de antigamente. É alegria porque terminou os escravo. 13 de maio. Ó, só vendo... 13 de maio, dia que a minha avó, mãe da minha mãe nasceu" (Manoel de Delfina, 3 de março de 2019). Brasília Firmina explica que a dança bate-barriga era "pra festejar [a liberdade] (...) Pr'a um bate barriga falava tambô. "Vai tê samba de tambô!'" (24 de junho de 2018). Nesse contexto,

a dança bate-barriga assume uma duplicidade de significação, ela é uma dança - expressão de movimento, bailado, samba e sentimento corpóreo-sensorial - como também é o lugar, o local onde reside um volume de estilhaços 
de memória. Um refúgio em que as lembranças se agregam à espera da composição da dança para se manifestarem, se recomporem; a dança e os dançantes como locais de resíduos possíveis de serem restaurados como performances. (DOS SANTOS, 2007, p. 84-85).

Noutros espaços de memória, a musicalidade também reflete embates de luta e conquista, sobre continuidade e vida implicada com a coletividade. Brasília Firmina conta sobre uma experiência íntima que, ao falar sobre uma ex-escravizada, conecta não apenas ela, mas a comunidade de Volta Miúda à sua herança africana:

\begin{abstract}
Minha bisavó quando trovejava ela tinha toalha, tinha roupa de conversá no tempo. Trovoada podia tá falando mesmo, ela marrava esse pano na cabeça, uma toalha branca, botava uma bacia com uma pedra dentro... uma bacia dessa bacia piquena e saía no tempo. Conversava, conversava, falava num sei o quê, não sei o quê lá, língua deles que ninguém sabe, falava, falava, daí a poco a trovoada tá trovejando lá longe. Não trovejava mais não. (3 de março de 2018).
\end{abstract}

Brasília (3 de março de 2018) fala também sobre a Mãe d'Água, e sobre a cantoria feita à beira da lagoa encantada para salvar uma moça que sumira no olho d'água, esta rememoração compreende o:

processo de reconhecimento, uma luta em busca das raízes e razões de ser quilombo, as mulheres, com seus cantos da Mãe d'Água, agricultoras e mãos hábeis de bordadeiras, almejam, de forma rizomática, diversa 
singularidade constituída no tempo e que delineia, de forma diferente, o ser e o agir, por meio de manifestações sócio-culturais e religiosas que parecem apontar para uma resistência e a manutenção de uma identidade construída ao longo dos enfrentamentos identitários ou dos jogos de poder, expressos em suas cantorias. (SANTANA, 2014, p. 71).

A escuta e escrita dessas memórias visam propiciar a que outras pessoas possam conhecer a Comunidade Quilombola de Volta Miúda e ser incentivadas à retomada da sua história e da primorosa habilidade como narradoras e narradores, (re)humanizando-se no presente, ampliando as possibilidades de interpretação sobre a sua própria existência e a dos quilombolas que resistem. Sob o lume das memórias, tecem-se alternativas decoloniais, cujas experiências e sensibilidade e fé e força poetizam a luta a fim de que outras trajetórias individuais e coletivas iluminem-se por uma história rica, múltipla, hábil a identificar a negritude e afrodescendência como símbolos de força e resistência.

O professor e doutor em filosofia Renato Noguera (2012, p. 147) chama de afroperspectiva "o conjunto de pontos de vista, estratégias, sistemas e modos de pensar e viver de matrizes africanas". Este é um convite para imersão no pluriverso de sentidos evocados pela vivência com as/os quilombolas de Volta Miúda... imersão que visa proporcionar a descolonização de perspectivas, práticas... para conduzir à revisitação das trajetórias individuais e do contexto sócio-histórico-político que o sistema colonial- capitalista impõe. Sigamos avante - ninguém solta a mão de ninguém. 
Manoel Reis, ao contar sobre a forma como se tornou rezador do Santo Ofício, enfatiza que aprendeu por observar, aprendeu a partir da experiência, ouvindo. Nas tradições africanas, a tradição oral é lida como conhecimento total, passado pelos mais velhos ao mais novos, àqueles que tenham ouvidos sensíveis - livres de pré-conceitos para aprender conhecimentos preservados há muitas gerações. Anciãs e anciãos são reconhecidos por toda a sabedoria e experiência acumulada durante a vida, e isso os dignifica.

Brasília Firmina fala sobre uma experiência íntima que, ao contar sobre uma ex-escrava, conecta não apenas ela, mas a comunidade remanescente de Volta Miúda à sua origem africana e à resistência que, com luta, conquistou a liberdade e a vem ressignificando ao encontrar espaços que ecoem sua voz.

Este livro, ao incentivar a retomada da sua história àqueles sujeitos e da sua primorosa habilidade como narradoras e narradores, (re)humaniza-os no presente, amplia aos leitores as possibilidades de interpretação sobre a sua própria existência, ensina aos mais jovens sobre uma história rica, múltipla, hábil a definir a cor da sua pele como símbolo de força e resistência. Sob o lume das memórias fala sobre vivências decoloniais, cujas experiências e sensibilidade e fé e força poetizam a luta e tecem resistência. 
豆 



\section{Reflexões finais}

Sentir é uma forma de manifestação política. O termo "política" é polissêmico - ou seja, possui vários significados a depender do contexto em que seja aplicado - mas, nesta frase, é utilizado como sinônimo de poder em disputa. O silenciamento histórico, a opressão cultural e epistêmica (da produção do conhecimento), a marginalização social, a discriminação racial são sintomas de um mesmo processo de disputa política, em que um modelo de sociedade - capitalista, colonialista, eurocentrada - se impõe, por meio da força, como única alternativa possível. Estar sensível a perceber a realidade, a entender o processo de violência que, historicamente, marginaliza, desumaniza, afasta os quilombolas (e afrodescendentes, em geral) do acesso à cidadania é portar-se contrariamente àqueles que oprimem.

O que falam os quilombolas de Volta Miúda? Que leitura de mundo é possível fazer a partir das narrativas das anciãs e anciãos? As mulheres e homens quilombolas falam, sobretudo, acerca das suas experiências - mas não de forma egoísta -, que é, também, uma perspectiva da memória coletiva daquela comunidade, haja vista que "recordar é algo muito mais do que simplesmente reproduzir fatos, trata-se de um processo de reconstrução seletivo e parcial que 
depende das pertenças e redes sociais dos indivíduos" (CABECINHAS; LIMA; CHAVES, 2006, p. 70). As/Os quilombolas de Volta Miúda falam a partir e sobre uma herança histórica e cultural dos modos de ser, viver e sentir que advêm das negras e negros que foram escravizados e trazidos de vários países da África ao Brasil, falam sobre "afroperspectivas" que, segundo o professor e doutor em filosofia Renato Noguera (2012, p. 147), referem-se ao "conjunto de pontos de vista, estratégias, sistemas e modos de pensar e viver de matrizes africanas".

Ao fazer uma pesquisa livre na internet sobre o termo "resistência", é possível identificar diversos significados que remetem a não ceder, opor-se, manter-se firme, subsistir. A decolonialidade aduz sobre um movimento iniciado por intelectuais latino-americanos que preconizavam a compreensão da modernidade por perspectivas de individualidades que foram, historicamente, subalternizadas em função do contexto capitaneado pela própria modernidade - cuja face oculta é o mundo periférico colonial.

Este livro se insere no já não novo discurso que visa problematizar a independência política e a abolição da escravatura como marcos não libertários, a fim de evidenciar que forma e matéria, discurso e prática, gozam de distâncias abissais. Protraindo-se colonialismo em colonialidade, escravidão em exclusão social, resistir é portar-se sensível a perceber a existência do outro - esse outro não como agente exógeno, mas como a própria face reflexa em um espelho cuja humanização define a sua própria humanidade.

O exercício de humanizar-se e a outrem, portanto, implica levar às comunidades humanas, rurais e urbanas, 
quilombolas ou não, do Extremo Sul da Bahia e para além dele, histórias de uma comunidade quilombola, que são leituras de mundo que resistem, que se opõem à colonialidade que coisifica o ser. As memórias das/os quilombolas de Volta Miúda são poesias, falam sobre sentimento, sobre um mundo real e abstrato, ensinam sobre sensibilidade, cooperação e vidas que existem em sua inteireza se e somente se imbricadas umas as outras.

Este caminho desenvolveu-se desde a concepção da questão central, compelindo a um processo cíclico de reflexão, dúvidas, leituras e escrita, e, sobretudo, desconstrução. Ao me debruçar sobre a averiguação da educação enquanto linguagem hegemônica e excludente, ou linha abissal (SANTOS, 2009), em análise das constituições brasileiras ${ }^{15}$, e da percepção da multidiversidade étnica-cultural da sociedade brasileira, verifiquei que, inobstante os avanços alcançados no período de 2002-2016, no âmbito da democratização da educação, quanto ao acesso e permanência, o ensino formal possui uma densa carga de exclusão das identidades subalternizadas, tais como os afrodescendentes. Concluí quanto à (in)existência de um direito contemplativo das etnias conformadoras da sociedade brasileira, haja vista que uma educação não colonizadora

[...] implica, sobretudo, num caminhar inverso, pois o sentido de desenvolvimento pretendido não coagiria o sujeito a tornar-se ou apreender conceitos, vestimentas, linguagens, sentimentos que lhe são, em verdade, extrínsecos. O sentir que ultrapassa os moldes eurocêntricos - e por isso inexplicável - é o sentido que aglutina populações secularmente oprimidas, mas de particularidades vivazes em resistência ao empobrecimento capitaneado pela homogeneização imperialista.
15. Denúncias obtidas no Vídeo-documentário "Cartografando Conflitos"

(CORNAVACA et al, 2018). Trabalho intitulado "Evolução do direito à educação no Brasil sob a perspectiva pós-colonial", apresentado no XXVII Encontro Nacional do Conselho Nacional de Pesquisa e PósGraduação em Direito (CONPEDI) e publicado na Revista de Direito Sociais e Políticas Públicas (ALMEIDA, 2018). 
Ao postular a revolução epistêmica e jurídica, que implicaria em profundas transformações das estruturas sociais, é importante notar que o que se pleiteia é a abertura política - de fato - às vozes silenciadas. Romper com o silenciamento, entretanto, não significa promover o isolamento e distanciamento de tais grupos. É, numa oposição às verdades postas, inclusive, ao raciocínio legitimado, consentir numa existência multíplice. Mestras e mestres dos saberes são, nesta perspectiva, símbolos de um processo de reflexão intrínseca que exige olhar para si e enxergar a ancestralidade que, viva, se manifesta na desarmonia de modelos que não cabem, e se mantém inaudível e ininteligivel, por ser cartesianamente inalcançável.

[...] A amplitude do território histórico, epistêmico e cultural a ser (re)descoberto, com vistas à desconstituição das práticas impregnadas pela lógica colonialista - sobretudo as perpetuadas sem o reconhecimento desta mácula - que permeiam os ambientes social, escolar e demais espaços onde se renovam as arbitrariedades, deve continuar a instigar a luta pelo alcance da liberdade e dignidade humanas, com vistas à equalização do passivo sócio-histórico-cultural brasileiro. A fim de que, assim, os estudos sobre o avanço ou desenvolvimento do direito à educação, numa perspectiva pós-colonial, remeta pesquisadores e leitores a um novo lugar epistêmico do que seja, inclusive, educação ou direito. (ALMEIDA, 2018, p. 58-59).

Trazer as memórias ao papel, utilizando-se das linguagens verbal e não verbal, respeitando ao máximo as construções frasais e opções temáticas da/os quilombolas, contribui à ruptura com a linguagem hegemônica acadêmica livresca, pois, conforme CABECINHAS \& NHAGA (2008, p. 114), "todos os indivíduos são activos na construção das suas representações; no entanto, a estrutura social determina que nem todos têm igual margem de liberdade no 
processo de negociação das representações". A rememoração de caminhos, em lugar da texturização de uma versão singular sobre cultura ou história, traveste-se de reconstrução histórica para exercício libertário, pois

\begin{abstract}
implica quebrar o pacto de silêncio sobre o passado escravo, celebrado entre os cidadãos brasileiros livres em plena vigência da escravidão [...] apresenta-se paradoxalmente como caminho possível para reverter tal processo de hierarquização cristalizado no tempo e instaurar um universalismo almejado, mas não verdadeiramente atingido, desde o século retrasado. (MATOS; ABREU, 2004, p. 19).
\end{abstract}

A imersão em Volta Miúda, desde os primeiros passos e diálogos, evocou a beleza e riqueza das histórias ocultas, que são instrumentais para a emancipação cognitiva da comunidade. Esta emancipação está diretamente ligada, inclusive, à ruptura com a própria ficção da dignidade humana no discurso jurídico, que é eurocentrado, burguês, uma voz das classes dominantes. A vivência em Volta Miúda informou o protagonismo do capital para a subjugação dos povos e comunidades originários, que se quedam vulneráveis às imposições, violências e alijamento de direitos sociais, culturais e econômicos elementares. Isto reflete, de maneira mais abrangente, numa reexistência ante a colonialidade instaurada sob os valores da modernidade e que pretere os sentidos comunitarista, não produtivista e humanista comuns aos coletivos pesquisados. Limitar as individualidades a um tipo específico de dignidade humana é, também, uma forma de aprisioná-las. A vida digna em Volta Miúda, a partir dos perfilados, não está na propriedade, na acumulação de riquezas, mas na força intangível da comunidade que, unida e 
integrada, garantia a dignidade e felicidade coletivas - isto difere da dignidade pautada pelo capital.

Os apontamentos aqui articulados se estabelecem no espectro de princípios éticos e científicos que percebem as pessoas, em especial as mais velhas, como píncaros de saber; que reconhecem a experiência como fonte de ciência; que se opõem, resistem, arduamente, às estratégias de dominação que tentam homogeneizar, coisificar, desensinar sobre sentir, minar a autoconfiança - apontamentos que ambicionam contribuir à salvação das gerações vindouras dos perigos de uma história única. Estas memórias, concedidas sensivelmente pelas anciãs e anciãos de Volta Miúda, rompem os limites da comunidade e os ressignificam. São histórias e memórias de resistência, que ampliam horizontes, poetizam a luta diuturna em prol de uma sociedade plural e fraterna e iluminam existências.

Volta Miúda me ensinou a ser continuidade, não há considerações finalísticas, o que existe em mim é a certeza de um vínculo que me antecede e que me excede. As vivências compartilhadas com os quilombolas desta localidade ensejam, diariamente, novas inquietações e buscas. Em função disso, estou desenvolvendo um trabalho acadêmico em que primo por extrair dos modos de ser, viver e sentir da comunidade, uma gramática jurídica decolonial. Para isso, é preciso refletir que a humanidade em sua dimensão digna se realiza por critérios muito específicos a partir das afroperspectivas.

Este livro, enquanto ato memorial, é um brevíssimo relato de sentimentos e percepções que, tenho certeza, maturarão com o tempo. É o relato de uma trajetória forte, 
extenuante, que me rejuvenesce, fortalece, que me faz crescer pessoal e profissionalmente - e que ressignificou a minha militância em prol da chamada equidade e justiça social.

Vejam só: este é o meu tributo às anciãs e anciãos da Comunidade Quilombola de Volta Miúda. Gostaria de citá- los nominalmente, mas por precaução, a fim de que eu não incorra em nenhuma distração, fraternalmente dirijo-me a todas e todos quilombolas de Volta Miúda, às minhas/meus entrevistadas/os, a todas/os com quem compartilhei risos e sorrisos, informações, conversas, olhares, cumprimentos e experiências, às queridas professoras e funcionárias da Escola Municipal Dr. Sócrates Ramos, às adoráveis crianças com quem tive o prazer de dialogar; dirijo-me, carinhosamente, àquelas/es que ainda virão, fiz este trabalho pensando, também, em vocês.

Certamente este ciclo está marcado pela descoberta de novos caminhos a serem percorridos, da retomada de fôlego e fortalecimento da fé que possuo na força inerente à convivência coletiva, na efetivação do direito à memória como estratégia para salvar-nos da estupidez que conduz esta sociedade e macula a nossa liberdade. Sigo acreditando que a justiça social é possível, e mais consciente sobre as formas com que posso contribuir para isso - especialmente, seguirei rememorando nossos diálogos, a manter-me sensível à percepção de que sempre há algo a aprender, se me mantiver no horizonte do mundo que me nutre.

Este é o meu agradecimento por compartilharem um pouco de si, agradecimento por contribuírem com o meu sonho de evidenciar formas decoloniais de vida - que são vidas de fato, que resistem ante o sistema colonial-capitalista que 
coisifica e nos desensina a sentir. Este percurso é o retrato de que sentir, é, de fato, uma habilidade revolucionária. Sob - lume das memórias dos quilombolas de Volta Miúda, em prece, concluo a que meus passos sejam guiados e multiplicados pela senciência que (re)existe através da sua ancestralidade. 
豆 



\section{Dicas de leitura}

\section{Afroperspectivas}

HAMPÂTÉ BÂ, Amadeu. A tradição viva. In: KI-ZERBO, Joseph. (ed.). História Geral da África: metodologia e préhistória da África. Brasília: UNESCO, 2010. v. 1. p. 167-212.

NOGUERA, Renato. Ubuntu como modo de existir: elementos gerais para uma ética afroperspectivista. Revista da ABPN, [S.I.], v. 3, n. 6, p. 147-150, nov. 2011 - fev. 2012.

NOGUERA, Renato. O poder da infância: espiritualidade e política em afroperspectiva. Momento: diálogos em educação, Rio Grande do Sul, v. 28, n. 1, p. 127 142, jan./abr. 2019. Disponível em: https://periodicos.furg. $\mathrm{br} / \mathrm{momento} /$ article/view/8806. Acesso em: 19 maio 2019.

\section{Colonialismo e colonialidade}

CARMO, Alane Fraga. Colonização e escravidão na Bahia: a Colônia Leopoldina, 1850-1888. 2010. Dissertação (Mestrado em História Social) - Faculdade de Filosofia e Ciências Humanas, Universidade Federal da Bahia, Salvador, 2010. 
CÉSAIRE, Aimé. Discurso sobre o colonialismo. Lisboa: Livraria Sá da Costa Editora, 1978.

QUIJANO, Aníbal. Colonialidade do poder e classificação social. In: SANTOS, Boaventura de Souza; MENESES, Maria Paula (Org.). Epistemologias do Sul. Coimbra: Edições Almedina, 2009. p. 73-117.

\section{Educação decolonial}

ALMEIDA, Raíssa Félix. Evolução do direito à educação no Brasil sob a perspectiva pós-colonial. Revista de Direito Sociais e Políticas Públicas, Salvador v. 4, n. 1, p. 41-62, janeiro - junho 2018.

SANTOS, Boaventura de Sousa. Por uma concepção multicultural de direitos humanos. Revista Crítica de Ciências Sociais, Coimbra, n. 48, p. 11-32, jul./1997.

SANTOS, Boaventura de Sousa. Para além do pensamento abissal: das linhas globais a uma ecologia de saberes. In: SANTOS, Boaventura de Souza; MENESES, Maria Paula (Org.). Epistemologias do Sul. Coimbra: Edições Almedina, 2009. p. 23-71.

WALSH, Catherine. Interculturalidade Crítica e Educação Intercultural. [entre 2009 e 2019]. Disponível em: pt.scribd.com/document/227507643/InterculturalidadeCritica-e-Educacao-Intercultural--Carherine-Walsh. Acesso em: 19 de maio 2019. 


\section{Memória}

BOSI, Ecléa. Memória e sociedade: lembranças de velhos. 3. ed. São Paulo: Cia das Letras, 1994.

LE GOFF, Jacques. História e memória. 5. ed. São Paulo: Editora da Unicamp, 2003.

POLLACK, Michel. Memória e identidade social. Estudos Históricos, Rio de Janeiro, v. 5, n. 10, p. 200-212, 1992.

\section{Negritude e racialidade}

BRASIL. Decreto $\mathbf{n} .^{\circ} \mathbf{6 5 . 8 1 0}$, de 8 de dezembro de 1969. Convenção Internacional sobre a Eliminação de Todas as Formas de Discriminação Racial. Disponível em: www2.camara.leg.br/atividadelegislativa/ comissoes/comissoespermanentes/cdhm/comitebrasileirode-direitos-humanos-e-politica-externa/ ConvIntElimTodForDiscRac.html. Acesso em: 20 de maio 2019.

MUNANGA, Kabengele. Por que ensinar a história da África e do negro no Brasil de hoje? Revista do Instituto de Estudos Brasileiros, Brasil, n. 62, p. 20-31, dez. 2015.

MENESES, Maria Paula. A questão negra entre continentes: possibilidades de tradução intercultural a partir das práticas de luta? Sociologias, Porto Alegre, ano 18, n. 43, p. 176-206, set./dez. 2016. 
SEGATO, Rita. Racismo, discriminación y acciones afirmativas: herramientas conceptuales. In: SEPTIEN, Rosa Campoalegre; BIDASECA, Karina (Org.). Más allá del decenio de los pueblos afrodescendentes. Buenos Aires: Clacso, 2017. p. 43-63.

DAVIS, Angela. Mulheres, Raça e Classe. Tradução Heci Regina Candiani. 1. ed. São Paulo: Boitempo, 2016.

\section{Quilombos}

ARRUTI, José Maurício. Mocambo: antropologia e história do processo de formação quilombola. Bauru: EDUSC, 2006.

FUNDAÇÃO CULTURAL PALMARES. Comunidades Remanescentes de Quilombos. 2020. Disponível em: http: / / www.palmares.gov.br/comunidadesremanescentes-dequilombos-crqs. Acesso em: 4 de out. 2020.

RIOS, Ana Lugão; MATTOS, Hebe Maria. Memórias do cativeiro: família, trabalho e cidadania no pós-abolição. Rio de Janeiro: Civilização Brasileira, 2005.

SANTANA, Gean Paulo Gonçalves. Vozes e versos quilombolas: uma poética identitária e de resistência em Helvécia. 2014. Tese (Doutorado em Letras) - Programa de Pós-Graduação em Letras, Pontifícia Universidade Católica do Rio Grande do Sul, Porto Alegre, 2014. 
豆 


\section{referências}

ABRAMOVICH, Víctor; COURTIS, Christian. "Hacia la exigibilidad de los derechos económicos, sociales y culturales - Estándares internacionales y criterios de aplicación ante los tribunales locales". In: La aplicación de los tratados sobre derechos humanos por los tribunales locales. Editores del Puerto: 1997, ISBN 987-9120-14-0, págs. 283-350.

ALBERTI, Verena. Manual de história oral. Rio de Janeiro: Editora FGV, 2005.

ALBERTI, Verena. Fontes Orais: história dentro da História. In: PINSKY, Carla Bassanezi (org.). Fontes Orais. São Paulo: Contexto, 2007. p. 155202.

ALEIXO, Joselita. Entrevista concedida a Raíssa Félix. Volta Miúda, Caravelas/BA, 24 jun. 2018.

ALMEIDA, Raíssa Félix. Evolução do direito à educação no Brasil sob a perspectiva pós-colonial. Revista de Direito Sociais e Políticas Públicas, v. 4, n. 1, p. 41-62, janeiro - junho 2018.

ARRUTI, José Maurício. Mocambo: antropologia e história do processo de formação quilombola. Bauru: EDUSC, 2008.

BAHIA. Lei $\mathbf{n} .^{\circ} \mathbf{4 . 4 5 2}$ de 09 de maio de 1985. Cria o Município de Teixeira de Freitas, desmembrado dos de Alcobaça e Caravelas, e dá outras providências. Disponível em: http://www.camaratf.ba.gov. $\mathrm{br} / \mathrm{wp}$-content/uploads/2011/O3/Lei-4452-1985-CRIA-OMUNIC\%C3\%8DPIO-DE-TEIXEIRA-DE-FREITAS.pdf. Acesso em: 10 mar. 2019. 
BALANDIER, Georges. A situação colonial: abordagem teórica. Caderno Ceru, [S.I], série 2, v. 25, n. 1, p. 33-58, junho de 2014.

BENJAMIN, Walter. O narrador: observações sobre a obra de Nikolai Leskow. In: Obras escolhidas de Walter Benjamin. V. 1., São Paulo: Brasiliense, 1994. p. 197-220.

BISPO, Antônio. Colonização, Quilombos: modos e significados. Brasília/ DF: INCTI/UNB, 2015.

BRASIL. Decreto n. ${ }^{\circ}$ 65.810, de 8 de dezembro de 1969. Convenção Internacional sobre a Eliminação de Todas as Formas de Discriminação Racial. Disponível em: www2.camara.leg.br/atividade-legislativa/ comissoes/comissoes-permanentes/cdhm/comite-brasileiro-dedireitos-humanos-e-politica-externa/ConvIntElimTodForDiscRac.html. Acesso em: 20 de maio 2019.

BRASIL. Constituição da República Federativa do Brasil: promulgada em 5 de outubro de 1988. Disponível em: www.planalto.gov.br/ccivil_03/ Constituicao/Constituicao.htm. Acesso em: 20 abr. 2017.

BRASIL. Lei de Diretrizes e Bases da Educação (LDB), Lei n. ${ }^{\circ}$ 9394/96. Disponível em: http://www.planalto.gov.br/ccivil_03/lei/1996/9394.htm. Acesso em: 20 mar. 2019.

BRASIL. Decreto n. ${ }^{\circ} \mathbf{4 . 2 2 8}$, de 13 de maio de 2002. Institui, no âmbito da Administração Pública Federal, o Programa Nacional de Ações Afirmativas e dá outras providências. Disponível em: http://www.planalto.gov.br/ ccivil_03/decreto/2002/d4228.htm. Acesso em: 30 mar. 2018.

BRASIL. IBGE. Pesquisa Nacional por Amostra de Domicílios, 2003. Síntese de indicadores sociais. 2003. Disponível em: ftp://ftp.ibge.gov. $\mathrm{br} /$ Indicadores_Sociais/Sintese_de_Indicadores_Sociais_2003/. Acesso em: 30 mar. 2018.

BRASIL. FCP, Fundação Cultural Palmares. Certificação Quilombola. 2020. Disponível em: http://www.palmares.gov.br/sites/mapa/crqsestados/crqs-ba-20072020.pdf. Acesso em: 03 out. 2020. 
BRASIL. Lei $\mathbf{n} .^{\mathbf{1}}$ 10.639, de 9 de janeiro de 2003. Altera a Lei n. 9.394 , de 20 de dezembro de 1996. Disponível em: http://www. planalto.gov.br/ ccivil_03/leis/2003/110.639.htm. Acesso em: 30 mar. 2018.

BRASIL. Lei $\mathbf{n} .^{\mathbf{1}} \mathbf{1 1 . 6 4 5}$, de 10 de março de 2008. Altera a Lei n. ${ }^{\circ} 9.394$, de 20 de dezembro de 1996. Disponível em: http://www.planalto.gov. br/ccivil_03/_ato2007-2010/2008/lei/111645.htm. Acesso em: 30 mar. 2018.

BRASIL. Decreto n. ${ }^{\circ} \mathbf{6 . 8 7 2}$, de 4 de junho de 2009. Aprova o Plano Nacional de Promoção da Igualdade Racial - PLANAPIR, e institui o seu Comitê de Articulação e Monitoramento. Disponível em: http://www. planalto.gov.br/ccivil_03/_ato2007-2010/2009/decreto/d6872.htm. Acesso em: 30 mar. 2018.

BRASIL. IBGE. Censo. Caravelas. Características da população e dos domicílios. 2010. Disponível em: https://cidades.ibge.gov.br/brasil/ba/ caravelas/. Acesso em: 12 jul. 2018.

BRASIL. IBGE. População estimada: IBGE, Diretoria de Pesquisas, Coordenação de População e Indicadores Sociais, Estimativas da população residente com data de referência $1^{\circ}$ de julho de 2020 a. Disponível em: https://cidades.ibge.gov.br/brasil/ba/caravelas/ panorama. Acesso em: 31 ago. 2020.

BRASIL. IBGE. Síntese de Indicadores Sociais - SIS. 2020b. Disponível em: https://www.ibge.gov.br/estatisticas/sociais/saude/9221-sintesede-indicadores-sociais.html?=\&t=downloads. Acesso em: 31 ago. 2020.

BRASIL. Lei n. ${ }^{\mathbf{1 2}} \mathbf{2 8 8}$, de 20 de julho de 2010. Institui o Estatuto da Igualdade Racial. Disponível em: http://www.planalto.gov.br/ccivil_03/_ ato2007-2010/2010/lei/112288.htm. Acesso em: 30 mar. 2018.

\section{BRASIL. Diretrizes Curriculares Nacionais para a Educação Básica:}

diversidade e inclusão. CRAVEIRO, Clélia Brandão Alvarenga; MEDEIROS, Simone (Org.). Brasília: Conselho Nacional de Educação: Ministério da Educação, Secretaria de Educação Continuada, Alfabetização,

Diversidade e Inclusão, 2013. 
BRASIL. IBGE. Pesquisa Nacional por Amostra de Domicílios, 2016. Síntese de indicadores sociais. Disponível em: ftp://ftp.ibge.gov.br/ Indicadores_Sociais/Sintese_de_Indicadores_Sociais_2016/. Acesso em: 30 mar. 2018

BRASIL. Mídias na Educação. Ministério da Educação. 2005. Disponível em: http://webeduc.mec.gov.br/midiaseducacao/material/impresso/ imp_basico/index.html.. Acesso em: 21 nov. 2017.

BOBBIO, Norberto; MATTEUCCI, Nicola; PASQUINO, Gianfranco.

Dicionário de Política. Brasília: Editora Universidade de Brasília, 1998.

BOSI, Ecléa. Memória e sociedade: lembranças de velhos. 3. ed. São Paulo: Companhia das Letras, 1994.

BOURDIEU, Pierre. O poder simbólico. Rio de Janeiro: Editora Bertrand Brasil S. A., 1989.

CABECINHAS, Rosa; LIMA, Marcus; CHAVES, Antônio. Identidades nacionais e memória social: hegemonia e polémica nas representações sociais da história. In: MIRANDA, Joana; JOÃO, Maria Isabel (ed.). Identidades Nacionais em Debate. Oeiras: Celta, 2006. p. 67-92. Disponível em: http://repositorium.sdum.uminho.pt/ bitstream/1822/6165/1/Cabecinhas-Lima-Chaves-2006.pdf. Acesso em: 20 mar. 2019.

CABECINHAS, Rosa; NHAGA, Nesilita. Memórias coloniais e diálogos póscoloniais: Guiné-Bissau e Portugal. In: CABECINHAS, Rosa; CUNHA, Luís (ed.) Comunicação intercultural: perspectivas, dilemas e desafios. Porto: Campo das Letras, 2008, p. 109-132.

CAMPELLO, Tereza (Coord.). Faces da desigualdade no Brasil: um olhar sobre os que ficam para trás. Brasil: FLACSO, Faculdade LatinoAmericana de Ciências Sociais, CLACSO, Consejo Latinoamericano de Ciencias Sociales, Fundação Ford, 2017. 
CARMO, Alane Fraga. Colonização e escravidão na Bahia: a Colônia Leopoldina, 1850-1888. 2010. Dissertação (Mestrado em História Social) - Faculdade de Filosofia e Ciências Humanas, Universidade Federal da Bahia, Salvador, 2010.

CÉSAIRE, Aimé. Discurso sobre o colonialismo. Lisboa: Livraria Sá da Costa Editora, 1978.

CÉSAR, Chico. Deus me proteja de mim. Francisco, forró e frevo. CD. São Paulo: EMI, 2008.

CHAUÍ, Marilena. Prefácio. In: BOSI, Ecléa. Memória e sociedade: lembranças de velhos. 3. ed. São Paulo: Companhia das Letras, 1994. p. 17-33.

CORNAVACA, Trinidad et al. Vídeo-documentário Cartografando

Conflitos. Seminário Memórias, lutas sociais e processos de reconciliação no Sul - Conselho Latinoamericano de Ciências Sociais - CLACSO,

Centro de Estudos Sociais da Universidade de Coimbra - CES/UC. 2018.

CARTOGRAFANDO CONFLITOS. Produção de Trinidad Cornavaca et al. Conselho Latinoamericano de Ciências Sociais - CLACSO, Centro de Estudos Sociais da Universidade de Coimbra - CES/UC, 2018.

D'AJUDA, Berta. Entrevista concedida a Raíssa Félix. Volta Miúda,

Caravelas/BA, 20 fev. 2019.

DELFINA, Manoel de. Entrevista concedida a Raíssa Félix. Volta Miúda, Caravelas/BA, 24 jun. 2018.

DELFINA, Manoel de. Entrevista concedida a Raíssa Félix. Volta Miúda, Caravelas/BA, 8 fev. 2019.

DOS SANTOS, Valdir Nunes. As manifestações culturais em Helvécia no Estremo Sul da Bahia: a dança bate-barriga como fabricante de performances afrodescendentes. 2007. Dissertação (Mestrado em Teatro) - Universidade do Rio de Janeiro/Faculdades Integradas São Pedro, Rio de Janeiro, 2007. 
FÉLIX, Raíssa. Livro didático e o ensino de história: perspectivas de (des)colonização na comunidade quilombola de Volta Miúda. Encontro Estadual de História da Associação Nacional de História - Seção Bahia (ANPUH-BA). Santo Antônio de Jesus, 2018. Disponível em: http:// Www.encontro2018.bahia.anpuh.org/resources/anais/8/1532385351_ ARQUIVO__Livrodidaticoeoensinodehistoria_perspectivasde(des) colonizacaonacomunidadequilomboladeVoltaMiuda.pdf. Acesso em: 5 jul. 2020.

FIRMINA, Brasília. Entrevista concedida a Raíssa Félix. Volta Miúda, Caravelas/BA, 3 mar. 2019.

FLICK, Uwe. Introdução à pesquisa qualitativa. 3. edição. Porto Alegre: Artmed, 2009.

FUNDAÇÃO CULTURAL PALMARES. Comunidades Remanescentes de Quilombos (CRQ's). 2012. Disponível em: http://www.palmares.gov.br/ comunidades-remanescentes-de-quilombos-crqs. Acesso em: 5 nov. 2017.

GROSFOGUEL, Rámon. Para descolonizar os estudos de economia política e os estudos pós-coloniais: transmodernidade, pensamento de fronteira e colonialidade global. Revista Crítica de Ciências Sociais, Coimbra, n. 80, p. 115-147, 2008.

HALBWACHS, Maurice. A memória coletiva. São Paulo: Ed. Centauro, 2006.

HAMPATÉ B , Amadeu. A tradição viva. In: KI-ZERBO, Joseph (ed.). História Geral da África: metodologia e pré-história da África. Brasília: UNESCO, 2010. v. 1. p. 167-212.

HENRIQUES, Isabel de Castro. Colônia, colonização, colonial e colonialismo. In: SANSONE, Lívio; FURTADO, Cláudio Alves (org.). Dicionário crítico das ciências sociais dos países de fala oficial portuguesa. Salvador: EDUFBA, 2014. p. 45-58. 
HONORATO, Cláudio de Paula. Valongo: o mercado de escravos do Rio de Janeiro, 1758 a 1831. 2008. Dissertação (Mestrado em História) - Instituto de Ciências Humanas e Filosofia, Universidade Federal Fluminense, Niterói, 2008.

KILOMBA, Grada. Memórias da plantação: episódios de racismo cotidiano. Rio de Janeiro: Cobogó, 2019.

KLINK, Amyr. Cem dias entre céu e mar. São Paulo: Companhia das Letras, 2011.

KOPENAWA, Davi; ALBERT, Bruce. A queda do céu: palavras de um xamã Yanomami. Companhia das Letras: São Paulo, 2015.

LE GOFF, Jacques. História e memória. 5. ed. São Paulo: Editora da Unicamp, 2003.

MALDONADO-TORRES, Nelson. Sobre la colonialidad del ser: contribuciones al desarrollo de un concepto. 2007. Disponível em: http://ram-wan.net/restrepo/decolonial/17-maldonadocolonialidad\%2Odel\%2Oser.pdf. Acesso em: 13 jun. 2019.

MARTINS, Gilberto de Andrade; THEÓPHILO, Carlos Renato. Metodologia da investigação científica para ciências sociais aplicadas. São Paulo: Atlas, 2007.

MARX, Karl. Contribuição à crítica da Economia Política. 1859. (Obras escolhidas, tomo 1). Disponível em: <https://www.marxists.org/ portugues/marx/1859/contcriteconpoli/introducao.htm>. Acesso em: 13 jun. 2019 .

MATTOS, Hebe Maria, ABREU, Marta. "Remanescentes das Comunidades dos Quilombos": memória do cativeiro, patrimônio cultural e direito à reparação. Dossiê Novas etnicidades no Brasil: Quilombolas e índios emergente. Berlim: IberoAmerikanisches Institut, 2011, Ano XI, n. 42, pp. 147-160.

MENESES, Maria Paula. Ampliando las epistemologías del sur a partir de los sabores: diálogos desde los saberes de las mujeres de mozambique.

Revista Andaluza de Antropología, n. 10, p. 10-28, mar./2016. 
MUNANGA, Kabengele. Mestiçagem como símbolo da identidade brasileira. In: SANTOS, Boaventura de Souza; MENESES, Maria Paula (Org.). Epistemologias do Sul. Coimbra: Edições Almedina, 2009. p. 444-454.

MUNANGA, Kabengele. Por que ensinar a história da África e do negro no Brasil de hoje? Revista do Instituto de Estudos Brasileiros, Brasil, n. 62, p. 20-31, dez. 2015.

NASCIMENTO, Abdias do. O quilombismo: documentos de uma militância pan-africanista. São Paulo: Editora Perspectiva; Rio de Janeiro: Ipeafro, 2019.

NOGUERA, Renato. Ubuntu como modo de existir: elementos gerais para uma ética afroperspectivista. Revista da ABPN, [S.I] v. 3, n. 6, p. 147-150, nov. 2011 - fev. 2012.

NUNES NETO, Francisco Antonio. Interdisciplinaridade e interculturalidade: mestres e mestras dos saberes no Ensino de História na Escola Básica. Revista FSA, v. 13, n. 2, p. 126-148, mar/abr. 2016.

PACHECO, Tânia. Desigualdade, injustiça ambiental e racismo: uma luta que transcende a cor. Inequality, environmental injustice, and racism in Brazil: beyond the question of colour. Development in Practice, $v .18, n$. 6, nov. 2008. Disponível em: https://racismoambiental.net.br/textose-artigos/desigualdadeinjustica-ambiental-e-racismo-uma-luta-quetranscende-a-cor/. Acesso em: 13 jun. 2019.

PIOVESAN, Flávia. Temas de Direitos Humanos. 7. ed. São Paulo: Saraiva, 2014.

POLLACK, Michel. Memória e identidade social. Estudos Históricos, Rio de Janeiro, v. 5, n. 10, p. 200-212, 1992.

QUIJANO, Aníbal. Colonialidade do poder e classificação social. In: SANTOS, Boaventura de Souza; MENESES, Maria Paula (Org.).

Epistemologias do Sul. Coimbra: Edições Almedina, 2009. p. 73-117. 
QUIJANO, Aníbal. Colonialidade do poder, Eurocentrismo e América Latina. In: LANDER, Edgardo (org.). A colonialidade do saber:

eurocentrismo e ciências sociais. Perspectivas latino-americanas. Buenos Aires: CLACSO, Consejo Latinoamericano de Ciencias Sociales, 2005. p. 107-130. Disponível em: http://bibliotecavirtual.clacso.org.ar. Acesso em: 25 jan. 2018.

QUIJANO, Aníbal. Colonialidad y modernidad/racionalidade. Revista del Instituto Indigenista Peruano, Lima, v. 13, n. 29, p. 11-22, 1992.

RIOS, Ana Lugão; MATTOS, Hebe Maria. Memórias do cativeiro: família, trabalho e cidadania no pós-abolição. Rio de Janeiro: Civilização Brasileira, 2005.

SANTANA, Gean Paulo Gonçalves. Vozes e versos quilombolas: uma poética identitária e de resistência em Helvécia. 2014. Tese (doutorado em Letras) Pontifícia Universidade Católica do Rio Grande do Sul, Programa de Pós-Graduação em Letras. Universidade do Estado da Bahia, Programa de Pós-Graduação em Estudos de Linguagens, Doutorado Interinstitucional (DINTER), Salvador, Porto Alegre, 2014.

SANTOS, Boaventura de Sousa. Para além do pensamento abissal: das linhas globais a uma ecologia de saberes. In: SANTOS, Boaventura de Souza; MENESES, Maria Paula (Org.). Epistemologias do Sul. Coimbra: Edições Almedina, 2009. p. 23-71.

SANTOS, Eslania Correia dos; ROCHA, Joallan Cardim. As comunidades quilombolas no brasil: a luta pelo acesso a terra. IV Encontro Nacional e X Forum Estado, Capital, Trabalho. Universidade Federal de Sergipe, 2017. Disponível em: https://engpect.files.wordpress.com/2017/10/ gt2-11-as-comunidades-quilombolas-no-brasil.pdf. Acesso em: 19 jun. 2019 .

SCHERER-WARREN, Ilse. Movimentos sociais e pós-colonialismo na América Latina. Ciências Sociais, Unisinos, São Leopoldo, v. 46, n. 1, p. 18-27, jan./abr. 2010.

SEGATO, Rita. Racismo, discriminación y acciones afirmativas: herramientas conceptuales. In: SEPTIEN, Rosa Campoalegre; BIDASECA, Karina (Org.). Más allá del decenio de los pueblos afrodescendentes. Buenos Aires: Clacso, 2017. p. 43-63. 
SERAFIM, Domingos. Entrevista concedida a Raíssa Félix. Volta Miúda, Caravelas/BA, 9 jun. 2018.

SILVA, Silvane. Racismo e sexualidade nas representações de negras e mestiças no final do século XIX e XX. In: LOPES, Maria Aparecida de Oliveira (org.). História do negro no Brasil: escravidão, gênero, movimentos sociais e identidades. São Paulo: Premier, 2011. p. 161-182.

TAYLOR, Diana. O arquivo e o repertório: performance e memória cultural nas Américas. Belo Horizonte: Editora UFMG, 2013.

THOMPSON, Paul. A voz do passado: história oral. Rio de Janeiro: Paz e Terra, 1992.

TOURTIER-BONAZZI, Chantal. Arquivos: propostas metodológicas. In: AMADO, Janaína; FERREIRA, Marieta de Moraes (org.). Usos e Abusos da História Oral. 8 ed. Rio de Janeiro: Editora FGV, 2006.

VILAS BOAS, Sérgio. Perfis: e como escrevê-los. São Paulo: Summus, 2003.

VOGT, Carlos; FRY, Peter. Cafundó: a África no Brasil: linguagem e sociedade. São Paulo: Companhia das Letras, 1996.

WALSH, Catherine. Interculturalidade Crítica e Educação Intercultural. [entre 2009 e 2019]. Disponível em: pt.scribd.com/document/227507643/ Interculturalidade-Critica-e-Educacao-Intercultural-Carherine-Walsh. Acesso em: 19 maio 2019.

ZUMTHOR, Paul. Introdução à poesia oral. Belo Horizonte: UFMG, 2010. 
豆 


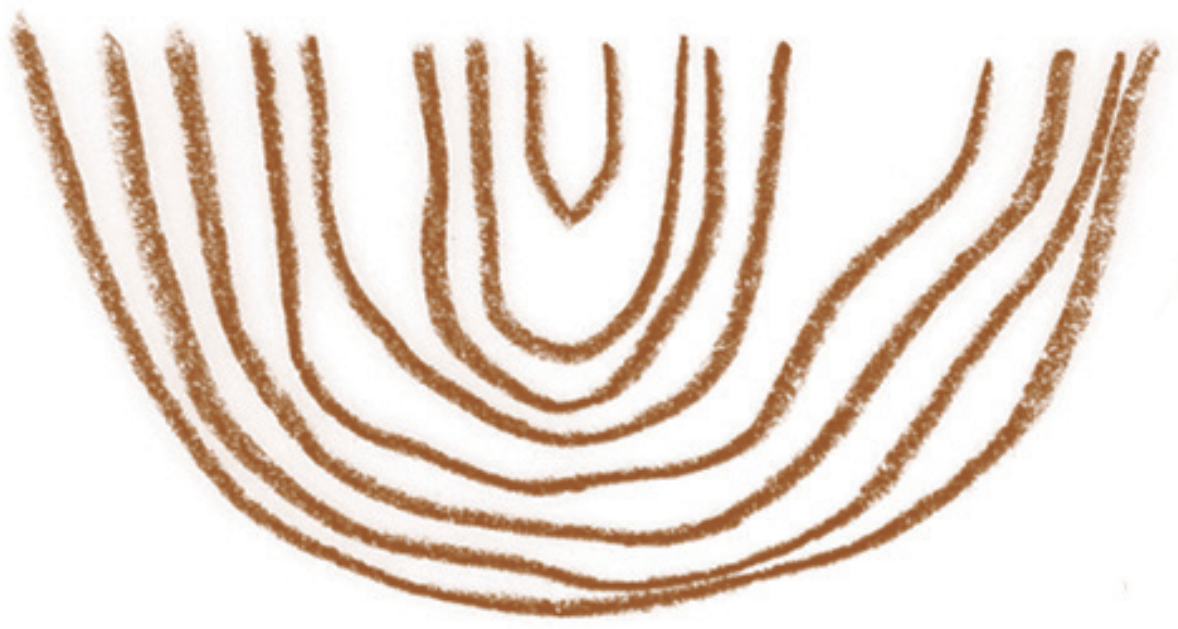




\section{posfácio}

TRANSFLUÊNCIA, LIVROS CONTRACOLONIAIS

\section{Transfluir: modos de pensar-fazer}

É preciso "superar o caráter autoritário do atual Estado Democrático de Direito", para que "toda e qualquer proposta de mudança seja exaustivamente debatida, respeitando-se as mais diversas formas de linguagem e de comunicação", escreve Antônio Bispo dos Santos (2015, p. 97), em livro intitulado Colonização, Quilombos: modos e significados.

O caminho para tal superação, nomeada pelo autor de "contracolonização", passa pela formulação de alguns conceitos teórico-metodológicos, como 'confluência', 'transfluência', 'tradutor entre mundos', 'reedição' de palavras, de narrativas e de epistemologias. Passa também pela escrita como campo de disputa, dispositivo a ser apropriado como "uma arma do inimigo para transformá-la em defesa" (SANTOS, 2018, s.p.).

Um entre esses modos de pensar-fazer, "transfluir", foi adotado por nós como nome da série de livros nascida de pesquisas de pós-graduação vinculadas à Universidade Federal do Sul da Bahia (UFSB). As três pesquisas que compõem a série saíram de cada uma das sedes da UFSB, 
divididas em três campi, constelados em rede e enraizados geopoliticamente nos municípios de Itabuna, Porto Seguro e Teixeira de Freitas.

Em agosto de 2020, firmando uma parceria interinstitucional com a Universidade Estadual de Santa Cruz (UESC), por meio de sua editora universitária, a Editus, o Programa de Pós-Graduação em Ensino e Relações Étnico Raciais (PPGER/UFSB) cria oficialmente a série de livros "Transfluência: Ensino, Gênero e Relações Étnico-Raciais”.

As três obras inaugurais dessa série foram selecionadas por meio de edital público. Puderam concorrer a esse edital todas/os que, na ocasião, estivessem vinculadas/os ao PPGER: discentes, docentes, grupos de pesquisa, comissões científicas de eventos ocorridos desde a abertura das atividades de formação do curso, em setembro de 2017. As três autorias selecionadas para os primeiros números da série são estudantes egressos da primeira turma de mestrandas e mestrandos do programa.

De modo geral, para estudantes de pós-graduação, a publicação de seus trabalhos, oriundos de projetos de pesquisas, pode significar reconhecimento público, amplo e estratégico de seus percursos formativos, escolhas e proposições teórico-metodológicas. Na tradição das Ciências Humanas, a publicação de livros é um dos caminhos para o tornar-se autor/a, reconhecida/o pelos pares. Mesmo assim, o trabalho de conclusão em nível de mestrado nem sempre toma o caminho do livro, parando no repositório institucional. Na contramão disso, esta série traz a questão da transposição da dissertação para livro, como processo formativo, como alargamento do raio de impacto dos trabalhos 
realizados no PPGER/UFSB. Além disso, põe em perspectiva o livro como retorno de pesquisas gestadas em escolas, quilombos, terreiros e aldeias, encorajando a expansão e o amadurecimento dos trabalhos de conclusão de curso no terreno da publicação como etapa legítima do desenvolvimento teórico-reflexivo.

No caso específico do PPGER, tais autorias são significativamente contra-hegemônicas, densamente territorializadas em comunidades de tradição oral, marcadamente dissidentes e insurgentes em seus contextos de produção e suas propostas epistemológicas. Participam, por essa via, do esforço de criação de diversas formas de linguagem para pesquisas resolutivas e mídias de comunicação que sejam capazes de abrir caminho à superação das colonialidades autoritárias de um Estado Democrático de Direito, que ainda não encontrou um conjunto de textos, uma convergência plural de diferentes sistemas de pensamento, capaz de assegurar os debates necessários ao viver em comum, sem a eliminação compulsória das diferenças.

\footnotetext{
Para Antônio Bispo dos Santos (2015, p. 89, grifos nossos),
}

confluência é a lei que rege a relação de convivência entre os elementos da natureza e nos ensina que nem tudo que se ajunta se mistura, ou seja, nada é igual". [...] [E contrapondo-se a essa lei,] transfluência é a lei que rege as relações de transformação dos elementos da natureza e nos ensina que nem tudo que se mistura se ajunta.

Em um tensionamento dos opostos, para Santos (2015), ainda seguindo as letras de seu livro, nós aprendemos 
a confluir com os povos da terra, com os povos de tradição oral (quilombolas, de terreiros, povos indígenas, afroindígenas, etc.), de lógica cosmovisiva circular; e aprendemos a transfluir com os povos de tradição escrita, com lógica cosmovisiva linear e pensamento monista.

Com o abandono dos tensionamentos binários, em nossas mãos, no ponto de encontro de diferentes águas, no encruzilhar de diferentes tradições civilizatórias, detenhamos nosso olhar nas lições aprendidas no livro de Bispo dos Santos (2015, p. 89): "nem tudo que se ajunta se mistura, ou seja, nada é igual" e "nem tudo que se mistura se ajunta".

Façamos assim para, então, indagar: até onde é possível compor uma série de livros em que se guardem - sejam transmitidos - gestos múltiplos, diferenças agonísticas, autorias dissidentes, saberes insurgentes e não hegemônicos, epistemologias contracoloniais, quando nos defrontamos com as colonialidades e o racismo estrutural de nosso atual Estado Democrático de Direito?

\section{Das águas: corpos e corpus}

Trabalho com os conceitos de "confluência" e "transfluência". Confluência foi um conceito muito fácil de elaborar porque foi só observar o movimento das águas pelos rios, pela terra. Transfluência demorou um pouco mais porque tive que observar o movimento das águas pelo céu. Para entender como um rio que está no Brasil conflui com um rio que está na África eu demorei muito tempo. E percebi que ele faz isso pela chuva, pelas nuvens. Pelos rios do céu. Então, se é possível que as águas doces que 
estão no Brasil cheguem à África pelo céu, também pelo céu a sabedoria do nosso povo pode chegar até nós no Brasil (SANTOS, 2018, s.p.).

Recomecemos de outro modo. Porque, sim, as águas têm memórias. Ficam nelas entranhadas tantos lugares por onde escorrem nas veias da terra, tantas gentes e saberes que com elas fluem. Para nós, são esses rios do céu, nas ensinanças de Antônio Bispo dos Santos (2018), que inspiram o projeto editorial da série de livros "Transfluência".

De como os rios de África chegam no Brasil. De como a distância territorial, o apartamento afrodiaspórico do território não apaga os elos, os saberes, os diferentes modos de ensinar e de aprender, a comunicação entre mundos. Feitiçaria que corre pelas águas trazendo recados, recuperando histórias subterrâneas dos lençóis freáticos, dos rios que correm e a-fluem a céu aberto, dos oceanos que fazem grandes conexões continentais. A feitiçaria como tradução, como quem extrapola o interlinguístico e habita o entre-lugar dos mundos, a articulação de modos dissidentes de existir, como "um intérprete a serviço da transmutação", como ensina Tiganá Santana (2018, p. 12).

Uma série de livros escritos por autoras e autores que também se arriscam como tradutoras e tradutores interculturais e pluriepistêmicos, como corpos cognoscentes, heteróclitos e transcriativos, escrevendo um corpus, conjunto de obras, heteróclito e transcriativo. Uma série de livros como coleção bibliográfica e materialidades de experiências de vida que são resultado das pesquisas e fortuna crítica para novas pesquisas. Pensamos aqui, mais uma vez, inspiradas por algumas noções metodológicas e teóricas de 
Antônio Bispo dos Santos (2018, s.p.) - "Minhas mais velhas e meus mais velhos me formaram pela oralidade, mas eles mesmos me colocaram na escola para aprender, pela linguagem escrita, a traduzir os contratos que fomos forçados a assumir"; pela noção de transcriação de Haroldo de Campos (2013); e, sobremaneira, pela noção de história, de Beatriz Nascimento (2018, p. 333) - “A memória são conteúdos de um continente, da sua vida, da sua história e do seu passado. Como se o corpo fosse o documento".

Em seguida, Célia Xakriabá (2020) nos diz que todo corpo é território e está em movimento, em permanente (re) territorialização. E, com isso, reivindica uma educação territorializada, ao contrário daquela desagregadora, característica historicamente encarnada pelas instituições formais de ensino. "Amansar o giz", então, é "ressignificar a escola", diz ela, no reconhecimento dos valores e dos elementos de cada corpo-território, como lugar potente de articulação entre saberes, mas sobretudo com o que o território nos alimenta, nos ensina e nos constitui (XAKRIABÁ, 2020, s.p.).

Passa um córrego, corre um rio submerso, em uma das cidades-sede do PPGER, Itabuna, cujo nome é Burundanga e sobre o qual uma escola pública foi construída. Um fragmento da memória desse corrégo-rio, degradado e tornado invisível a olho nu, torna-se legível para nós a partir de uma fala-escrita de Carlos Alberto Araújo dos Santos, Egbomin Alaboji, do llê Axé ljexá Orixá Olufon. Aqui vertida, em versão transcriada, uma narrativa brota reeditada: em uma cartografia geopolítica de mar de morros, os rios Burundanga e Jeribucassu caminham juntos, fazem parte da costa rochosa no litoral sul da Bahia. Córrego, rio, BURUNDANGA. Aqui, 
como nas Africanidades diaspóricas, as línguas, os corpos e as paisagens caminham juntos, perfazem encontros afroindígenas: Buru: enorme; Dan: serpente; Ga: alto. BURUNDANGA. A serpente que veio e nasceu do alto. Seixos de línguas: tupi, iorubá. Em relação à topologia cultural da nascente desse córrego, ou rio, dizemos: as águas descem do alto serpenteando. Dito de outro modo, "as águas descem sinuosas como uma enorme serpente". Nessa manhã inaugural, que perdura ainda, "em que o céu está em festa e mais colorido: a Serpente Sagrada do Povo Gege risca os Céus!”.

Temos aprendido com nossos mais velhos, pela oralidade e pela escrita. Reeditando narrativas, aprendemos. Somos feitos de muitas comunidades, de mil povos e incontáveis nações. As mais de mil nações dos povos originários, entre as quais estão os Tupinambá, os Pataxó, os Pataxó Hã Hã Hãe, que habitam regiões ancestrais e contemporâneas no Sul da Bahia e nos ensinam seus modos de fazer-pensar; e as nações diaspóricas africanas são muitas, sabem ser uma e ser mil, a uma só vez:

\begin{abstract}
A sobrevivência da cultura africana se fez no Brasil a partir de três grupos ou três nações: a Gege, que está quase acabando, a Ketu que domina hoje, que centraliza hoje uma ortodoxia, uma teologia que é Ketu-Nagô, porque há várias nações Nagôs e o Angola, que é talvez o sincretismo brasileiro dessas experiências africanas (NASCIMENTO, 2018, p. 333).
\end{abstract}

Sobrevivências, re-existências, corpos com memória de águas e das paisagens que habitamos. Atravessados 
por pensamentos, teorias, métodos, cartografias, biografias, narrativas, trajetos de pesquisas transfluentes, como bem sabem ser as águas das chuvas, dos rios, dos mares, dos mangues, da terra; e confluentes, como bem sabem ser as/os que perfazem diferentes ciclos de mundos no mundo. São com tais corpus e corpos que esperamos fazer compor e ampliar, ano a ano, a série aberta de livros "Transfluência: Ensino, Gênero, Relações Étnico-Raciais".

Um corpus, portanto, para a série "Transfluência", como corpo-território, corpo-documento, como política editorial, que deseja se alinhar às genealogias orais de linhagem de livros que se sabem atos estético-políticos, cognitivos e de ensino. Para essas linhagens, há escritas não alfabéticas. Escritas de águas. Escritas das matas. Escritas de milênios, como pinturas rupestres, cantos, ritmos poéticos e de pensamentos orais, inscrições, demarcações de passagens, não de posse, mas de pertencimento, de partilha de vida, de bem comum.

\section{Tipografias líquidas, livros contracoloniais}

Tendo tudo isso em vista, como chegar no livro? O livro como materialização das brechas e flechas lançadas pelo nome que abre caminho dessa série? Que visualidades podem o constituir? Como curá-lo em seus caminhos editoriais e projeto gráfico?

O livro, como território historicamente aliado dos abusos e estigmas do Estado de Direito, assume toda a estirpe colonial como objeto de catequização e domínio. Opõe-se à oralidade. Afirma a escrita logocêntrica, alfabética. 
Como pensar, porém, o livro de outro lugar? Como território potente de transformação, como trânsito entre mundos, como tramas interétnicas, como processos de subjetivação em trânsito, instáveis, dissidências, afirmação em devir.

Como pensar agora o livro aberto, o livro mundo? O livro para fora, nas comunidades escolares, nas comunidades de terreiro, nas comunidades quilombolas, no enfrentamento das questões de gênero e dissidências sexuais? O livro cuja página é a floresta, cujas linhas são lidas na caída dos búzios, cujas grafias são a pele e suas inscrições sábias do tempo no corpo, livros-peles, livros-lugares.

Reconhecer o livro fora dos domínios da colonialidade, ver o livro aberto, implicado no território, a transfluir águas. Nelas: entes, encantados, voduns, orixás, inkises, ritos, saberes, narrativas, orikis, rezas, geomitologias, os diferentes corpos que as habitam, muitas dimensões do humano e de diversas cosmopercepções.

Vejamos o livro de água gráfica, da nascente à foz, do mar aberto à areia da praia, da lama profunda à superfície do mangue, tantas escritas e inscrições: quando a água passa, perfaz caminhos, ranhuras, topografias. Tantas memórias fincadas no chão por onde ela passou. No correr da viagem de uma vida que faz um rio: muitas águas se encontram. $O$ encontro aqui é signo de movimento e mudança permanentes. O rio transcorre pelo território como uma cobra mudando de pele, na transmutação ligeira do espaço-tempo. É imperativo, sempre, continuar, como esta série de livros o fará.

O encontro é também faísca que transcorre quente, sinergia potente de criação, fricção. Quantos maus 
encontros promovidos pela colonização afro-pindorâmica, responsáveis por desterritorializações e reterritorializações monumentais e genocidas, transcorridas das águas de Áfricas embarcadas e aportadas nas Américas. Quantos encontros potentes de força encantatória também não se deram no bojo dessa invasão, tantas vezes reinstaurada no curso do tempo, entronizada no Brasil como projeto de normatização, sendo o encantamento "ato de desobediência, transgressão, invenção e reconexão: afirmação da vida” (SIMAS; RUFINO, 2020, s.p.).

As águas guardam, portanto, a memória desses tantos encontros de conexões afro-pindorâmicas, em diversas dimensões. Thiago de Melo (1984, p. 157-158) diz que as águas nunca se desgastam: "permanecem nas águas os elos das correntes invisíveis". Pois quantas marés há na memória da chuva? E na "maré dos olhos" como a "memória das corredeiras" que escapa do olhar perdido do velho Agodô no conto de Cidinha da Silva (2018)? "Devo contar o vivido, velho Agodô? Conte o que fizeste dele, minha filha. Isso basta, meu velho? Se basta não sei. Aviva" (SILVA, 2018, p. 27-28)? O corpo da terra, o corpo das gentes, corpo líquido, corpo vivo.

Se ainda é possível transfluir essas conexões, como nos convoca Antônio Bispo (2015, 2018), como os rios do céu que choram na chuva e nos trazem de volta memórias invisíveis, confluências continentais, fluxos e refluxos da transmutação da natureza, o livro aqui se coloca também como território de encontros. De modo que foi a água a chave-mestra do processo criativo do projeto gráfico desta série de livros, talhada em um conjunto de carimbos que, em 
relação, organizam e re-organizam múltiplos movimentos visuais. As águas e as cores. Cores terrosas, cores vibrantes. Tipografias líquidas. Nos carimbos, confluência de cores, de lógicas e de tempos históricos: a modernidade e a tradição sobrescritos no tempo presente. Carimbos gráficos, sulco artesanal na madeira, transposição ao digital, com combinações múltiplas, que denunciam sua técnica na textura, imperfeita e precisa, de fluxos vincados em sua matéria-prima. Gestos, traços de quem imprime como quem assenta na página percursos possíveis do macroterritório do Sul da Bahia. Essa é a nossa direção editorial.

\section{Agradecimentos}

Um livro, uma série de livros, não se concebe e nem se faz com poucas pessoas envolvidas. Há muito a agradecer. Mesmo correndo o risco de deixar de fora algum nome, e pedindo antecipadamente desculpas se isso ocorrer, agradecemos aos coordenadores locais do PPGER, Eliana Póvoas Pereira Estrela Brito e Gilson Brandão de Oliveira Junior. Ao coletivo de professores e discentes, e especificamente aqueles que trabalharam na Comissão de Seleção das obras: Hamilton Richard A. F. Santos, Francisco A. Nascimento Junior, Yuri Miguel Macedo (do campus Sosígenes Costa, PPGER Porto Seguro); Rebeca Valadão Bussinger, Francisco Antônio Nunes Neto, Paulo César Pereira de Jesus (do campus Paulo Freire, PPGER Teixeira de Freitas); Apoena Dandara Silva Santos (do campus Jorge Amado, PPGER Itabuna). Agradecemos a Rita Virgínia Argollo, Sabrina Nascimento, Conselho Editorial e toda equipe da Editus, parceria indispensável neste projeto. À equipe de revisores, José Pedro de 
Carvalho Neto e Tess Chamusca Pirajá. À equipe de artistas gráficos, Lia Cunha e Tiago Ribeiro. Às instituições Universidade Federal do Sul da Bahia e Universidade Estadual de Santa Cruz, com suas equipes de servidores públicos que viabilizaram cada passo do processo. Agradecemos aos autores que inauguram esta série de livros: Raíssa Félix, Kauan Almeida e Ademar Cirne, pelas trocas e aprendizados mútuos nesta tarefa de fazer chegar ao mundo dos livros seus percursos de pesquisa. Agradecemos, por fim e por início, a Kabengele Munanga: nosso mais velho, companhia que nos honra, nos fortalece, nos alegra, ao nos acolher e nos ensinar tanto e ao modo firme dos aquilombamentos ancestrais.

Cynthia Cy Barra e Laura Castro

Coordenação Editorial do Projeto Transfluência Itabuna; Salvador, Bahia, outubro de 2020. 


\section{REFERÊNCIAS}

CAMPOS, Haroldo de. Tradição, transcriação, transculturação: o ponto de vista do excêntrico. In: TÁPIA, Marcelo; NÓBREGA, Thelma Médici (org.). Haroldo de Campos - Transcriação. São Paulo: Perspectiva, 2013. p. 197-205.

MELO, Thiago. Vento geral. Rio de janeiro: Civilização Brasileira, 1984.

NASCIMENTO, Maria Beatriz. Beatriz Nascimento: intelectual e quilombola. Possibilidade nos dias da destruição. São Paulo: Editora Filhos da África, 2018.

SANTANA, Tiganá. Breves considerações sobre um traduzir negro ou tradução como feitiçaria. Landa, Florianópolis, v. 7, p. 5-16, 2018. Disponível em: https://repositorio.ufsc.br/bitstream/id/ebf57f174593-4dcO-abe4-1d3212e4bf95/1.\%2OTIGANA\%20-\%2OLISTO.pdf. Acesso em: 2 out. 2020.

SANTOS, Antônio Bispo. Colonização, Quilombo: modos e significados. Brasília: INCTI; UnB; INCT; CNPq; MCTI, 2015.

SANTOS, Antonio Bispo. Somos da terra. Piseagrama, Belo Horizonte, n. 12, 2018. Disponível em: https://piseagrama.org/somos-da-terra/. Acesso em: 2 out. 2020.

SILVA, Cidinha da. O velho e a moça. In: SILVA, Cidinha da. Um Exu em Nova York. Rio de Janeiro: Pallas Editora, 2018. p. 27-28.

SIMAS, Luiz Antônio; RUFINO, Luiz. Encantamento (sobre política de vida). Rio de Janeiro: Mórula Editorial, 2020.

XAKRIABÁ, Célia. Amansar o giz. Piseagrama, Belo Horizonte, n. 14, 2020. Disponível em: https://piseagrama.org/amansar-o-giz/. Acesso em: 2 out. 2020. 


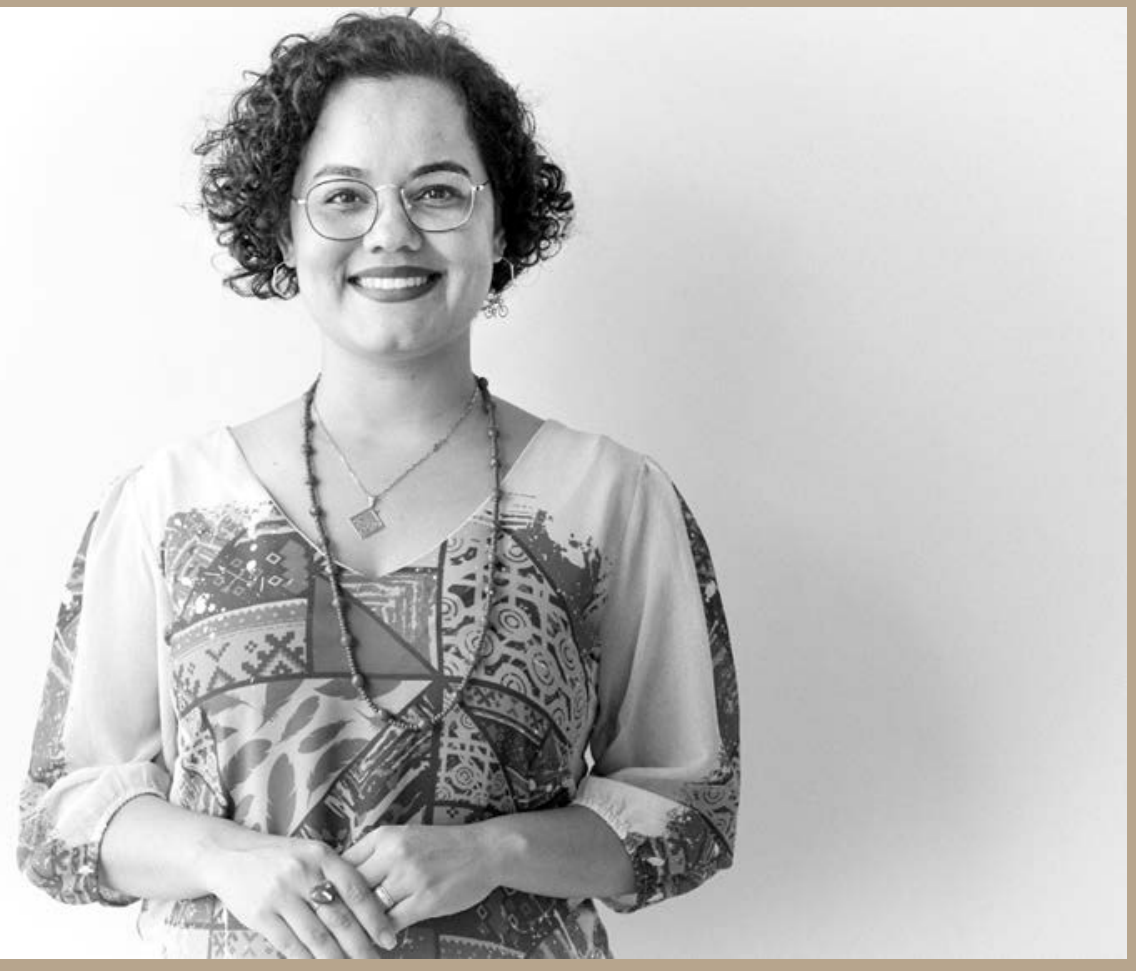




\section{sobre a autora}

Raíssa Félix, nascida no Extremo Sul da Bahia, em Teixeira de Freitas, formou-se em Direito na Faculdade do Sul da Bahia (FASB), como bolsista integral pelo Programa Universidade Para Todos (ProUni), do Governo Federal. É mestra em Ensino e Relações Étnico-Raciais pela Universidade Federal do Sul da Bahia (PPGER/UFSB). "Neta de Maria Dias Cardoso, José Francisco Félix, Rute Pinheiro de Almeida e João Bispo de Almeida. Filha de Cal, que também é Maria, e Zaqueu. Irmã de Priscila e titia de Raíssa. Eu sou aqueles que me deram a vida e me ressignifico pelo labor da terra por eles lavrada sequer a preço de pão. De sonhos e afetos me construo. Sou aquela que vê seu caminho descortinar como o reflexo de uma infinidade de sentimentos e pensamentos com os quais convivo desde que 'me entendo por gente', expressão que se refere ao alcance da minha memória. Sou o meu caminho que se faz, a partir da miudeza da minha individualidade, na tentativa de tornar o mundo socialmente mais justo". 
Colofão

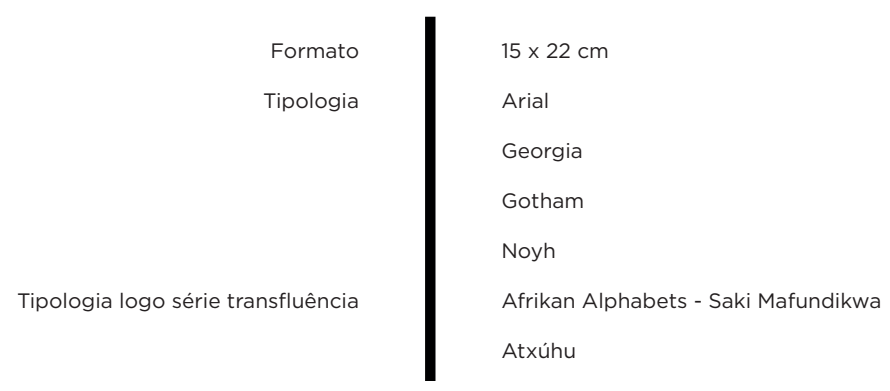


Um percurso de apenas cerca de 40 minutos a partir da minha casa e que me levaria a um universo inimaginável. Volta Miúda me fez revolucionária, porque me fez sentir. Relatar esta caminhada nada mais é do que explicitá-la a partir de um ponto de vista possível. E há muitos. Conceber e internalizar a ideia desta multiplicidade, em contraponto ao vício da dicotomia excludente, já é, em si, um resultado deste percurso de pesquisa. As respostas prontas, mitos, eram ineptas a explicar à mestiça a composição cênica da sua liberdade. Este ser dissonante da coisificação e mercantilização da vida e relações humanas, que advoga por uma liberdade - esta utopia que está lá no horizonte - de formar-se, comportar-se, de sentir. O exercício do sentir se fez prática decolonial e a escuta dos mais velhos um instrumento guia para um encontro. Este livro, como ato memorial, é relato de sentimentos, percepções, pesquisas, análises, conversas com a comunidade quilombola de Volta Miúda.

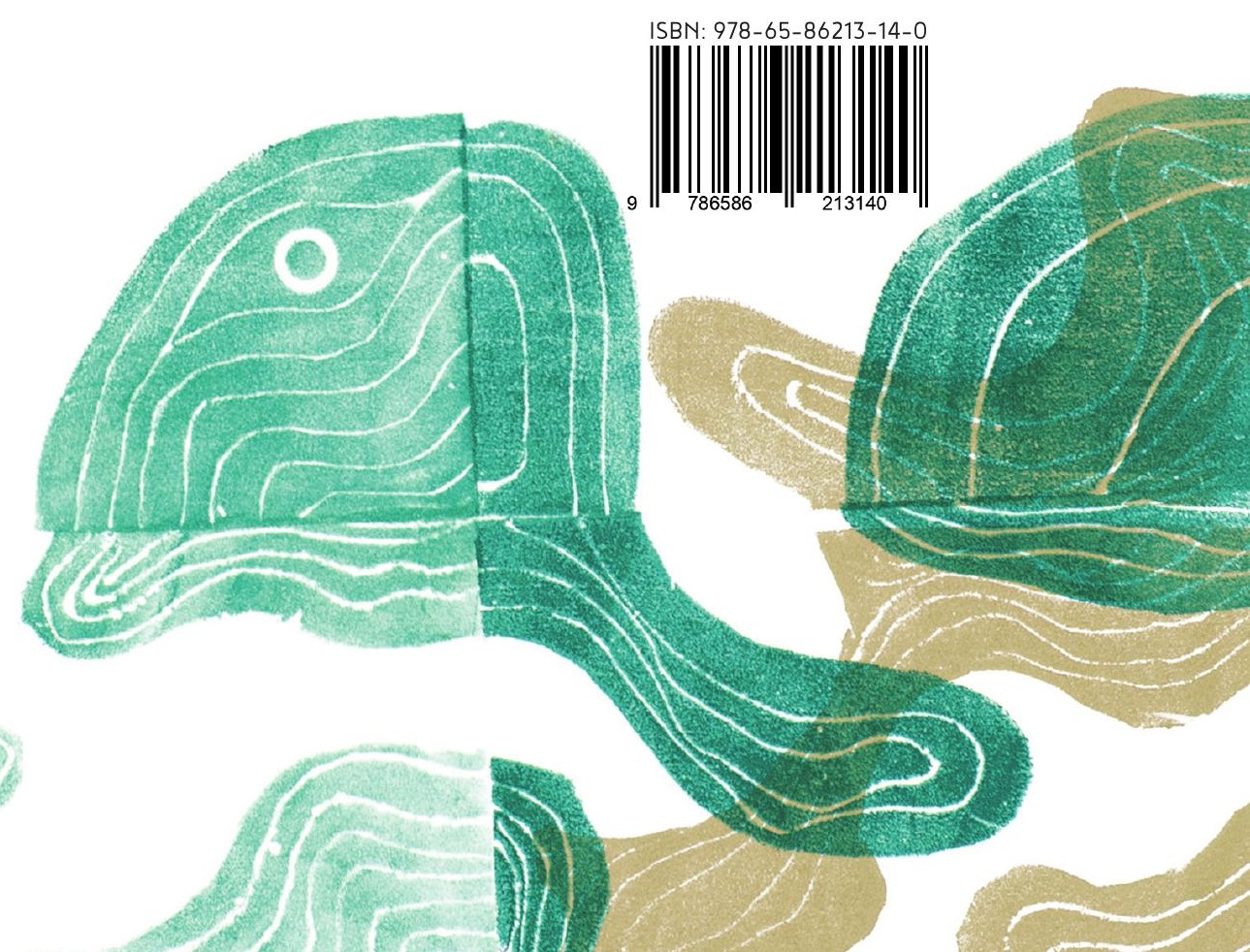

